\title{
Stream ecosystem response to mitigative limestone treatment in acid-impaired, Central Appalachian streams
}

\author{
Sarah Elizabeth McClurg \\ West Virginia University
}

Follow this and additional works at: https://researchrepository.wvu.edu/etd

\section{Recommended Citation}

McClurg, Sarah Elizabeth, "Stream ecosystem response to mitigative limestone treatment in acidimpaired, Central Appalachian streams" (2004). Graduate Theses, Dissertations, and Problem Reports. 2044.

https://researchrepository.wvu.edu/etd/2044

This Thesis is protected by copyright and/or related rights. It has been brought to you by the The Research Repository @WVU with permission from the rights-holder(s). You are free to use this Thesis in any way that is permitted by the copyright and related rights legislation that applies to your use. For other uses you must obtain permission from the rights-holder(s) directly, unless additional rights are indicated by a Creative Commons license in the record and/ or on the work itself. This Thesis has been accepted for inclusion in WVU Graduate Theses, Dissertations, and Problem Reports collection by an authorized administrator of The Research Repository @ WVU. For more information, please contact researchrepository@mail.wvu.edu. 
Stream ecosystem response to mitigative limestone treatment in acid impaired, Central Appalachian streams

\author{
Sarah Elizabeth McClurg
}

\author{
A THESIS \\ Submitted to \\ The Davis College of Agriculture, Forestry, and Consumer Sciences \\ at \\ West Virginia University \\ in partial fulfillment of the requirements \\ for the degree of \\ Master of Science \\ In \\ Wildlife and Fisheries Resources
}

\author{
J. Todd Petty, Ph.D., Co-chair \\ Patricia M. Mazik, Ph.D., Co-chair \\ Janet Clayton, M.S. \\ Wildlife and Fisheries Resources Program \\ Division of Forestry \\ West Virginia University \\ Morgantown, West Virginia \\ 2004
}

Key words: Acid precipitation, benthic, biofilm, Central Appalachian, fish, limestone treatment, macroinvertebrate, stream restoration, water chemistry. 


\begin{abstract}
Stream ecosystem response to mitigative limestone treatment in acid impaired, Central Appalachian streams

Sarah Elizabeth McClurg
\end{abstract}

We quantified water chemistry, primary production, and benthic macroinvertebrate and fish community structure in 20 Central Appalachian streams: 4 acidic streams, 8 naturally circumneutral streams and 8 historically acidic streams treated annually with limestone sand over varying lengths of time. The objective was to determine the extent of chemical and biological recovery and temporal trends in the recovery process of limestone treated streams compared to circumneutral reference conditions in Central Appalachia. Results indicate that the application of limestone sand to acidic streams is effective in fully and immediately recovering some of the chemical and biological characteristics of naturally functioning stream ecosystems such as $\mathrm{pH}$, alkalinity, $\mathrm{Ca}^{2+}, \mathrm{Ca}: \mathrm{H}$ ratios, trout densities and trout young of the year densities. However, recovery of many characteristics is strongly dependent upon spatial proximity to treatment, and still others are never fully recovered. Limestone treatment does not restore several major ions and nutrients $\left(\mathrm{K}^{+}, \mathrm{Mg}^{2+}, \mathrm{Na}^{2+}, \mathrm{NO}_{3}{ }^{-}\right)$or macroinvertebrate taxa richness, biomass, number of acid sensitive macroinvertebrate taxa and fish biomass nor reduce aluminum levels to circumneutral reference conditions. The degree of recovery in macroinvertebrate density, percent acid tolerant and acid sensitive taxa biomass in treated streams depended upon the distance to the upstream treatment location and the degree of recovery in fish species richness depended upon basin area. Full recovery of acid impaired streams will most likely require treatment at the watershed scale including multiple mainstem treatment locations and treating streams as a regional network instead of isolated stream segments. 


\section{Dedication}

I would like to dedicate this effort to my family -whether you claim me or not. Seriously, thank you so much for all of your love and patience. I would not be here if it were not for your support and encouragement. 


\section{Acknowledgments}

I would like to sincerely thank all of my committee members for their endless contributions to this research. Special and gracious thanks to Dr. Todd Petty for his insight and guidance through every step of this project. I would also like to thank our funding sources the West Virginia University Cooperative Fish and Wildlife Research Unit, USGS and West Virginia Division of Natural Resources. I am grateful to the countless number of WVDNR personnel, and WVU undergraduates and graduate students for invaluable field and laboratory assistance especially Ryan Braham and Cindy Sanders. I would like to thank George Siedel and Jason Freund for statistical advice. Finally, I wish to thank all of the wonderful friends I have made during the course of this research adventure. Without you, the all nighters (both in school and on the town) would never have been possible. It has been incredible learning, growing, and most importantly laughing with you all!

THANK YOU! 


\section{Table of Contents}

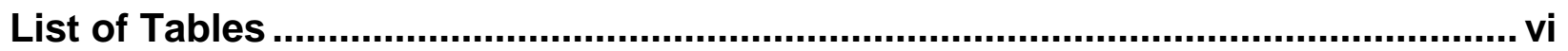

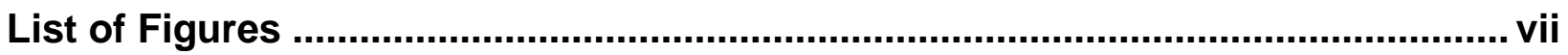

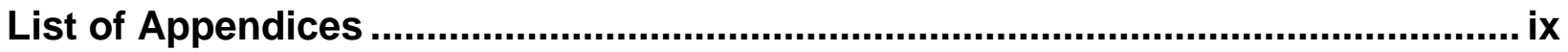



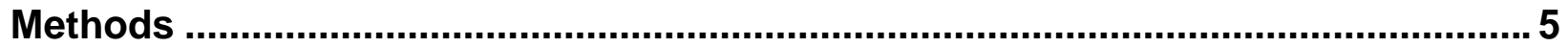

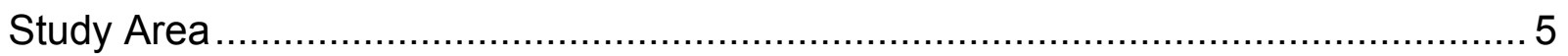

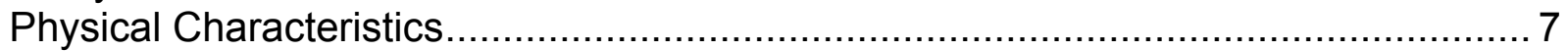

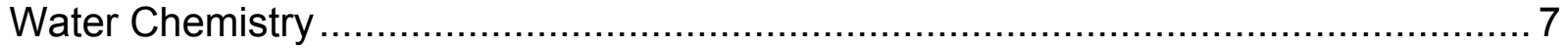

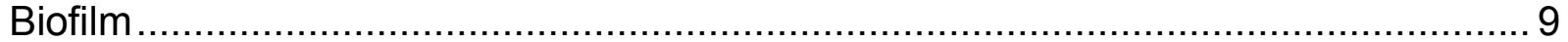

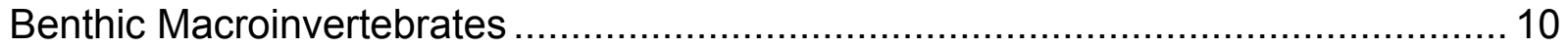

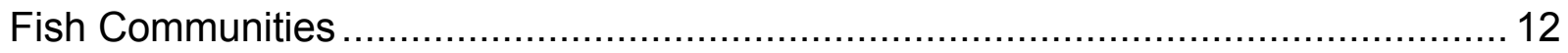

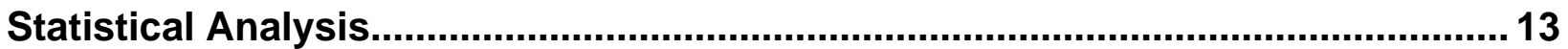



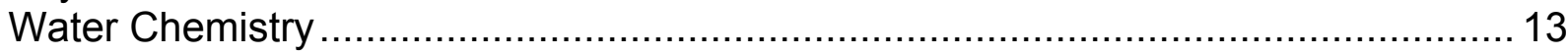

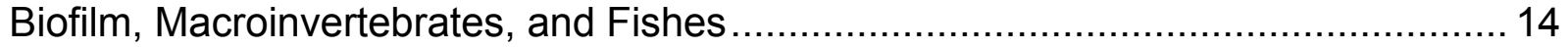

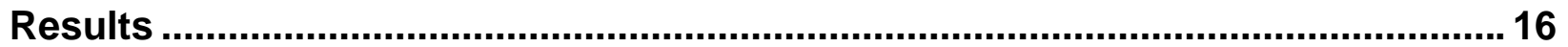

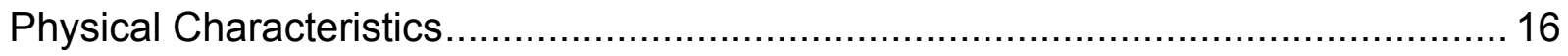

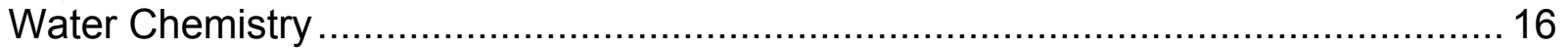

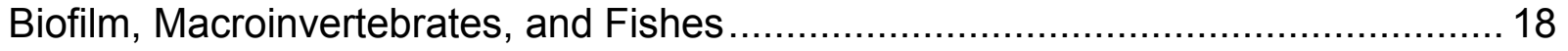

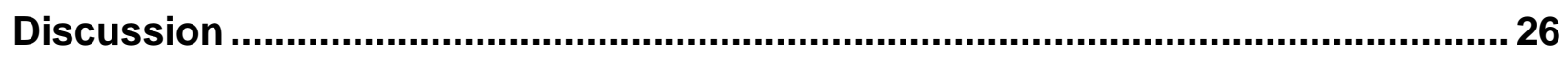

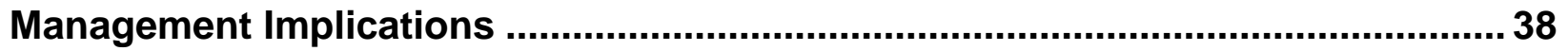

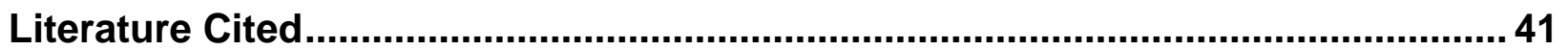




\section{List of Tables}

Table 1. Descriptive characteristics of 20 study streams in the Cheat and Gauley watersheds, WV. Sites are sorted by status $(A=$ acidic, $C=$ circumneutral, and $\mathrm{T}=$ treated with number of years since initial limestone treatment) and basin area.

Table 2. Averaged water quality (SE) parameters by stream status for all seasonal sampling periods. Parameter means sharing a common letter do not significantly differ among stream status ( $p>0.05)$.

Table 3. Summary of overall repeated measures ANOVA for each water chemistry variable including $\mathrm{F}$ values and statistical differences.

Table 4. Aquatic benthic macroinvertebrate community calculations by site, WV 2003.

Table 5. Mean (SE) benthic macroinvertebrate varaibles averaged by stream status. Variable means sharing a common letter do not significantly differ $(p<0.05)$.

Table 6. Summary of ANCOVA statistics for each aquatic benthic macroinvertebrate variable analyzed using a stream status, basin area $\left(\mathrm{km}^{2}\right)$, and relative light model.

Table 7. Aquatic benthic macroinvertebrate FFG calculations by site. 58

Table 8. Results of fish community sampling July 2004 along with stream status ( $A=$ acidic, $C=$ circumneutral, and $T=$ treated with number of years since initial limestone treatment), WV.

Table 9. A summary of the degree of recovery in water chemistry, biofilm, macroinvertebrates, and fishes in acid impaired limestone treated streams compared to circumneutral reference conditions, WV. 


\section{List of Figures}

Figure 1. Study locations and corresponding stream status within the Cheat and Gauley River watersheds, WV. 63

Figure 2. Mean ( $\pm \mathrm{SE})$ temperature, $\mathrm{pH}$, and specific conductance by stream status for April, September, and October, 2003 and April 2004 samples.

Figure 3. Mean ( $\pm \mathrm{SE})$ alkalinity, calcium, and calcium to hydrogen ratios by stream status for April, September, and October, 2003 and April 2004 samples.

Figure 4. Mean ( $\pm \mathrm{SE})$ potassium, magnesium, and sodium by stream status for April, September, and October, 2003 and April 2004 samples.. 66

Figure 5. Mean ( \pm SE) nitrate, sulfate, and chloride by stream status for April, September, and October, 2003 and April 2004 samples..

Figure 6. Mean ( $\pm \mathrm{SE}$ ) total, dissolved, and inorganic monomeric aluminum by stream status for April, September, and October, 2003 and April 2004 samples.

Figure 7. Mean ( \pm SE) total phosphorus, dissolved phosphorus, and phosphate by stream status for April, September, and October, 2003 and April 2004 samples. .. 69

Figure 8. Biofilm biomass as a function of relative light within stream reach. Simple linear regressions were used to fit a line to all samples $<0.5$ and $>0.5$ transformed relative light within the June sampling period.....

Figure 9. Distance from sample location to limestone treatment location as a function of basin area in limestone treated Central Appalachian streams, WV 2003

Figure 10. Benthic macroinvertebrate taxa richness as a function of basin area (A). Treated stream macroinvertebrate taxa richness as a function of distance to treatment location and average macroinvertebrate taxa richness $( \pm 95 \% \mathrm{Cl})$ in circumneutral streams (B).

Figure 11. Total benthic macroinvertebrate density by site as a function of basin area (A). Treated total benthic macroinvertebrate density as a function of distance to treatment location and average macroinvertebrate density $( \pm 95 \% \mathrm{Cl})$ in circumneutral streams (B)

Figure 12. Total benthic macroinvertebrate biomass by site as a function of basin area (A). Treated stream total benthic macroinvertebrate biomass as a function of distance to treatment location and average macroinvertebrate biomass $( \pm 95 \% \mathrm{Cl})$ in circumneutral streams (B). 
Figure 13. Percent acid tolerant macroinvertebrate taxa biomass as a function of basin area (A). Treated stream percent acid tolerant macroinvertebrate taxa biomass as a function of distance to treatment location and average percent acid tolerant macroinvertebrate taxa biomass $( \pm 95 \% \mathrm{Cl})$ in circumneutral streams (B).

Figure 14. Percent acid sensitive macroinvertebrate taxa biomass as a function of basin area (A). Treated stream percent acid sensitive macroinvertebrate taxa biomass as a function of distance to treatment location and average percent acid sensitive macroinvertebrate taxa biomass $( \pm 95 \% \mathrm{Cl})$ in circumneutral streams (B)............... 76

Figure 15. Number of acid tolerant, sensitive, and tolerance unknown taxa averaged by stream status.

Figure 16. Number of acid sensitive taxa present in limestone treated streams as a function of distance to treatment location, WV 2003.

Figure 17. Percent shredder biomass as a function of basin area. A simple linear regression was used to fit a line for all study locals to basin area.

Figure 18. Standard length histogram for all brook trout collected July 2003, WV.

Figure 19. Trout young of the year density as a function of basin area $\left(\mathrm{km}^{2}\right)$. A simple linear regression was used to fit a line to circumneutral streams

Figure 20. Fish species richness as a function of basin area $\left(\mathrm{km}^{2}\right)$ and distance to mainstem $(m)$. Simple linear regressions were used to fit lines to circumneutral streams.

Figure 21. Fish biomass as a function of basin area $\left(\mathrm{km}^{2}\right)$. 83 


\section{List of Appendices}

Appendix I. Water chemistry results by sampling period (1-April 2003, 2-September 2003, 3-October 2003, 4-April 2004) and averaged for each study location............. 84

Appendix II. Acid tolerance classifications for all benthic macroinvertebrate taxa collected.

Appendix III. Benthic macroinvertebrates collected May 2003 from 20 study sites, WV

Appendix IV. Percent benthic macroinvertebrate taxa biomass per site 92 


\section{Introduction}

The acidification of surface waters and subsequent damage to aquatic biota have been well documented in northeastern America, Canada, and Europe (Schindler 1988, Herlihy et al. 1993). This is particularly true in the Central Appalachian Mountains of the eastern U.S., which experiences one of the highest acid loading rates of any area in the nation (Herlihy et al. 1993). The ability of streams in this region to neutralize acidic inputs (acid neutralizing capacity or ANC), often measured in alkalinity $\left(\mathrm{CaCO}_{3} \mathrm{mg} / \mathrm{L}\right)$, is primarily dependent upon the bedrock type the streams flow through, although catchment hydrology has also been found to be a contributing factor (Cresser and Edwards 1987, Sharpe et al. 1987, DeWalle and Swistock 1994, Welsh and Perry 1997).

Many streams in the Central Appalachians with poor buffering capacity are being altered structurally and functionally at all trophic levels due to acidification. The primary causes of these changes are elevated inorganic monomeric aluminum concentrations and reduced pH associated with episodic acidification (Kimmel et al. 1985, Kobuszewski and Perry 1993, Baker et al. 1996, Meegan and Perry 1996, Wigington et al. 1996a). High concentrations of hydrogen and aluminum ions alter ion regulation and gastransfer systems in aquatic biota (Olem 1991). This often leads to improper respiration rates caused by impaired osmoregulation and ion transport or mucus formation on the gills by aluminum hydroxide precipitation (Herrmann and Andersson 1986).

Acidification has been shown to alter both periphyton and macroinvertebrate communities (Burton et al. 1982, Kimmel et al. 1985, Simpson et al.1985, Maurice et al. 1987, Allard and Moreau 1987, Meegan and Perry 1996, Kobuszewski and Perry 1993, 
Likens and Bormann 1995, Bopp 2002). Studies have demonstrated both a reduction and elevation in periphyton biomass and a shift in periphyton community composition to more acidophilic species (Burton et al. 1982, Maurice et al. 1987, Meegan and Perry 1996). Acidification also has been shown to alter feeding mechanisms of primary consumers (Junger and Planas 1993) and reduce overall macroinvertebrate species richness, density, and biomass (Wright et al. 1975, Krueger and Waters 1983, Kimmel et al. 1985, Simpson et al.1985, Allard and Moreau 1987, Kobuszewski and Perry 1993, Likens and Bormann 1995, Bopp 2002). However, some acidified streams may not show a reduction in macroinvertebrate density (Kobuszewski and Perry 1993, Hall 1990) or evenness (Hall 1990) which may be attributed to the reduction or elimination of acid sensitive species and the corresponding proliferation of acid tolerant species (Simpson et al. 1985, Bopp 2002). In fact, invertebrate taxa response to acidic conditions is extremely variable and often species or genus specific (Simpson et al. 1985, Herrmann and Andersson 1986, Hall 1990). Despite this variability, Bopp (2002) found that alkalinity was the primary determinant of stream macroinvertebrate structure and function along a central Appalachian stream continuum at the family level.

Fish communities may be indirectly impacted by acidification through reductions and alteration of food sources (Krueger and Waters 1983). Fish populations also may be directly impacted by acidification through decreased survival rates (Carline et al. 1992, Baker et al. 1996, Van Sickle et al. 1996). Impacts to brook trout (Salvelinus fontinalis) populations are especially severe because they typically inhabit high elevation, small, forested catchments, which have been shown to be exceptionally prone to acidification (Herlihy et al. 1993). In fact, the West Virginia Division of Natural 
Resources (WVDNR) approximates that $25 \%$ of streams within West Virginia that support native brook trout populations have been degraded by acid deposition to some degree (Menendez et al. 1996). Episodic acidification has been found to reduce brook trout abundance and biomass (Baker et al. 1996), and reduce survival rates for all early life history stages (Menendez 1976, Kwain and Rose 1985, Jordahl and Benson 1987, Fiss and Carline 1993, Marschall and Crowder 1996). Newly hatched brook trout larvae have been found to be the most sensitive to reductions in $\mathrm{pH}$ levels compared to other life history stages (Menendez 1976, Kwain and Rose 1985). Increased sensitivity to acidic conditions during this time can lead to brook trout population declines as the time of hatch corresponds with typical episodic events (Fiss and Carline 1993, Baker et al. 1996, Marschall and Crowder 1996).

In order to mitigate the negative biological effects resulting from acid deposition, specifically reduced brook trout fisheries, state agencies in the Central Appalachians use instream applications of limestone sand high in calcium carbonate. The WVDNR began using the addition of limestone sand as a management tool to neutralize acid impaired streams in 1994 (Clayton et al. 1998). In 2002, the WVDNR treated 23 streams with 2500 tons of limestone sand while the West Virginia Department of Environmental Protection (WVDEP) treated 29 streams with 2500 tons of limestone sand (M. Shingleton, WVDNR, personal communication).

Limestone treatment of acid impaired streams has proven extremely beneficial to instream water chemistry (Downey et al.1994, Menendez et al. 1996, Simmons and Cieslewicz 1996) and immediate improvements have been seen post treatment (Weatherely 1988, Olem 1991). General water chemistry trends following limestone 
treatment of acid impacted streams include significantly elevated $\mathrm{pH}$, increased total and dissolved calcium, and reduced total and monomeric aluminum concentrations (Weatherley et al. 1991, Downey et al 1994, Menendez et al.1996, Simmons and Cieslewicz 1996, Clayton et al. 1998).

Improved water quality in acidified streams following limestone treatment has also been shown to beneficially alter macroinvertebrate community structure (Clayton and Menendez 1996), and fish population richness and density (Downey et al. 1994, Menendez et al. 1996, Clayton et al. 1998). In West Virginia, Menendez et al. (1996) observed the colonization of eight fish species, six of which were reproducing, into a stream lacking a resident fish population prior to limestone treatment. In addition, Clayton et al. (1998) saw a rapid expansion of fish populations in five, second-order acidic streams following limestone treatment. However, a few studies have shown no improvement in macroinvertebrate density or diversity or to fish populations post limestone treatment (Simmons and Doyle 1996, Levre and Sharpe 2002).

Despite considerable improvements following instream limestone addition in acid impaired West Virginia streams, questions still remain about the extent to which acid impacted stream ecosystems are entirely restored by limestone addition compared to circumneutral streams. For example, the addition of limestone may fail to mitigate for the loss of base cations (e.g. $\mathrm{Mg}^{2+}$ and $\mathrm{K}^{+}$) from the surrounding watershed soils, or for the continual removal of nutrients such as phosphorus and dissolved organic carbon (DOC) from the water column (Driscoll et al. 1982, Wigington et al. 1996b). Also, biological recovery in treated streams may be affected by colonization rates and reduced genetic variability due to small founding populations (Weatherley 1988). 
Furthermore, temporal trends in the recovery process of acid impaired limestone treated streams in West Virginia are unknown.

Given these uncertainties, the overall objective of this study was to determine the extent of chemical and biological recovery and temporal trends in the recovery process of acid impaired streams treated with limestone sand compared to circumneutral reference conditions in West Virginia. To address this objective, we quantified water chemistry, primary production, and benthic macroinvertebrate and fish community structure in acidic streams, naturally circumneutral streams, and historically acidic streams that have been consistently treated annually with limestone sand over varying lengths of time.

\section{Methods}

\section{Study Area}

Our study was conducted within the Cheat and Gauley River watersheds in the Central Appalachian Mountains of east-central West Virginia. We studied a total of 20 streams: 4 acid impaired (acidic), 8 naturally circumneutral (circumneutral) and 8 historically acidic streams treated annually with limestone sand (treated) (Figure 1). All streams were coldwater systems (instream temperatures never exceeding $22{ }^{\circ} \mathrm{C}$ ) located within predominantly mixed deciduous-coniferous forested catchments within the Monongahela National Forest. Stream basin area, calculated using ArcGIS (Environmental Systems Research Institute), ranged from $0.92 \mathrm{~km}^{2}$ (Little Odey) to $76.98 \mathrm{~km}^{2}$ (Red Creek) (Table 1). ArcGIS also was used to measure the distance from the beginning of each sampled stream reach to the nearest downstream mainstem $(\geq$ $4^{\text {th }}$ order stream) (Osborne and Wiley 1992). 
The number of years since initial limestone treatment varied among treated streams and ranged from 2 to 20 years (Table 1). Two streams, Dogway Fork and Otter Creek, are treated using a mechanized rotary drum system in which limestone aggregate is crushed and released into the stream as a slurry (Zurbuch et al. 1996). The other 6 treated streams are treated through the direct instream application of limestone sand (Clayton et al. 1998). The drum system on Otter Creek ceased to treat in the fall of 2003 and spring of 2004; therefore, Otter Creek was treated with limestone sand during those time periods. Three streams (Dogway Fork, North Fork Cherry River and Red Run) are treated at multiple locations upstream of the study reach. The mainstem Dogway Fork is treated high in the watershed with limestone sand and lower in the watershed with a rotary drum system. One direct tributary is also treated on Dogway Fork between the mainstem sand application point and the rotary drum. The mainstem of the North Fork Cherry River is treated at one location upstream of the study reach; furthermore, three direct tributaries of the North Fork Cherry River upstream of the study reach are also treated with limestone sand. Red Run is treated with limestone sand in the headwaters (North Fork) and downstream of a large acidic tributary (South Fork Red Run) with a similar basin area $\left(9.1 \mathrm{~km}^{2}\right)$ to that of the mainstem Red Run. Our study reach on Red Run was located downstream of this second treatment location. We used ArcGIS to determine the distance from the beginning of each study reach to the furthest upstream limestone application point designed to treat the entire acid load of the study reach in treated streams (Table 1). On Dogway Fork and North Fork Cherry River we considered this location to be the 
mainstem sand application points. On Red Run, we considered this location to be the second application point due to the large acid load from the South Fork Red Run.

\section{Physical Characteristics}

Average wetted width per stream was calculated by measuring wetted width every $10 \mathrm{~m}$. Reach length was determined by multiplying average wetted width by 40 using a set minimum (150 m) and maximum (300 m) reach length (Lyons 1992). We measured canopy cover within each stream reach with a concave spherical densiometer. Four directional readings (upstream, downstream, left bank and right bank) were taken every $10 \mathrm{~m}$ within each study reach (Bopp 2002). All readings were averaged to yield a total average percent canopy cover $( \pm 2.4 \%)$ per stream reach surveyed. We assessed habitat within each stream reach using U.S. Environmental Protection Agency (EPA) rapid visual habitat assessment (RVHA) protocols (Barbour et al. 1999).

\section{Water Chemistry}

A total of 4 water chemistry samples were collected: April, September, and October, 2003 and April, 2004. During each sampling period, we collected three water samples per site with the exceptions of sampling period 1 (April 2003) and sampling period 3 (October 2003) in which Red Creek and Upper Second Fork were not sampled, respectively. Red Creek was not sampled in April 2003 due to delays in study site selection and Upper Second Fork was not sampled in October 2003 due to equipment constraints. One $250 \mathrm{~mL}$ water sample was filtered using a Nalgene polysulfone filter holder and receiver with mixed cellulose ester membrane disc filters with a $0.45 \mu \mathrm{m}$ pore size. Filtered samples were immediately treated with $2 \mathrm{~mL} 2 \%$ nitric acid to bring 
the $\mathrm{pH}$ below 2. Filtered samples were used to analyze dissolved variables. An unfiltered $250 \mathrm{~mL}$ grab sample was also collected and treated with $2 \mathrm{~mL} 2 \%$ nitric acid. This unfiltered acidified sample was used for the analysis of total cations and anions. The third sample was an unfiltered $472 \mathrm{~mL}$ grab sample. This sample was used to analyze alkalinity and inorganic monomeric aluminum. All samples were kept on ice after collection, and stored in the laboratory at $4{ }^{\circ} \mathrm{C}$ until analysis could be completed at the National Research Center for Coal and Energy (NRCCE) at West Virginia University (WVU).

The following chemical variables were analyzed: calcium $\left(\mathrm{Ca}^{2+}\right)$, magnesium $\left(\mathrm{Mg}^{2+}\right)$, potassium $\left(\mathrm{K}^{+}\right)$, sodium $\left(\mathrm{Na}^{2+}\right)$, chloride $\left(\mathrm{Cl}^{-}\right)$, nitrate $\left(\mathrm{NO}_{3}{ }^{-}\right)$, sulfate $\left(\mathrm{SO}_{4}{ }^{2-}\right)$, total (TP) and dissolved phosphorus (DP), phosphate $\left(\mathrm{PO}_{4}{ }^{-}\right)$, alkalinity (alk), total aluminum (T_Al), dissolved aluminum (D_Al), and inorganic monomeric aluminum (M_Al) according to EPA standard methods (EPA 1991). Calcium-to-hydrogen ionic ratios (Ca:H) were calculated using instream $\mathrm{pH}$ measurements and $\mathrm{Ca}^{2+}$ results from the NRCCE. Ca:H ratios have been shown to be an effective index for determining suitable water chemistry for fish survival and the effectiveness of limestone mitigation (Porcella et al. 1990, Brown and Skeffington 1992, Clayton et al. 1998). Alkalinity in the form of $\mathrm{CaCO}_{3}$ was analyzed using an auto titrator method (EPA 1991; method 310.1). Cations were measured using inductively coupled plasma optical emission spectroscopy (ICPOES) (EPA 1991; method 200.7). Anions such as $\mathrm{Cl}^{-}, \mathrm{NO}_{3}{ }^{-}, \mathrm{SO}_{4}{ }^{2-}$, and $\mathrm{PO}_{4}{ }^{-}$were analyzed using a flow injection analyzer according to EPA method numbers 325.3, 353.2, 375.2, and 365.1, respectively (EPA 1991). Monomeric inorganic aluminum was 
analyzed using a cation exchange through a strongly acidic exchange resin followed by ICP-OES (EPA 1991; method 200.7).

Temperature $\left({ }^{\circ} \mathrm{C}\right)$, specific conductance $(\mu \mathrm{s} / \mathrm{cm})$, and $\mathrm{pH}$ were measured in the field with a YSI 600 XL Multi-Parameter Water Quality Monitor (YSI Incorporated, Yellow Springs, $\mathrm{OH})$ during each water chemistry sample $(N=4)$ with the exception of Little Odey $(\mathrm{N}=3)$ due to equipment constraints. Discharge was calculated at each site during each sampling season using a Marsh-McBirney Flo-Mate (Marsh-McBirney Incorporated, Frederick, MD).

\section{$\underline{\text { Biofilm }}$}

We collected biofilm samples in June and August, 2003. We used a simple random sampling technique to sample eleven rocks contained within riffle habitat in each stream reach surveyed. Using modified EPA-EMAP standard protocols (Hill 1998) for periphyton sampling in erosional habitat as a template, we scraped an $18.5 \mathrm{~cm}^{2}$ area on each of the 11 rocks per stream and combined these into one composite sample per stream reach. This composite sample was measured to the nearest $0.1 \mathrm{~mL}$ and 25 to $50 \mathrm{~mL}$ of the sample was then filtered through a Whatmann glass fiber filter $(0.7 \mu \mathrm{m}$ pore size) and kept dark and on ice for transport back to the lab where it was kept at 4 ${ }^{\circ} \mathrm{C}$ until analyzed. The filters were placed in numbered aluminum weigh boats and dried at $100{ }^{\circ} \mathrm{C}$ for 24 hours, cooled in a dessicator, and weighed to the nearest $0.1 \mathrm{mg}$. The biofilm samples were then dried for another 5 hours, cooled, and re-weighed twice to make sure all moisture was removed from the sample yielding dry mass. Samples were then volatized in a muffle furnace at $500{ }^{\circ} \mathrm{C}$ for 6 hours and weighed to the nearest 0.1 $\mathrm{mg}$ after cooling in a dessicator. The weight of the residual ash after volatization plus 
the filter was then subtracted from the weight of the dry mass plus the filter to calculate an ash-free dry mass (AFDM) for each sample. We divided the AFDM (mg) by the proportion of the sample analyzed, then divided by the total area sampled per stream to yield amount of biofilm present per unit area of stream $\left(\mathrm{mg} / \mathrm{cm}^{2}\right)$ which was used as an estimate of the biomass of primary producers (Meegan and Perry 1996).

ex: $\quad 50 \mathrm{~mL}$ filtered out of $250 \mathrm{~mL}$ composite sample $=0.2$ (proportion analyzed) $18.5 \mathrm{~cm}^{2}$ sampled per rock * 11 rocks $=203 \mathrm{~cm}^{2}$ (total area) AFDM (mg) / $0.2 / 203 \mathrm{~cm}^{2}=$ biofilm biomass $\left(\mathrm{mg} / \mathrm{cm}^{2}\right)$

\section{Benthic Macroinvertebrates}

We sampled benthic macroinvertebrate communities in May 2003. We decided to sample macroinvertebrates once in the spring based upon previous studies showing smaller seasonal variation in macroinvertebrate communities compared to spatial variation (Reece and Richardson 1998) even within a $4 \mathrm{~km}$ stretch of stream and among streams with similar physical and chemical characteristics (Mathew et al. 1991, Death 1995). Furthermore, Bopp (2002) found that relative macroinvertebrate community patterns were consistent across seasonally sampling within a Central Appalachian stream continuum. Five collections were made in targeted riffles distributed throughout each stream reach using a modified Hess sampler $\left(0.10 \mathrm{~m}^{2}, 250 \mu \mathrm{m}\right.$ mesh net) for all study locals (Rosemond et al. 1992). Stones contained within the Hess sampler frame were thoroughly scrubbed clean up to a depth of $\sim 10 \mathrm{~cm}$. The composite sample $(5$ Hess collections) was then elutriated through a $250 \mu \mathrm{m}$ mesh sieve and preserved onsite with $95 \%$ ethanol. Samples were brought back to WVU and dyed using Rose Bengal solution to facilitate sample processing (Williams and Williams 1974). 
Benthic samples were sorted using a combination of $1 \mathrm{~mm}$ and $250 \mu \mathrm{m}$ sieves. All macroinvertebrates retained in the $1 \mathrm{~mm}$ sieve were identified to the lowest practical taxonomic level using Merritt and Cummins (1996) and Wiggins (1998). Oligocheates and Nematomorphs were identified to order, Ephemeroptera, Plecoptera, and Trichoptera (EPT) were identified to genera and the remaining taxa collected were identified to the family level. The $250 \mu \mathrm{m}$ samples were sub-sampled using a Folsom Phytoplankton Splitter (Wildco, Buffalo, NY) and $12.5 \%$ of this sample was identified as above. Subsamples were multiplied by 8 and added to the $1 \mathrm{~mm}$ samples for an overall stream reach macroinvertebrate community estimate. A subset of individual identifications was verified by Janet Clayton (WVDNR) and through reference collections at WVU. An ocular micrometer was used to measure all head capsule widths to the nearest $0.1 \mathrm{~mm}$. We then used regression equations to convert head capsule widths to dry mass (DM) (Benke et al. 1999) in order to estimate relative macroinvertebrate biomass per stream $\left(\mathrm{mgDM} / \mathrm{m}^{2}\right)$. Oligocheates and Nematomorphs were removed and analyzed separately due to incomplete specimens with indistinguishable anterior ends. These two orders were combined per site, dried and weighed (mgDM) according to the methods outlined above for drying and weighing biofilm samples and added to macroinvertebrate biomass estimates $\left(\mathrm{mgDM} / \mathrm{m}^{2}\right)$.

Benthic macroinvertebrate density and biomass were calculated by totaling the number of individuals $(\mathrm{N})$ and $\mathrm{mgDM}$ collected within each stream reach divided by area of stream sampled $\left(\mathrm{m}^{2}\right)$, for all taxa at the lowest taxonomic level identified. Stream area sampled was estimated by multiplying average wetted width by reach length. All macroinvertebrate taxa collected were grouped according to their level of acid tolerance 
(acid tolerant, acid sensitive, or tolerance unknown) using Rosemond et al. 1992, Clayton and Menendez (1996), and Simmons and Doyle (1996) (Appendix II). Percent acid tolerant and acid sensitive taxa biomass and number of acid tolerant and acid sensitive species per stream were then calculated. All aquatic benthic macroinvertebrates were also assigned to one of the following functional feeding groups (FFG): collector/filterer, collector/gatherer, scraper, shredder, predator or unknown (Appendix III) using Merritt and Cummins (1996) and Bopp (2002) at the lowest taxonomic level identified. Percent biomass for all FFG was then calculated for each stream reach.

\section{Fish Communities}

We conducted fish community sampling in July 2003 in collaboration with the WVDNR. A one-pass electrofishing procedure modified from EPA-EMAP protocols outlined by McCormick et al. (2001) was used to sample each stream reach using a backpack electrofisher (Smith-Root, DC, 60hz, 400-600 V, Vancouver, WA) and a combination of dip nets and a portable seine. All fish collected were anesthetized in clove oil (20\% ethanol) and measured for standard length $( \pm 1 \mathrm{~mm})$ and weight $( \pm 0.1 \mathrm{~g})$. Game fish were measured individually. Non-game fish were sorted into species batches and group weighed. Minimum and maximum standard length $(\mathrm{mm})$ for each batch was measured. All fish were returned to their approximate location of capture after recovery from the anesthetic. Density $\left(\mathrm{N} / \mathrm{m}^{2}\right)$ and biomass $\left(\mathrm{g} / \mathrm{m}^{2}\right)$ were calculated to estimate relative stream fish productivity. 


\section{Statistical Analysis}

\section{Physical Characteristics}

Percent relative light within each stream reach was estimated by subtracting average percent canopy cover from 100. We then transformed the proportion of relative light (arcsine square root) within each stream reach to approximate normality. An analysis of variance (ANOVA) was then used to test the hypothesis that there were no differences in transformed relative light levels among the three stream types: acidic (A), circumneutral $(\mathrm{C})$ and treated $(\mathrm{T})$. We also used ANOVA to test the hypothesis that there were no differences in total habitat assessment scores and temperature among stream types. Stream basin area $\left(\mathrm{km}^{2}\right)$ was log transformed $[\ln (x+1)]$ in order to approximate normality for all subsequent analyses. All analyses were run at an alpha level of 0.05 set a priori.

\section{Water Chemistry}

We transformed $[\ln (x+1)]$ water chemistry concentrations to approximate normality. Minimum detection limit values were used for analysis if results were below detectable range. To analyze stream status and seasonal effects on water chemistry, a repeated measures ANOVA was used to test the hypothesis that there were no differences among streams of different status, no differences among sampling periods (April, September, and October, 2003 and April, 2004), and no stream status * sampling period interactions for each water quality parameter analyzed. Furthermore, ANOVA was also used to test the hypothesis that there were no differences in water chemistry parameters averaged across sampling periods among streams of different status. We used a simple linear regression to determine if there was a time since initial treatment 
effect on averaged water chemistry variables in treated streams. Scheffe's Method was used for all post hoc pairwise comparisons.

Biofilm, Macroinvertebrates, and Fishes

Biofilm biomass $\left(\mathrm{mg} / \mathrm{cm}^{2}\right)$ was log transformed $[\ln (x+1)]$ to approximate normality. A simple linear regression was used to determine the relationship between biofilm biomass and relative light within each stream reach. ANOVA was used to test the hypothesis that there was no difference in biofilm biomass between sampling periods and among stream status. Also, we used a simple linear regression to determine if there was a time since initial treatment effect on biofilm biomass for both sampling periods in treated streams.

Benthic macroinvertebrate density $\left(\mathrm{N} / \mathrm{m}^{2}\right)$ and biomass $\left(\mathrm{mgDM} / \mathrm{m}^{2}\right)$ were log transformed $[\log (\mathrm{x})]$ and macroinvertebrate percent data was transformed (arcsine square root of proportion) to approximate normality. Decapoda $(\mathrm{N}=48)$ were removed from all analyses, because they have been shown to significantly increase the variance in stream macroinvertebrate biomass estimates (Miller 1985). Macroinvertebrates of terrestrial origin identified including Araneae $(\mathrm{N}=2)$, Coleoptera Carabiidae $(\mathrm{N}=2), \mathrm{C}$. Curculionidae $(\mathrm{N}=1)$, C. Elateridae $(\mathrm{N}=1)$, Diptera Drosophilidae $(\mathrm{N}=1)$ Homoptera Coccoidae $(\mathrm{N}=1)$, Hymenoptera Formicidae $(\mathrm{N}=2)$, and Lepidoptera $(\mathrm{N}=1)$, were also removed from all statistical analyses and instream density and biomass estimates. Also, Collembola $(\mathrm{N}=1)$, Copepoda $(\mathrm{N}=2)$, Hydracarina $(\mathrm{N}=8)$, and Hemiptera Gerridae $(\mathrm{N}=2)$ were removed from biomass estimates and analyses only, due to lack of biomass / head capsule width regressions for these taxa. 
Percent biomass of acid tolerant and acid sensitive macroinvertebrate taxa were calculated by dividing total biomass for each tolerance level within each stream reach by total site biomass multiplied by 100 . Percent FFG biomass per stream reach was also calculated in this manner. All percent data was transformed (arcsine square root of proportion) to approximate normality. Simple linear regressions were used to determine relationships between basin area $\left(\mathrm{km}^{2}\right)$, relative light, distance to treatment location $(\mathrm{m})$, and number of years since initial limestone treatment with benthic macroinvertebrate richness, density $\left(\mathrm{N} / \mathrm{m}^{2}\right)$, biomass $\left(\mathrm{mgDM} / \mathrm{m}^{2}\right)$, percent acid tolerant and acid sensitive biomass, number of acid tolerant and acid sensitive taxa per reach, and percent FFG biomass. ANOVA was used to test the hypothesis that there were no differences in macroinvertebrate community variables among stream types. Also, we used analysis of covariance (ANCOVA) to determine the effects of stream status, basin area $\left(\mathrm{km}^{2}\right)$, and light on all macroinvertebrate variables with basin area and light as covariates. Due to the high variability inherent in benthic macroinvertebrate sampling, statistical relationships with $p<0.1$ were considered significant.

Simpler linear regressions were used to determine the effects of distance to mainstem $(m)$, distance to treatment location $(m)$, and number of years since initial limestone treatment on fish species richness, density $\left(\mathrm{N} / \mathrm{m}^{2}\right)$, trout density, and trout young of the year (yoy) density. ANOVA was used to test the hypothesis that there were no differences in fish community variables among streams of different status. 


\section{Results}

\section{Physical Characteristics}

Temperature was significantly affected by stream status $(F=3.13$, d.f. $=2,74$, $p=0.05)$; however, significant differences among stream status were not detected in the post hoc pairwise comparison (Table 2). Nevertheless, circumneutral streams were significantly warmer than acidic and treated streams in April 2003 and significantly warmer than treated streams in April 2004 (Figure 2a). All study streams did however have temperatures consistently below $20^{\circ} \mathrm{C}$ (Figure 2a). Mean canopy cover did not differ significantly among streams of different status $(F=1.20$, d.f. $=2,17, p=0.327)$. Percent canopy cover within stream reach ranged from 34\% (Red Creek) to 96\% (Little Black Fork) (Table 1). Eighteen out of the 20 sample sites had an optimal RVHA score (166-200) while two, Red Creek and South Fork of Red Creek, had suboptimal scores of 154 and 147, respectively (Table 1). Nevertheless, we found no significant difference in RVHA score among stream status $(F=2.33$, d.f. $=2,19, p=0.13)$.

\section{Water Chemistry}

We found significant seasonal variation in the concentration of several water chemistry variables, including $\mathrm{pH}$, calcium, Ca:H ratios, potassium, magnesium, sodium, total phosphorus, phosphate, total and dissolved aluminum, nitrate, sulfate, and specific conductance (Table 3). For all streams sampled, average $\mathrm{pH}$ was found to be highest in October and lowest in April, 2004 (Figure 2b), whereas average calcium levels were highest in September and lowest in April 2003 (Figure 3b). Average potassium levels were consistently lowest in April, 2003 (Figure 4a), whereas average nitrate levels were consistently highest in April, 2004 (Figure 5a). Sulfate 
concentrations were highest in the two spring samples compared to September and October with 2003 averages higher than those in 2004 (Figure 5b). Average dissolved and total aluminum levels were also highest in the spring compared to the September and October samples, with the exception of the highly variable total aluminum concentrations of acidic streams in September (Figures 6a,b).

Numerous water chemistry parameters were found to be influenced by stream status (Tables 2, 3). Specifically, we found that $\mathrm{pH}$, calcium, and Ca:H ratios, were significantly higher in both circumneutral and treated streams compared to acidic streams (Table 2, Figures $2 \mathrm{~b}, 3 \mathrm{~b}$,and $\mathrm{c}$ ). Average $\mathrm{pH}$ ranged from $4.74-5.01$ in acidic streams, $6.42-7.30$ in circumneutral streams, and $6.23-7.46$ in treated streams (Appendix I). Average alkalinity across sampling periods was found to be significantly higher in circumneutral and treated streams compared to acidic streams; however, this trend was not consistent within individual sampling periods most likely due to the high variability in alkalinity levels in circumneutral and treated streams (Table 2, Figure 3a). Alkalinity ranged from $0-20 \mathrm{mg} / \mathrm{L} \mathrm{CaCO}_{3}$ in circumneutral streams and from $1.74-24$ $\mathrm{mg} / \mathrm{L} \mathrm{CaCO}_{3}$ in treated streams with the treated Dogway Fork having the second highest average alkalinity $\left(18.26 \mathrm{mg} / \mathrm{L} \mathrm{CaCO}_{3}\right)$ next to the circumneutral Rattlesnake Run (24.63 mg/L $\left.\mathrm{CaCO}_{3}\right)$ out of all sites sampled (Appendix I).

Circumneutral streams had significantly higher specific conductance than acidic streams (Table 2). This trend was not consistent within sampling periods, however, and may be attributed to the high variability of specific conductance in circumneutral streams (Figure 2c). Also, no differences in specific conductance were detected between circumneutral and treated streams and between treated and acidic streams when 
averaged across sampling periods (Table 2). Potassium, magnesium, sodium, and nitrate were significantly higher in circumneutral streams compared to both acidic and treated streams when averaged across sampling periods (Table 2). However, this trend was variable within sampling periods (Figures 4a-c, 5a). Total and dissolved aluminum levels were significantly lower in circumneutral streams compared to both acidic and treated streams when averaged across sampling periods (Table 2) and within all sampling periods (Figure 6a,b).

Treated streams sampled $>3 \mathrm{~km}$ downstream from treatment location had significantly higher $\mathrm{pH}(\mathrm{F}=8.99$, d.f. $=1,6, \mathrm{p}=0.024)$ and marginally higher $\mathrm{Ca}: \mathrm{H}$ ratios $(F=4.2$, d.f. $=1,6, p=0.086)$ compared to streams sampled $<2 \mathrm{~km}$ downstream from treatment location. $\mathrm{pH}$ and $\mathrm{Ca}: \mathrm{H}$ ratios in streams sampled $>3 \mathrm{~km}$ from treatment averaged $7.08(\mathrm{SE}=0.17)$ and 5,930 (SE = 2,489), respectively, while $\mathrm{pH}$ and $\mathrm{Ca}: \mathrm{H}$ in streams sampled $<2 \mathrm{~km}$ from treatment averaged $6.50(\mathrm{SE}=0.097)$ and 798 (SE = 233), respectively. Statistical trends for all other water chemistry variables based on distance to treatment location were not detected. The number of years since initial limestone treatment had no detectable effect on any water chemistry variable analyzed for treated streams $\left(R^{2}\right.$ ranged from $<0.0001$ to 0.3 , $p$ value ranged from 0.99 to 0.16 ).

\section{Biofilm, Macroinvertebrates, and Fishes}

Stream status had no significant effect on biofilm biomass in neither the June nor August sample (June: $F=0.37$, d.f. $=2,17, p=0.695$; August: $F=0.81$, d.f. $=2,17, p=0.459$ ). However, biofilm biomass was strongly influenced by season and canopy cover (Figure 8). Specifically, biofilm biomass was significantly higher in June than August ( $F=21.51$, d.f. $=1,39, p<0.001)$ and biofilm biomass tended to increase with increasing light levels 
(June sample only) (Figure 8). In particular, June biofilm biomass was positively correlated with light levels in streams with $>80 \%$ canopy cover (transformed relative light $<0.5$ ), but did not influence primary production in streams receiving higher light inputs (>0.5) (Figure 8b). Despite the lack of a stream status effect on biofilm production, it should be noted that the highest biofilm biomass was measured in a circumneutral stream, whereas the lowest was observed in a treated stream (Figure 8b).

Treated stream basin area was highly correlated with distance to treatment location $\left(R^{2}=0.72, p=0.008\right)$ (Figure 9). However, distance to treatment location often explained more of the variation in treated stream macroinvertebrate variables compared to basin area (e.g. treated stream macroinvertebrate density, biomass, percent acid tolerant taxa etc.). Therefore, distance to treatment location was used to describe variation of macroinvertebrate communities in treated streams.

We identified and measured a total of 12,419 macroinvertebrates and found 70 different macroinvertebrate taxa. Circumneutral streams consistently had higher macroinvertebrate taxa richness compared to acidic and treated streams, with the exception of Dogway Fork (a treated stream) (Table 4, Figure 10). Mean taxa richness in circumneutral streams was found to be significantly higher than both acidic and treated streams, while no difference was detected between acidic and treated taxa richness post hoc (Table 5). Overall, basin area and relative light levels had no detectable influence on macroinvertebrate taxa richness (Table 6). Treated stream taxa richness tended to increase with an increase in basin area $\left(R^{2}=0.28\right)$; however this trend was not statistically significant $(p>0.1)$ (Figure 10a). The positive correlation 
between treated stream taxa richness and distance from treatment location $\left(R^{2}=0.52\right)$ was statistically significant, however $(p=0.045)$ (Figure 10b).

Total benthic macroinvertebrate densities $\left(\mathrm{N} / \mathrm{m}^{2}\right)$ were significantly influenced by stream status and basin area (Table 6). Circumneutral streams had higher benthic macroinvertebrate total densities than treated streams and higher densities than acidic streams, although not statistically significant (Table 5). On average, total macroinvertebrate density in acidic streams was higher than treated streams and lower than circumneutral streams; however, acidic and treated densities were not found to be statistically different post hoc (Table 5).

Total site benthic macroinvertebrate density exhibited a positive correlation with basin area for all stream status; however, the correlation between treated stream macroinvertebrate density and basin area was the only relationship found to be statistically significant $\left(R^{2}=0.755, p=0.005\right)$ (Figure 11a). This strong positive correlation was also seen for treated stream macroinvertebrate density and distance to treatment location $\left(R^{2}=0.83, p=0.002\right)$ (Figure 11b). Treated streams Otter Creek, Big Rocky Run, Dogway Fork, and North Fork of Cherry all sampled $>3 \mathrm{~km}$ downstream of treatment location had macroinvertebrate densities within the $95 \%$ confidence interval (Cl) for circumneutral streams (Figure 11b). Whereas all treated streams sampled $<2$ $\mathrm{km}$ downstream from treatment location had drastically reduced densities compared to circumneutral streams (Figure 11b). Overall, stream status, basin area, and light explained $72 \%$ of the variation in total benthic macroinvertebrate density for all study locations (Table 6). 
As with total benthic macroinvertebrate densities, total macroinvertebrate biomass $\left(\mathrm{mgDM} / \mathrm{m}^{2}\right)$ was significantly influenced by steam status and basin area (Table 6). On average, circumneutral streams had significantly higher total macroinvertebrate biomass compared to both acidic and treated streams (Table 5). Treated and acidic streams had similar total benthic macroinvertebrate biomass with the exception of Dogway Fork which had a total macroinvertebrate biomass more similar to circumneutral streams (Table 4, Figure 12a). Treated streams did, however, exhibit high variation in total stream biomass ranging from 71 to $1670 \mathrm{mgDM} / \mathrm{m}^{2}$ (Table 4) and with a percent coefficient of variation of 116.34 compared to percent coefficient of variations of 18.1 and 38.64 in acidic and circumneutral streams, respectively. Both circumneutral and treated stream total macroinvertebrate biomass was positively related to basin area; however, only circumneutral stream total biomass was significantly correlated at the $p<0.1$ level (Figure 12a). Treated stream macroinvertebrate biomass was, however, significantly correlated with distance to treatment location $\left(R^{2}=0.56, p=\right.$ 0.004 ) (Figure 12b). Although relative light levels seemed to contribute slightly to the overall predictive power of the model set for benthic macroinvertebrate total biomass, statistically significant trends were not detected (Table 6). Percent biomass for each taxa identified at the lowest possible taxonomic level for each site was calculated and can be viewed in Appendix IV.

Percent tolerant taxa biomass was found to be strongly correlated with stream status (Table 6). Acidic streams had close to $100 \%$ tolerant taxa biomass, circumneutral streams ranged from $30 \%$ (Little Black Fork) to $75 \%$ (Little Odey), and treated streams were in between these two ranging from $40 \%$ (North Fork Cherry) to 93 
\% (Crouch Run) (Table 4). A pairwise post hoc comparison showed significant differences between all three stream classes with acidic streams having the highest percent acid tolerant taxa biomass followed by treated then circumneutral streams. (Table 5, Figure 13a). Percent tolerant taxa biomass was found to be significantly and negatively correlated with stream basin area in both circumneutral and treated streams; however, basin area did not influence percent tolerant taxa biomass in acidic streams (Table 6, Figure 13a). The negative correlation between percent tolerant taxa and basin area in circumneutral streams appears to be driven by Little Odey, which had a large percent acid tolerant taxa biomass $(75 \%)$ compared to all other circumneutral streams and was the smallest stream sampled (Figure13a). The acid tolerant stonefly Yugus and caddisfly Rhyacophila comprised approximately $30 \%$ of Little Odey's total macroinvertebrate biomass.

Distance to treatment location explained $81 \%$ of the variation in percent tolerant taxa biomass for treated streams $(p=0.0024)($ Figure 13b). Treated streams sampled $>$ $3 \mathrm{~km}$ downstream from treatment location had percent tolerant taxa biomass similar to circumneutral streams, while treated streams sampled $<2 \mathrm{~km}$ downstream from treatment location had percent tolerant taxa biomass much greater than circumneutral streams and more similar to acidic streams (Figure 13b). Overall, stream status, basin area, and relative light explained $77 \%$ of the variation in benthic macroinvertebrate percent tolerant taxa biomass for all study locations (Table 6).

Percent acid sensitive macroinvertebrate taxa biomass results support the findings outlined above for acid tolerant taxa biomass. Acidic streams had $0 \%$ acid sensitive taxa biomass, whereas circumneutral and treated streams ranged from $11-$ 
$66 \%$ and $0-51 \%$, respectively (Table 4 ). Average percent acid sensitive taxa biomass was found to be significantly higher in circumneutral streams compared to both treated and acidic streams and significantly higher in treated streams compared to acidic streams (Table 5). We found a negative correlation between percent acid sensitive taxa biomass and relative light (Table 6). However, percent acid sensitive taxa biomass was positively correlated with basin area in both circumneutral and treated streams (Figure 14a). Again, Little Odey appears to be the most influential factor for this trend seen in circumneutral streams (Figure 14a). Treated streams consistently had lower percent acid sensitive taxa biomass for stream size compared to circumneutral streams (Figure 14a). As with percent acid tolerant taxa biomass, treated stream percent acid sensitive taxa biomass was highly influenced $\left(R^{2}=0.96, p<0.0001\right)$ by distance to treatment location (Figure 14b). Treated streams sampled $>3 \mathrm{~km}$ downstream from treatment location had percent acid sensitive taxa biomass more similar to circumneutral streams than treated streams sampled $<2 \mathrm{~km}$ downstream from treatment location which all had percent acid sensitive taxa biomass $(<10 \%)$ much lower than circumneutral streams and more similar to acidic streams (Figure 14b).

The number of acid tolerant and acid sensitive macroinvertebrate taxa present within stream reach was found to be highly influenced by stream status (Table 6). On average, acidic and circumneutral streams had significantly higher numbers of acid tolerant taxa than treated streams while circumneutral streams had significantly higher numbers of acid sensitive taxa compared to both acidic and treated streams (Table 5 , Figure 15). Distance from treatment location significantly accounted for $59 \%$ of the variability in the number of acid sensitive macroinvertebrate taxa in treated streams 
$(p=0.026)$ (Figure 16). Treated streams sampled $<2 \mathrm{~km}$ downstream of treatment location ranged from 0 - 3 acid sensitive taxa present while those sampled $>3 \mathrm{~km}$ downstream ranged from 4 - 11 (Figure 16). The North Fork Cherry River and Dogway Fork were the only treated streams found to have similar numbers of acid sensitive taxa compared to circumneutral streams (Table 4, Figure 16).

Acid sensitive macroinvertebrate species found in circumneutral streams that were not found in any of the treated stream reaches include the mayfly Ephemera, and the caddisflies Chimarra and Cheumatopsyche (Appendix IV). Two acid sensitive species found consistently in circumneutral streams (the mayfly Acentrella and the stonefly Pteronarcys) were also found only in the treated Dogway Fork (Appendix IV). Acid sensitive species such as the mayfly Paraleptophlebia, caddisflies of the family Hydroptilidae and the caddisfly Dolophilodes found in circumneutral streams were also found in Dogway Fork plus North Fork Cherry River, Otter Creek, and North Fork Cherry River, respectively (Appendix IV). Acid sensitive species such as the mayflies Baetis, Drunella, Ephemerella, and the caddisfly Ceratopsyche found in circumneutral streams were also found in treated streams, but only in those treated streams that were sampled $>3 \mathrm{~km}$ downstream from treatment location (Appendix IV). These treated streams also supported more diversity in the mayfly family Heptageniidae (Appendix IV). The stonefly family Perlidae was not found in any of the acidic reaches, but was found in the majority of both circumneutral and treated stream reaches.

Percent biomass for all FFG was found to be highly variable within stream status, stream size, and relative light levels (Table 7). In fact, there was no stream status effect detected for any FFG (Table 6). However, percent shredder and biomass per site was 
found to be negatively correlated with basin area $\left(\mathrm{km}^{2}\right)$ (Table 6, Figure 17) whereas percent scraper biomass per site was found to be negatively correlated with relative light (Table 6). Further, time since initial treatment had no detectable effect on any macroinvertebrate community variable discussed above $\left(R^{2}\right.$ ranged from 0.13 to $0.26, p$ value ranged from 0.38 to 0.19 ).

Fish were collected in all stream reaches except for the acidic North Fork of Cranberry (Table 8). Using a standard length frequency distribution developed from all brook trout collected at all study locations, we considered young of the year brook trout to be $\leq 75 \mathrm{~mm}$ (Figure 18). This brook trout yoy size class was consistent with findings by Lamothe (2002) and ongoing research in this region (Petty, unpublished data). This size class was then used to represent young of the year for all trout species collected. We found a strong negative correlation between basin area $\left(\mathrm{km}^{2}\right)$ and trout yoy density $\left(\mathrm{N} / \mathrm{km}^{2}\right)$ in circumneutral streams (Figure 19). Treated streams had trout yoy densities similar to and greater than trout yoy densities found in circumneutral streams given basin area while trout yoy were only found in one acidic stream (South Fork Red Creek) in extremely low numbers (Figure 19). Overall, stream status had no effect on trout densities $(F=2.52$, d.f. $=2,17, p=0.11)$ or trout yoy densities $(F=2.37$, d.f. $=2,17, p=0.124)$.

Fish species richness was not affected by stream status $(F=2.36$, d.f. $=2,17$, $p=0.124)$. However, fish species richness was highly correlated with basin area in circumneutral streams exhibiting a strong positive trend (Figure 20a). Fish species richness in smaller treated streams was found to be similar to richness found in circumneutral streams; however, larger treated steams had fewer fish species than was expected based upon circumneutral conditions (Figure 20a). A negative correlation 
between fish species richness and the distance from sampling location to the confluence of the mainstem was detected in circumneutral streams although not statistically significant (Figure 20b). Treated streams had fish species richness values similar to and greater than circumneutral streams given distance to the mainstem with the exception of North Fork of Cherry, which had depressed fish species richness based upon this model (Figure 20b).

We found an overall stream status effect on fish biomass $(F=13.17$, d.f. $=2,17$, $p=0.0004)$ and a pairwise post hoc comparison indicated that treated streams supported significantly less productive fish populations than circumneutral streams but significantly more productive fish populations than acidic streams (Figure 21). The treated Dogway Fork was an exception to this trend however, as it supported a fish population similar in productivity to average circumneutral conditions (Figure 21).

\section{Discussion}

Our results indicate that limestone treatment of acidic streams in West Virginia is effective in fully recovering some of the chemical and biological characteristics of naturally functioning stream ecosystems. However, recovery of many characteristics is strongly dependent upon spatial proximity to treatment, and still others are never fully recovered (Table 9). Specifically, we found that limestone mitigation immediately and fully restores $\mathrm{pH}$, alkalinity, $\mathrm{Ca}^{2+}$, Ca:H ratios, trout densities and trout yoy densities in acidic streams to circumneutral reference conditions (Table 9). However, limestone treatment does not appear to restore several major ions and nutrients $\left(\mathrm{K}^{+}, \mathrm{Mg}^{2+}, \mathrm{Na}^{2+}\right.$, $\mathrm{NO}_{3}{ }^{-}$) or macroinvertebrate taxa richness, biomass, number of acid sensitive macroinvertebrate taxa and fish biomass nor reduce aluminum levels to circumneutral 
reference conditions (Table 9). Furthermore, the degree of recovery in macroinvertebrate density, percent acid tolerant and acid sensitive taxa biomass in acid impaired limestone treated streams depended upon the distance to the upstream treatment location and the degree of recovery in fish species richness depended upon basin area (Table 9).

\section{Characteristics that Fully Recover}

The full recovery of $\mathrm{pH}$, alkalinity, calcium, $\mathrm{Ca}: \mathrm{H}$ ratios and reproducing trout populations in limestone treated streams was consistent with other studies conducted in this region (Weatherley et al. 1991; Downey et al. 1994; Menendez et al. 1996, Clayton et al. 1998). Despite lethal aluminum levels (discussed below) in several treated streams, high calcium concentrations from the application of limestone allowed for the full recovery of trout populations. High levels of calcium have been shown to reduce the toxic effects of elevated aluminum levels in fish bioassays (Brown 1983, Peterson et al. 1989, Ingersoll et al. 1990).

Young of the year trout were found in all circumneutral and treated streams with densities being highest in streams of smaller basin area. Lamothe (2002) found that streams with a basin area $<3 \mathrm{~km}^{2}$ supported $>80 \%$ of spawning activity in a Central Appalachian watershed. Only one stream, Little Odey, had a basin area of that size in this study; however, successful reproduction (summer trout yoy) occurred in numerous streams with greater basin areas. Lamothe (2002) also found successful reproduction to be limited to streams with alkalinity levels $>5-10 \mathrm{mg} / \mathrm{L} \mathrm{CaCO}_{3}$. All acidic streams in this study were below that threshold and the lack of trout yoy within these stream reaches reflect this finding. However, 3 circumneutral streams (Big Run, Gandy Run, 
and Grants Branch) and 4 limestone treated streams (Otter Creek, Crouch Run, First Fork, and Red Run) had average alkalinity concentrations $<5 \mathrm{mg} / \mathrm{L} \mathrm{CaCO}_{3}$ but had reproducing trout populations. We conclude that average $\mathrm{Ca}: \mathrm{H}$ ratios $\geq 10$ is a better water quality indicator for reproducing brook trout populations as all circumneutral and treated streams with reproducing trout populations had $\mathrm{Ca}: \mathrm{H}$ ratios $\geq 10$. These findings support suggestions made by Clayton et al (1998) that Ca:H ratios $\geq 10$ are sufficient enough to maintain reproducing brook trout populations.

\section{Characteristics that Never Recover}

Numerous studies have shown that the loss of base cations (i.e. $\mathrm{Ca}^{2+}, \mathrm{Mg}^{2+}$, $\left.\mathrm{Na}^{2+}, \mathrm{K}^{+}\right)$from soils of acidified watersheds is a significant factor influencing surface water chemistry (DeWalle and Swistock 1994, Likens et al. 1996, Wigington et al. 1996b, Lawrence et al. 1999). Consequently, it is not surprising that Appalachian streams treated with limestone sand do not recover base cation concentrations other than $\mathrm{Ca}^{2+}$. This may be important biologically, because $\mathrm{Mg}^{2+}, \mathrm{Na}^{2+}$, and $\mathrm{K}^{+}$are essential elements for cellular processes such as ion transport, enzyme activation and control of protein conformation in all organisms (Bowen 1966, Hynes 1970, Phipps 1976). Nevertheless, these nutrients are not considered limiting in most stream ecosystems (Dodds 2002).

Nitrogen and phosphorus, however, potentially are limiting nutrients in lotic ecosystems (Pringle 1987, Peterson et al. 1993, Rosemond et al. 1993, Tank and Webster 1998). Differences in phosphorus levels among stream status were not detected; however, phosphate levels in all streams sampled were extremely low $(<5$ :g/L) (Rosemond et al. 1993) which is typical of forested streams in the eastern U.S 
(Omernik 1977). Nitrate, on the other hand, was found to be significantly depressed in limestone treated streams compared to circumneutral reference conditions. Nitrogen is also an essential nutrient for aquatic biota as significant amounts are needed for amino acid and protein formation (Bowen 1966, Hynes 1970, Phipps 1976). Therefore, it is possible that reduced nitrate concentrations coupled with low phosphate concentrations in treated streams could depress productivity levels compared to circumneutral streams.

Perhaps most significant was the finding that limestone treatment was not effective at reducing aluminum levels to circumneutral reference conditions. Dissolved aluminum concentrations exceeded aquatic biota chronic impairment levels according to West Virginia water quality standards $(>0.087 \mathrm{mg} / \mathrm{L})$ in a number of acidic and treated stream reaches. Also, inorganic monomeric aluminum concentrations were $>0.06$ $\mathrm{mg} / \mathrm{L}$, a level thought to be unsuitable for the survival and reproduction of many fish species (Baker et al. 1996), in several acidic streams and a few treated streams. In contrast, dissolved and inorganic monomeric aluminum concentrations never surpassed toxic levels in any circumneutral stream. Furthermore, it is important to note that streams were not sampled on ascending limbs during high flow events which have been found to facilitate the greatest depressions in $\mathrm{pH}$ and elevations in aluminum levels (Baker et al. 1996); therefore, minimum $\mathrm{pH}$ and maximum aluminum concentrations were most likely not detected in our study.

Macroinvertebrate taxa richness, biomass, number of acid sensitive macroinvertebrate taxa and fish biomass also were never fully recovered in limestone treated streams compared to circumneutral reference conditions, with the exception of Dogway Fork (a treated stream), regardless of distance to upstream treatment location. 
In fact, macroinvertebrate taxa richness and biomass within limestone treated streams more closely resembled depressed levels found in acidic stream reaches. It is important to note, however, that greater distance to upstream treatment location did positively affect these macroinvertebrate variables, but full recovery was never achieved.

Limestone treatment did allow for the recolonization of several acid sensitive macroinvertebrate taxa, a finding that supports those of Clayton and Menendez (1996). However our study demonstrates that the abundance of intolerant taxa remained low in treated streams with the exception of Dogway Fork. Based upon results from this study, the following macroinvertebrate taxa appear to be good indicators of low acid impairment (i.e. high $\mathrm{pH}$ and $\mathrm{Ca}: \mathrm{H}$ ratios) in circumneutral and treated Central Appalachian streams: the mayflies Baetis, Acentrella, Drunella, Ephemerella, Ephemera, and Paraleptophlebia, the caddisflies Ceratopsyche, Cheumatopsyche, Diplectrona, Chimmara and Dolophilodes and the stonefly families Perlidae and Pteronarcyidae.

Unlike any other limestone treated stream in this study, Dogway Fork had macroinvertebrate taxa richness, biomass, number of acid sensitive macroinvertebrate taxa, and fish biomass comparable to circumneutral streams. This stream also had the second highest average alkalinity and highest $\mathrm{pH}$ of all study locations. This improvement in water quality and consequent improvement in Dogway's macroinvertebrate and fish communities may be attributed to either 1) the effectiveness of its limestone doser or 2) its two mainstem treatment locations or a combination there of. Dogway Fork is treated high in the watershed using the instream application of 
limestone sand and lower in the watershed with the use of a rotary drum system (Menendez et al. 1996). If the recovery of Dogway Fork's ecosystem was attributed solely to the effectiveness of the limestone doser, we would anticipate recovery in Otter Creek to be similar to that seen in Dogway Fork. However, Otter Creek had approximately $50 \%$ of the macroinvertebrate biomass, 7 fewer acid sensitive macroinvertebrate taxa, and reduced fish species richness and biomass compared to Dogway Fork. The full recovery of water chemistry, macroinvertebrate communities, and fish populations within Dogway Fork demonstrates that limestone treatment can be effective at completely restoring acid impaired stream ecosystems. However, it still remains unclear why Dogway Fork was the exception and not the rule. Treating the North Fork Cherry River at a second mainstem location may help to clear up this uncertainty. The North Fork Cherry River and Dogway Fork are similar in stream size and available habitat and are both treated at multiple locations; however, Dogway Fork is treated at multiple locations within the mainstem and has much more fully recovered ecosystem than the North Fork Cherry River $\underline{\text { Recovery Dependent Upon Spatial Location }}$

Recovery of several important measures of ecological condition in acidic streams was strongly dependent on spatial proximity to limestone treatment. Variables influenced by spatial position include macroinvertebrate density, percent acid tolerant and acid sensitive biomass and fish species richness. Although basin area and distance to treatment location were highly correlated $\left(R^{2}=0.72\right)$, distance to treatment location was a better predictor of macroinvertebrate community recovery. All macroinvertebrate variables analyzed in this study were positively influenced with 
increasing distance from treatment location. Limestone treated streams sampled $>3$ $\mathrm{km}$ downstream from treatment locations consistently had greater macroinvertebrate taxa richness, density, and biomass, and lower percent acid tolerant biomass, and increased numbers of acid sensitive taxa than those sampled $<2 \mathrm{~km}$ downstream from treatment location. However, only macroinvertebrate density, and percent acid tolerant and acid sensitive macroinvertebrate taxa biomass in treated streams sampled $>3 \mathrm{k}$ downstream from treatment location were fully recovered to circumneutral reference conditions.

Levre and Sharpe (2002) also found that improvements to macroinvertebrates in a treated stream in Massachusetts depended upon the downstream location of the collection. In their study, macroinvertebrate communities were negatively affected 300 $\mathrm{m}$ downstream of treatment location, but improved $1.6 \mathrm{~km}$ from the point of treatment application compared to an acidic control reach. Our results indicate a slightly greater distance $(>2 \mathrm{~km})$ is necessary for macroinvertebrate community improvements following limestone treatment. It is important to note that First Fork, McGee Run, and Crouch Run (all sampled $<2 \mathrm{~km}$ from treatment location) were sampled as far away from treatment location as possible ( $<65 \mathrm{~m}$ from the confluence with a mainstem) while Red Run (also sampled $<2 \mathrm{~km}$ from treatment location) was sampled approximately $7.7 \mathrm{~km}$ from the confluence of its mainstem. Consequently, it is possible that macroinvertebrate communities in Red Run were more fully recovered further downstream (> $2 \mathrm{~km}$ downstream from treatment location).

The incomplete recovery of macroinvertebrate communities in limestone treated streams, especially those sampled $<2 \mathrm{~km}$ downstream of treatment location, may be 
influenced by dispersal mechanisms, water chemistry variability, and/or increases in sedimentation from limestone sand additions. The downstream dispersal of macroinvertebrates has been found to be important to colonization rates (Fenoglio et al. 2002). Therefore, the colonization of acid sensitive species into treated stream reaches may be limited because the upstream communities of limestone treated streams are acidophilic (Clayton and Menendez 1996). However, a recent study conducted by Bradley and Ormerod (2002) comparing macroinvertebrate communities in limestone treated streams with circumneutral streams showed that the low occurrence of acid sensitive species in treated streams was most likely caused by highly variable water quality (periods of low $\mathrm{pH}$ ). This pattern was also observed in our study as treated stream reaches sampled $>3 \mathrm{~km}$ downstream from treatment location had higher $\mathrm{pH}$, $\mathrm{Ca}: \mathrm{H}$ ratios, and numbers of acid sensitive species compared to those sampled $<2 \mathrm{~km}$ downstream. An increase in sediments may also impact macroinvertebrate communities in treated streams sampled $<2 \mathrm{~km}$ downstream from treatment location. Increased sedimentation has been shown to lead to reductions in macroinvertebrate abundances, and structurally and functionally altered communities (Tebo 1955; Lamberti and Berg 1995; Vouri and Joensuu 1996). However, Menendez et al. (1996) did not see any changes in instream sediment chemistry $2.5 \mathrm{~km}$ downstream of the Dogway Fork doser. Therefore, it is likely that our study reaches were far enough downstream from treatment locations $(>1 \mathrm{~km})$ to avoid the potential negative impacts of increased sedimentation on macroinvertebrate communities seen approximately $300 \mathrm{~m}$ downstream from treatment location (Menendez et al. 1996, Levre and Sharpe 2002). 
Our results indicate that limestone treatment is effective at restoring expected fish species richness based upon circumneutral conditions in smaller basin area streams; however, larger treated streams had fewer fish species than was expected based upon the circumneutral stream model. This trend may be due to lack of connectivity within watersheds as limestone treated streams are often isolated within acid impaired watersheds (Freund 2004). Also, summer 2003 was an extremely wet year for West Virginia and high flows may have affected sampling efficiency in larger stream reaches. We also found that fish species richness decreased with increasing distance to a mainstem confluence supporting findings that local fish diversity is influenced by proximity to larger, more specios streams (Gorman 1986, Osborne and Wiley 1992).

\section{No Stream Status Effect}

Studies have shown both an increase (Burton et al. 1982) and decrease (Meegan and Perry 1996) in periphyton biomass in streams impacted by acid deposition. We found no differences in biofilm biomass between circumneutral, limestone treated, or acidic streams. This was most likely due to the proliferation of acidophilic species (Burton et al. 1982, Maurice et al. 1987, Meegan and Perry 1996), although we did not assess the taxonomic composition of the biofilm. Therefore, it is possible that differences in primary productivity among stream status were present but were not detected because we did not gather biofilm community information nor obtain detailed measures of productivity over the course of the year.

Periphyton biomass has been shown to vary seasonally (Ledger and Hildrew 1998, Francouer et al. 1999). Specifically, studies have shown that primary productivity 
peaks in the spring and early summer when light intensities are highest before canopy development followed by a subsequent reduction and minimum levels in late summer (McIntire and Phinney 1965, Ledger and Hildrew 1998, Hill et al. 2001). Our results support these findings as biofilm biomass was significantly reduced between early and late summer samples. We also found a positive correlation between relative light and biofilm biomass in low light stream reaches in support of findings that primary production in streams with dense riparian zones are strongly affected by light levels (Fisher and Likens 1973, Vannote et al. 1980, Hill et al. 2001). Therefore, the reduction of primary productivity from early to late summer was most likely due to the reduction of relative light entering stream reaches caused by riparian zone leaf out. However, it is possible that grazing by macroinvertebrates also contributed to the reduction in biofilm biomass between samples in this study (Rosemond et al. 1993, Wellnitz et al. 1996). Also, we found no significant relative light effect on primary productivity in high light streams regardless of stream status indicating that these stream reaches are not light limited but may be nutrient limited (Stockner and Shortreed 1978, Elwood et al. 1981, Grimm and Fisher 1986, Peterson et al. 1993, Bothwell et al.1994).

\section{Temporal Trends in Recovery}

We conclude that the number of years an acid impaired steam is treated with limestone sand does not contribute to the overall recovery of its ecosystem. Treatment on First Fork, Crouch Run, and Dogway Fork began $>10$ years ago; however, these streams had extremely different macroinvertebrate communities. Both First Fork and Crouch Run were dominated by acid tolerant taxa and had extremely depressed macroinvertebrate densities and biomass compared to Dogway Fork. Also, comparing 
temporal variation in treatment with macroinvertebrate communities in Big Rocky Run, McGee Run, Crouch Run and Red Run also provides evidence for immediate partial recovery of macroinvertebrate communities in treated streams (Clayton and Menendez 1996) and lack of temporal influence. Big Rocky run has been treated with limestone sand for only 2 years and it too had greater macroinvertebrate density and biomass and a larger percent biomass and taxa number of acid sensitive species such as the mayflies Baetis and Ephemerella, and the stonefly family Perlidae compared to McGee Run, Crouch Run, Red Run, and First Fork which have all been treated for $\geq 7$ years. Finally, temporal trends in the recovery process of fish populations in limestone treated streams were not detected indicating an immediate recovery of fishes following limestone treatment supporting findings by Menendez et al. (1996) and Clayton et al. (1998) in West Virginia.

$\underline{\text { Acidification impacts }}$

Our results support findings of reduced macroinvertebrate species richness and biomass in acid impacted stream reaches (Wright et al. 1975, Krueger and Waters 1983, Kimmel et al. 1985, Simpson et al.1985, Allard and Moreau 1987, Kobuszewski and Perry 1993, Likens and Bormann 1995, Bopp 2002). Loss of larger acid sensitive species such as the stoneflies of the families Perlidae and Pteronarcyidae within acidic stream reaches studied most likely contributed to the reduction in macroinvertebrate biomass as these families made up a large percentage of circumneutral stream biomass. Results of this study also support findings by Kobuszewski and Perry (1993) and Hall (1990) that macroinvertebrate densities in acid impacted streams are not reduced due to the proliferation of acid tolerant taxa (i.e. Chironimidae, Leuctridae, 
Ameletidae etc.). Dominant macroinvertebrate taxa within acidic streams in our study were similar to those found in other acidic Appalachian streams (Clayton and Menendez 1996, Rosemond 1992, Bopp 2002) with the exception of the stonefly family Perlodidae, which Bopp (2002) found to be acid-intolerant in a Central Appalachian river continuum.

During the spring samples, streams studied experienced reductions in $\mathrm{pH}$, and increases in nitrate, sulfate, and total and dissolved aluminum concentrations. These water chemistry trends are typical of episodic acidification (Wigington et al. 1996) indicating that the circumneutral and treated streams studied may still be susceptible to acidification during high flows. Furthermore, due to the high percentage of macroinvertebrate biomass comprised of acid tolerant species in Little Odey compared to other circumneutral streams sampled, this stream should probably be considered moderately acidic and highly vulnerable to continued acid deposition.

The River Continuum Concept

Our results both support and contradict predictions outlined by the RCC (Vannote et al. 1990). Macroinvertebrate biomass was positively correlated with basin area in circumneutral streams supporting predictions of the RCC (Vannote et al. 1990) and findings by Grubaugh et al. (1996) and Bopp (2002). Also, supporting predictions outlined by the RCC (Vannote et al. 1980) and findings by Horwitz (1978), Belliard and Tales (1997) and Freund (2004), fish species richness in circumneutral and limestone treated streams increased with increasing basin area. However, we also found that macroinvertebrate taxa richness was not correlated with basin area contradicting RCC predictions (Vannote et al. 1990) and findings by Minshall et al. (1983), Grubaugh et al. 
(1996) and Bopp (2002) therefore supporting compensation rather than summation of taxa with a progression downstream.

Herlihy et al. (1993) reported that the large majority of chronically or episodically acidic streams in the Appalachians are located in small, high elevation, forested watersheds with poor base cation soils. Therefore, we recognize that trends detected between basin area and macroinvertebrate and fish population variables in both circumneutral and treated streams may be partially influenced by acid impairment levels.

\section{Management Implications}

Studies of surface waters in the Northeastern United States have indicated that despite declining rates of acidic deposition over the last few decades, acidified streams have shown little to no improvements in this area (Likens et al. 1996, Driscoll et al. 1998). Likens et al. (1996) and Lawrence et al. (1999) attribute this lack of improvement to depletions of soil base cation concentrations caused by acidic deposition. Given these findings, streams currently impacted by acidic deposition in the Central Appalachians are not likely to recover and streams in this area with poor base cation concentrations in their surrounding soils are liable to become acidified in the future. Therefore, steps to mitigate the negative impacts of acidic deposition on instream aquatic biota will continue to be important in the Central Appalachians for some time.

Results from this study demonstrate that limestone treatment of acid impacted streams in the Central Appalachians is effective in recovering some elements of naturally functioning stream ecosystems. However, full recovery potential of acid 
impaired streams will probably require remediation actions directed at the scale of the entire watershed. We suggest treating all streams (especially small streams) as high in the watershed as possible in order to reach full recovery potential of aquatic benthic macroinvertebrate communities. It may also be beneficial to treat acid impacted streams at more than one mainstem location (i.e. Dogway Fork) in order to increase contact time with the limestone. We recommend treating the North Fork Cherry River in this manner to determine whether the doser or multiple mainstem treatment locations on Dogway Fork is the driving force for ecosystem recovery in that stream. We also suggest developing watershed management plans in which acid impaired watersheds are treated as a network to allow for the movement and full recolonization potential of fish populations.

Future research in acidic stream mitigation might include the addition of nonreplaceable nutrients to limestone sand such as nitrogen and phosphorus. The instream addition of nitrogen and phosphorus in tandem has been shown to increase microbial activity, biofilm biomass, and grazer biomass in a second order forested Appalachian stream (Elwood et al. 1981, Rosemond et al. 1993). Although, nitrate concentrations in both circumneutral and treated streams were not low enough to be considered limiting $(<50: \mathrm{g} / \mathrm{L})$, studies have shown that limiting nutrients can vary year to year within the same system and that with the addition of phosphorus alone, systems can switch to become nitrogen limited (Elwood et al. 1981, Rosemond et al. 1993). Furthermore, stream systems have shown the greatest response to nitrogen and phosphorus enrichment in tandem compared to the addition of these nutrients independently (Stockner and Shortreed 1978, Rosemond et al. 1993). Increasing 
nitrogen (as $\mathrm{NaNO}_{3}$ and $\mathrm{NH}_{4} \mathrm{Cl}$ ) and phosphorus $\left(\right.$ as $\mathrm{K}_{2} \mathrm{HPO}_{4}$ ) to 10 times the annual average concentration of these nutrients in treated streams may increase biofilm and grazer biomass (Rosemond et al. 1993). Potential increases in productivity at lower trophic levels in treated streams could propagate to higher trophic levels leading to increased fish growth rate and overall fish biomass (Peterson et al. 1993). However, due to anthropogenic practices such as fossil fuel combustion, fertilizer production and application, and waste disposal, the over enrichment of nitrogen has become a ubiquitous problem in lotic ecosystems which ultimately impacts our estuaries and oceans (Howarth et al. 1996, Carpenter et al. 1998). Therefore, the benefits (e.g. potential increases in productivity) of adding nitrogen and phosphorus to limestone treated streams must be weighed against the contribution to a much larger problem. Also, full ecosystem recovery was achieved in Dogway Fork without the use of additional nutrients; therefore, limestone treatment practices similar to those seen in Dogway Fork should be implemented before experiments with nutrient additions are conducted. 


\section{Literature Cited}

Allard, M. and G. Moreau. 1987. Effects of experimental acidification on a lotic macroinvertebrate community. Hydrobiologia 144:37-50.

Baker, J.P., J. Van Sickle, C.J. Gagen, D.R. DeWalle, W.E. Sharpe, R.F. Carlene, B.P. Baldigo, P.S. Murdoch, D.W. Bath, W.A. Kretser, H.S. Simonin, and P.J. Wigington. 1996. Episodic acidification of small streams in the northeastern United States: effects on fish populations. Ecological Applications 6(2):422-437.

Barbour, M.T., J. Gerritsen, B.D. Snyder, and J.B. Stribling. 1999. Rapid Bioassessment Protocols for Use in Streams and Wadeable Rivers: Periphyton, Benthic Macroinvertebrates and Fish, Second Edition. EPA 841-B-99-002. U.S. Environmental Protection Agency; Office of Water; Washington, D.C.

Belliard, J., P. Boet, and E. Tales. 1997. Regional and longitudinal patterns of fish community structure in the Seine river basin, France. Environmental biology of fishes 50(2):133-147.

Benke, A.C., A.D. Huryn, L.A. Smock, and J.B. Wallace. 1999. Length-mass relationships for freshwater macroinvertebrates in North America with particular reference to the southeastern United States. Journal of North American Benthological Society 18(3):308-343.

Bopp, J.A. 2002. Combined effects of water chemistry, canopy cover, and stream size on benthic macroinvertebrates along a central Appalachian stream continuum. Master's Thesis. West Virginia University. Morgantown, WV.

Bothwell, M.L., D.M.J. Sherbot, and C.M. Pollock. 1994. Ecosystem response to solar ultraviolet-B radiation: influence of trophic-level interactions. Science 265:91100.

Bowen, H.J.M. 1966. Trace elements in biochemistry. Academic Press, New York, NY.

Bradley, D.C. and S.J. Ormerod. 2002. Long-term effects of catchment liming on invertebrates in upland streams. Freshwater Biology 47:161-171.

Brown, D.J.A. 1983. Effect of calcium and aluminum concentrations on the survival of brown trout (Salmo trutta) at low pH. Bulletin of Environmental Contamination and Toxicology 30:582-587.

Brown, D.J.A. and R.A. Skeffington. 1992. Timescales of recovery from acidification: Implications of current knowledge for aquatic organisms. Environmental Pollution 77(2-3): 227-234. 
Burton, T.M., R.M. Stanford, and J.W. Allan. 1982. The effects of acidification of stream ecosystems. Pages 209-235 in F.M.D'Itri (editor) Acid precipitation, effects on ecological systems. Ann Arbor Science Publishers, Ann Arbor, Ml.

Carline, R.F., D.R. DeWalle, W.E. Sharpe, B.A. Dempsey, C.J., Gagen, and B. Swistock. 1992. Water chemistry and fish community responses to episodic stream acidification in Pennsylvania, USA. Environmental Pollution 78:45-48.

Carpenter, S., N.F. Caraco, D.L. Correll, R.W. Howarth, A.N. Sharpley, and V.H. Smith. 1998. Nonpoint pollution of surface waters with phosphorus and nitrogen. Issues in Ecology 3:1-12.

Clayton, J.L., E.S. Dannaway, R. Menendez, H.W. Rauch, J.J. Renton, S.M. Sherlock, and P.E. Zurbuch. 1998. Application of limestone to restore fish communities in acidified streams. North American Journal of Fisheries Management 18:347360.

Clayton, J.L. and R. Menendez. 1996. Macroinvertebrate responses to mitigative liming of Dogway Fork, West Virginia. Restoration Ecology 4(3):234-246.

Cresser, M.S. and A. Edwards. 1987. Acidification of freshwaters. Cambridge University Press, New York, NY.

Death, R.G. 1995. Spatial patterns in benthic invertebrate community structure: products of habitat stability or are they habitat specific. Freshwater Biology 33:455-467.

DeWalle, D.R. and B.R. Swistock. 1994. Causes of episodic acidification in five Pennsylvania streams on the northern Appalachian Plateau. Water Resources Research 30(7):1955-1963.

Downey, D.M., C.R. French, and M. Odom. 1994. Low cost limestone treatment of acid sensitive trout streams in the Appalachian mountains of Virginia. Water, Air, and Soil Pollution 77(1):49-77.

Driscoll, C.T., G.E. Likens, and M.R. Church. 1998. Recovery of surface waters in the northeastern U.S. from decreases in atmospheric deposition of sulfur. Water, Air, and Soil Pollution 105:319-329.

Driscoll, C.T., J.R. White, C.G. Schafran, and J.D. Rendall. 1982. Calcium carbonate neutralization of acidified surface waters. Journal of Environmental Engineering ASCE 1128-1145.

Dodds, W.K. 2002. Freshwater ecology concepts and environmental applications. Academic Press, New York, NY. 
Elwood, J.W., J.D. Newbold, A.F. Trimble, and R.W. Stark. 1981. The limiting role of phosphorus in a woodland stream ecosystem: effects of $P$ enrichment on leaf decomposition and primary producers. Ecology. 62(1):146-158.

EPA. 1991. Methods for the determination of metals in environmental samples. EPA 600-91-010. United States Environmental Protection Agency Office of Research and Development, Washington DC, 20460.

Fenoglio, S., P. Agosta, T. Bo, and M. Cucco. 2002. Field experiments on colonization and movements of stream invertebrates in an Apennine river (Visone, NW Italy). Hydrobiologia 474(1-3):125-130.

Fisher, S.G. and G.E. Likens. 1973. Energy flow in Bear Brook, New Hampshire: an integrative approach to stream ecosystem metabolism. Ecological Monographs 43:421-439.

Fiss, F.C. and R.F. Carline. 1993. Survival of brook trout embryos in three episodically acidified streams. Transactions of the American Fisheries Society 22:268-278.

Francoeur, S.N., B.J.F. Biggs, R.A. Smith, and R.L Lowe. 1999. Nutrient limitation of algal biomass accrual in streams: Seasonal patterns and a comparison of methods. Journal of the North American Benthological Society 18(2):242-260.

Freund, J.G. 2004. Local and Regional Impairment of Fish Assemblages in a Mined Appalachian Watershed. Doctorate dissertation. West Virginia University, Morgantown, WV.

Grimm, N.B., and S.G. Fisher. 1986. Nitrogen limitation in a Sonoran desert stream. Journal of the North American Benthological Society 1:2-15.

Gorman, O.T. 1986. Assemblage organization of stream fishes: the effect of rivers on adventitious streams. American Naturalist 128:611-616.

Grubaugh, J.W., J.B. Wallace, and E.S. Houston. 1996. Production of benthic macroinvertebrate communities along a southern Appalachian river continuum. Freshwater Biology 37:581-596.

Hall, R.J. 1990. Relative importance of seasonal, short-term pH disturbances during discharge variation on a stream ecosystem. Canadian Journal of Fisheries and Aquatic Science 47:2261-2274.

Herlihy, A.T., P.R. Kaufmann, M.R. Church, P.J. Wigington, Jr., J.R. Webb, and M.J. Sale. 1993. The effects of acidic deposition on streams in the Appalachian mountain and piedmont region of the Mid-Atlantic United States. Water Resources Research 29(8):2687-2703. 
Hermann, J. and K.G. Andersson. 1986. Aluminum Impact on Respiration of Lotic Mayflies at Low pH. Water, Air, and Soil Pollution 30: 703-709.

Hill, B.H. 1998. Periphyton. Pages 199-132 in J.M. Lazorchak, D.J. Klemm, and D.V. Peck (editors). Environmental Monitoring and Assessment Program - Surface Waters: Field Operations and Methods for Measuring the Ecological Condition of Wadeable Streams. EPA/620/R-94/004F. U.S. Environmental Protection Agency, Washington DC.

Hill, W.R., P.J. Mulholland, and E.R. Marzolf. 2001. Stream ecosystem responses to forest leaf emergence in spring. Ecology 82(8):2306-2319.

Horwitz, R.J. 1978. Temporal variability patterns and the distributional patterns of stream fishes. Ecological Monographs 48(3)307-321.

Howarth, R.W., G. Billen, D.P. Swaney, A. Townsend, N. Jaworski, K. Lajtha, J.A. Downing, R. Elmgren, N. Caraco, T. Jordan, F. Berendse, J. Freney, V. Kudeyarov, P. Murdoch, and Zhu Zhao-liang. 1996. Regional nitrogen budgets and riverine nitrogen and phosphorus fluxes for the drainages to the North Atlantic Ocean: Natural and human influences. Biogeochemistry 35:75-139.

Hynes, H.B.N. 1970. The ecology of running waters. University of Toronto Press, Toronto, ON.

Ingersoll, C.G., D.R. Mount, D.D. Gulley, T.W. LaPoint, and H.L. Bergman. 1990. Effects of $\mathrm{pH}$, aluminum, and calcium on survival and growth of eggs and fry of brook trout (Salvelinus fontinalis). Canadian Journal of Fisheries and Aquatic Sciences 47:1580-1592.

Jordahl, D.M. and A. Benson. 1987. Effect of low pH on survival of brook trout embryos and yolk-sac larvae in West Virginia streams. Transactions of the American Fisheries Society 116:807-816.

Jungar, M.and D. Planas. 1993. Alteration of trophic interactions between periphyton and invertebrates in an acidified stream: a stable carbon isotope study. Hydrobiologia 262: 97-107.

Kimmel, W.G., D.J. Murphey, W.E. Sharpe, and D.R. DeWalle. 1985. Macroinvertebrate community structure and detritus processing rates in two Southwestern Pennsylvania streams acidified by atmospheric deposition. Hydrobiologia 124:97-102.

Kobuszewski, D.M., and S.A. Perry. 1993. Aquatic insect community structure in an acidic and circumneutral stream in the Appalachian Mountains of West Virginia. Journal of Freshwater Ecology 8(1):37-45. 
Krueger, C.C, and T.F. Waters. 1983. Annual production of macroinvertebrates in three streams of different water quality. Ecology 66(4):840-850.

Kwain, W., and G.A. Rose. 1985. Growth of brook trout Salvelinus fontinalis subject to sudden reductions of $\mathrm{pH}$ during their early life history. Transactions of the American Fisheries Society 114:564-570.

Lamberti, G.A. and M. Berg. 1995. Invertebrates and other benthic features as indicators of environmental change in Juday Creek, Indiana. Natural Areas Journal 15:249-258.

Lamothe, P.J. 2002. Spatial population dynamics of brook trout (Salvelinus fontinalis) in a central Appalachian watershed. Master's Thesis. West Virginia University. Morgantown, WV.

Lawrence, G.B., M.B. David, G.M Lovett, P.S. Murdoch, D.A. Burns, J.L. Stoddard, B.P. Baldigo, J.H. Porter, and A.W. Thompson. 1999. Soil calcium states and the response of stream chemistry to changing acidic deposition rates. Ecological Applications 9(3):1059-1072.

Ledger, M.E. and A.G. Hildrew. 1998. Temporal and spatial variation in the epilithic biofilm of an acid stream. Freshwater Biology 40(4):655-670.

Levre, S.R. and W.E. Sharpe. 2002. Acid stream water remediation using limestone sand on Bear Run in Southwestern Pennsylvania. Restoration Ecology 10(2):223-236.

Likens, G.E. and F.H. Bormann. 1995. Biogeochemistry of a forested ecosystem. $2^{\text {nd }}$ edition. Springer-Verlag. New York, NY.

Likens, G.E., C.T. Driscoll, and D.C. Buso. 1996. Long term effects of acid rain: response and recovery of a forest ecosystem. Science 272:244-246.

Lyons, J. 1992. The length of stream to sample with a towed electrofishing unit when fish species richness is estimated. North American Journal of Fisheries Management 12:198-203.

Marschall, E.A., and L.B. Crowder. 1996. Assessing population responses to multiple anthropogenic effects: a case study with brook trout. Ecological Applications 6(1):152-167.

Matthews, G.B., R.A. Matthews, and B. Hachmoller. 1991. Mathematical analysis of temporal and spatial trends in the benthic macroinvertebrate communities of a small stream. Canadian Journal of Fisheries and Aquatic Science 48:2184-2190. 
Maurice, C.G., R.L. Lowe, T.M. Burton, and R.M. Standford. 1987. Biomass and compositional changes in the periphytic community of an artificial stream in response to lowered pH. Water, Air, and Soil Pollution 33:165-177.

McCormick, F. H., R. M. Hughes, P. R. Kaufmann, D. V. Peck, J. L. Stoddard, and A. T. Herlihy. 2001. Development of an index of biotic integrity for the Mid-Atlantic Highland Region. Transactions of the American Fisheries Society 130: 857-877.

McIntire, C.D. and H.K. Phinney. 1965. Laboratory studies of periphyton production and community metabolism in lotic environments. Ecological Monographs 35:237258.

Meegan, S.K. and S.A. Perry. 1996. Periphyton communities in headwater streams of different water chemistry in the central Appalachian mountains. Journal of Freshwater Ecology 11(3):247-256.

Menendez, R. 1976. Chronic effects of reduced pH on brook trout (Salvelinus fontinalis). The Fisheries Research Board of Canada 33:118-123.

Menendez, R., J.L. Clayton, and P.E. Zurbuch. 1996. Chemical and fishery responses to mitigative liming of an acidic stream, Dogway Fork, West Virginia. Restoration Ecology 4(3): 220-233.

Merritt, R.W. and K.W. Cummins. 1996. An introduction to the aquatic insects of North America. $3^{\text {rd }}$ edition, Kendall and Hunt. Dubuque, IA.

Miller, C. 1985. Correlates of habitat favorability for benthic macroinvertebrates at five stream sites in an Appalachian Mountain drainage basin, U.S.A. Freshwater Biology 15:709-733.

Minshall, G.W., R.C. Peterson, K.W. Cummins, T.L. Bott, J.R. Sedell, S.E. Cushing and R.L. Vannote. 1983. Interbiome comparison of stream ecosystem dynamics. Ecological Monographs 53(1):1-25.

Olem, H. 1991. Liming acidic surface waters. Lewis Publishers, Inc., Chelsea, MI.

Ormernik, J.M. 1977. Nonpoint source-stream nutrient level relationships: a nationwide survey. EPA-600/3-77-105, Ecological Research Series, United States Environmental Protection Agency, Washington, District of Columbia, USA.

Osborne, L.L, and M.J. Wiley. 1992. Influence of tributary spatial position on the structure of warm water fish communities. Canadian Journal of Fisheries and Aquatic Sciences 49(4): 671-681. 
Peterson, B.J., L. Deegan, J. Helfrich, J.E. Hobbie, M. Hullar, B. Moller, T.E. Ford, A. Hershey, A. Hiltner, G. Kipphut, M.A. Lock, D.M. Fiebig, V. McKinley, M.C. Miller, J.R. Vestal, R. Ventullo, and G. Volk. 1993. Biological responses of a tundra river to fertilization. Ecology 74:653-672.

Peterson, R.H., K. Coombs, and J. Power. 1989. Responses of several fish species to pH gradients. Canadian Journal of Zoology 67:1566-1572.

Phipps, D.A. 1976. Metals and metabolism. Clarendon Press, Oxford, England.

Porcella, D.B., C.L. Scholfied, J.V. DePinto, C.T. Driscoll, P.A. Buckaveckas, S.P. Gloss, and T.C. Young. 1990. Mitigation of acidic conditions in lakes and streams. Pages 159-186 in S.A. Norton, S.E. Linberg, and A.L. Page (editors). Advances in Environmental Sciences, vol 4. Soils, Aquatic Processes, and Lake Acidification Series. Springer-Verlag, New York, NY.

Pringle, C.M. 1987. Effects of water and substratum nutrient supplies on lotic periphyton growth: an integrated bioassay. Canadian Journal of Fisheries and Aquatic Sciences 44:619-629.

Reece, P.F. and J.S. Richardson. 1998. Seasonal changes of benthic macroinvertebrate communities in southwestern British Columbia. Prepared for Environment Canada Environmental Conservation Branch, Aquatic and Atmospheric Science Division. FRAP Report Number: DOE-FRAP1998-33.

Rosemond, A.D., P.J. Mulholland, and J.W. Elwood. 1993. Top-down and bottom-up control of stream periphyton: effects of nutrients and herbivores. Ecology 74:1264-1280.

Rosemond, A.D., S.R. Reice, J.W. Elwood, and P.J. Mulholland. 1992. The effects of stream acidity on benthic invertebrate communities in the southeastern United States. Freshwater Biology 27:193-209.

Schindler, D.W. 1988. Effects of acid rain of freshwater ecosystems. Science 239:149157.

Sharpe, W.E., V.G. Leibfried, W.G. Kimmel, and D.R. DeWalle. 1987. The relationship of water quality and fish occurrence to soils and geology in an area of high hydrogen and sulfate ion deposition.

Simmons, K.R. and K. Doyle. 1996. Limestone treatment of Whetstone Brook, Massachusetts III. Changes in the invertebrate fauna. Restoration Ecology 4(3):284-292. 
Simmons, K.R. and P.G. Cieslewicz. 1996. Limestone treatment of Whetstone Brook, Massachusetts I. Treatment methodology and water-chemistry changes during treatment. Restoration Ecology 4(3):264-272.

Simpson, K.W., R.W. Bode, and J.R. Colquhoun. 1985. The macroinvertebrate fauna of an acid-stressed headwater stream in the Adirondack mountains, New York. Freshwater Biology 15:671-687.

Stockner, J.G. and K.R.S. Shortreed. 1978. Autotrophic production in Carnation Creek, a coastal rainforest stream on Vancouver Island, British Columbia. Journal of the Fisheries Research Board of Canada 33:1553-1563.

Tank, J.L. and J.R. Webster. 1998. Interaction of substrate and nutrient availability on wood biofilm processes in streams. Ecology. 79(6):2168-2179.

Tebo, L.B. 1955. Effect of siltation, resulting from improper logging, on bottom fauna of a small trout stream in the Appalachians. Progressive Fish-Culturist 17:64-70.

Vannote, R.L., G.W. Minshall, K.W. Cummins, J.R. Sedell, and C.E. Cushing. 1980. The river continuum concept. Canadian Journal of Fisheries and Aquatic Sciences 37:130-137.

Van Sickle, J., J.P. Baker, H.A. Simonin, B.P. Baldigo, W.A. Kretser, and W.E. Sharpe. 1996. Episodic acidification of small streams in northeastern United States: fish mortality in field bioassays. Ecological Applications 6(2)408-421.

Vouri, K. and I. Joensuu. 1996. Impact of forest drainage on the macroinvertebrates of a small boreal headwater stream: Do buffer zones protect lotic biodiversity? Biological conservation 77:87-95.

Weatherley, N.S. 1988. Liming to mitigate acidification in freshwater ecosystems: a review of the biological consequences. Water, Air, and Soil Pollution 39:421-437.

Weatherley, N.S., G.P. Rutt, S.P. Thomas, and S.J. Ormerod. 1991. Liming acid streams: aluminum toxicity to fish in mixing zones. Water, Air, and Soil Pollution 55:345-353.

Wellnitz, T.A., R.B. Rader, and J.V. Ward. 1996. Light and grazing mayfly shape periphyton in a Rocky Mountain stream. Journal of the North American Benthological Society 15(4):496-507.

Welsh, S.A. and S.A. Perry. 1997. Acidification and fish occurrence in the Upper Cheat River drainage, West Virginia. Journal of the American Water Resources Association 33(2):423-429. 
Wiggins, G.B. 1998. Larvae of the North American caddisfly genera. $2^{\text {nd }}$ edition. University of Toronto Press. Toronto, ON.

Wigington, P.J., J.P. Baker, D.R. DeWalle, W.A. Kretser, P.S. Murdoch, H.A. Simonin, J.

Van Sickle, M.K. McDowell, D.V. Peck, and W.R. Barchet. 1996a. Episodic acidification of small streams in the northeastern United States: episodic response project. Ecological Applications 6(2):374-388.

Wigington, P.J. Jr., D.R. DeWalle, P.S. Murdoch, W.A. Krester, H.A. Simonin, J. Van Sickle, and J.P. Baker. 1996b. Episodic acidification of small streams in the northeastern United States: ionic controls of episodes. Ecological Applications 6(2):389-407.

Williams, D.D. and N.E. Williams. 1974. A counter staining technique for use in sorting benthic samples. Limnology and Oceanography 19:152-154.

Wright, R.F., T. Dale, E.T. Gjessing, G.R. Hendrey, A. Henriksen, M. Johannessen, and I.P. Muniz. 1975. Impact of acid precipitation on freshwater ecosystems in Norway. Water, Air, and Soil Pollution 6:483-499.

Zurbuch, P.E., R. Menendez, and J.L. Clayton. 1996. Limestone neutralization of Dogway Fork, West Virginia, by means of a rotary-drum system. Restoration Ecology 4(3):206-219. 
Table 1. Descriptive characteristics of 20 study streams in the Cheat and Gauley watersheds, WV. Sites are sorted by status (A=acidic, $\mathrm{C}=$ circumneutral, and $\mathrm{T}=$ treated with number of years since initial limestone treatment) and basin area. Total habitat score refers to the EPA Rapid Visual Habitat Score (Barbour et al. 1999).

\begin{tabular}{|c|c|c|c|c|c|c|c|c|c|c|c|c|}
\hline Site & Status & Basin & $\begin{array}{c}\text { Basin } \\
\text { area } \\
\left(\mathrm{km}^{2}\right)\end{array}$ & $\begin{array}{c}\text { Mean } \\
\text { discharge } \\
\left(\mathrm{m}^{3} / \mathrm{sec}\right) \\
\end{array}$ & $\begin{array}{c}\text { Mean pH } \\
\text { (SE) }\end{array}$ & $\begin{array}{c}\text { Canopy } \\
\text { cover } \\
(\%) \\
\end{array}$ & $\begin{array}{c}\text { Total } \\
\text { habitat } \\
\text { score }\end{array}$ & $X$ & Y & Nearest mainstem & $\begin{array}{l}\text { Distance to } \\
\text { mainstem } \\
(\mathrm{m})\end{array}$ & $\begin{array}{c}\text { Distance from } \\
\text { treatment } \\
\text { location }(\mathrm{km})\end{array}$ \\
\hline Upper Second Fork & A & Cheat & 3.6 & 0.11 & $4.74(0.24)$ & 93 & 193 & 593157 & 4258676 & Shavers Fork & 4026 & . \\
\hline South Fork Red Creek & $A$ & Cheat & 22.0 & 0.52 & $4.74(0.22)$ & 70 & 147 & 638652 & 4314844 & Red Creek & 153 & $0^{\circ}$ \\
\hline North Fork Cranberry River & A & Gauley & 24.1 & 0.50 & $5.01(0.26)$ & 76 & 183 & 560343 & 4235339 & Cranberry & 1416 & . \\
\hline Red Creek & A & Cheat & 77.0 & 2.00 & $4.93(0.20)$ & 34 & 154 & 638889 & 4315073 & Red Creek & 0 & . \\
\hline Little Odey & C & Cheat & 0.9 & 0.02 & $6.42(0.36)$ & 50 & 191 & 594897 & 4259121 & Shavers Fork & 3241 & \\
\hline Grants Branch & C & Cheat & 3.5 & 0.09 & $6.96(0.22)$ & 95 & 181 & 620484 & 4287511 & Gandy Creek & 78 & . \\
\hline Gandy Run & C & Cheat & 5.5 & 0.14 & $6.66(0.26)$ & 82 & 176 & 637254 & 4315105 & Red Creek & 106 & . \\
\hline Jakeman & C & Gauley & 7.5 & 0.03 & $7.14(0 . .30)$ & 92 & 191 & 538865 & 4237722 & Cranberry & 158 & . \\
\hline Rattlesnake Run & C & Cheat & 9.5 & 0.14 & $7.30(0.14)$ & 89 & 168 & 608034 & 4314637 & Shavers Fork & 832 & . \\
\hline Big Run & C & Cheat & 10.2 & 0.27 & $7.02(0.26)$ & 93 & 172 & 621520 & 4289201 & Gandy Creek & 67 & . \\
\hline Little Black Fork & C & Cheat & 12.3 & 0.17 & $7.22(0.16)$ & 96 & 179 & 610090 & 4315498 & Shavers Fork & 196 & . \\
\hline South Fork Cranberry River & C & Gauley & 36.1 & 0.60 & $6.69(0.17)$ & 78 & 171 & 560981 & 4232141 & Cranberry & 0 & . \\
\hline Big Rocky Run & $\mathrm{T}-2$ & Gauley & 22.2 & 0.41 & $7.11(0.36)$ & 90 & 182 & 548598 & 4225232 & South Fork Cherry & 708 & 4.7 \\
\hline Otter Creek & T-20 & Cheat & 75.1 & 1.97 & $6.65(0.30)$ & 72 & 186 & 620225 & 4322369 & Dry Fork & 196 & 18.3 \\
\hline First Fork & $\mathrm{T}-13$ & Cheat & 22.9 & 0.65 & $6.52(0.28)$ & 47 & 183 & 596015 & 4268572 & Shavers Fork & 45 & 1.5 \\
\hline Red Run & $\mathrm{T}-7$ & Cheat & 12.7 & 0.26 & $6.23(0.14)$ & 89 & 185 & 627562 & 4324870 & Dry Fork & 7728 & 1.2 \\
\hline North Fork Cherry River & $\mathrm{T}-7$ & Gauley & 57.3 & 0.52 & $7.09(0.31)$ & 78 & 173 & 548368 & 4232130 & Cherry & 0 & 10.0 \\
\hline Mcgee Run & $\mathrm{T}-8$ & Cheat & 5.8 & 0.13 & $6.69(0.33)$ & 94 & 189 & 601007 & 4285051 & Shavers Fork & 30 & 1.3 \\
\hline Crouch Run & $\mathrm{T}-13$ & Cheat & 7.2 & 0.13 & $6.58(0.41)$ & 92 & 192 & 600687 & 4281719 & Shavers Fork & 62 & 1.8 \\
\hline Dogway Fork & $\mathrm{T}-16$ & Gauley & 24.8 & 0.44 & $7.46(0.18)$ & 90 & 185 & 554626 & 4234453 & Cranberry & 555 & 10.3 \\
\hline
\end{tabular}


Table 2. Averaged water quality (SE) parameters by stream status for all seasonal sampling periods. Parameter means sharing a common letter do not differ significantly among stream status ( $p>0.05)$.

\begin{tabular}{|c|c|c|c|c|c|c|}
\hline Water chemistry parameter & $\begin{array}{l}\text { Detection } \\
\text { limits }\end{array}$ & Acidic & Circumneutral & Treated & F value & $\begin{array}{c}\text { Degrees of } \\
\text { freedom } \\
\text { (model, error) }\end{array}$ \\
\hline $\mathrm{pH}$ & \pm 0.2 & $4.89(0.14)^{a}$ & $6.91(0.09)^{b}$ & $6.79(0.12)^{b}$ & 66.8 & 2,75 \\
\hline Temperature $\left({ }^{\circ} \mathrm{C}\right)$ & \pm 0.15 & $10.27(0.92)^{a}$ & $12.05(0.53)^{b}$ & $10.05(0.64)^{a}$ & 3.13 & 2,74 \\
\hline Specific Conductance $(\underline{\mathrm{g}} \$ \mathbf{\mathrm { cm }})$ & $\pm 0.5 \%$ & $21.14(1.47)^{a}$ & $42.38(6.73)^{b}$ & $27.59(1.90)^{a b}$ & 4.38 & 2,75 \\
\hline Alkalinity (mg/L CaCO 3 ) & \pm 0.2 & $1.55(0.35)^{a}$ & $9.81(1.43)^{b}$ & $6.59(0.96)^{b}$ & 8.79 & 2,73 \\
\hline Calcium (mg/L) & 0.03 & $1.32(0.10)^{a}$ & $4.09(0.52)^{b}$ & $3.21(0.32)^{b}$ & 7.52 & 2,75 \\
\hline Calcium:Hydrogen & . & $9.89(3.44)^{a}$ & $3300.21(789.2)^{b}$ & $3364.03(1062.1)^{b}$ & 69.21 & 2,75 \\
\hline Potassium (mg/L) & 0.01 & $0.30(0.08)^{a}$ & $0.46(0.05)^{b}$ & $0.21(0.02)^{a}$ & 9.54 & 2,75 \\
\hline Magnesium (mg/L) & 0.02 & $0.50(0.08)^{a}$ & $0.80(0.05)^{b}$ & $0.44(0.03)^{a}$ & 18.73 & 2,75 \\
\hline Sodium (mg/L) & 0.02 & $0.25(0.08)^{a}$ & $0.41(0.04)^{b}$ & $0.21(0.04)^{a}$ & 5.64 & 2,75 \\
\hline Total Phosphorus (mg/L) & 0.03 & $0.05(0.01)^{a}$ & $0.09(0.03)^{a}$ & $0.05(0.006)^{a}$ & 0.67 & 2,75 \\
\hline Dissolved Phosphorus (mg/L) & 0.03 & $0.03(0.002)^{a}$ & $0.04(0.002)^{a}$ & $0.04(0.003)^{a}$ & 1.87 & 2,75 \\
\hline Phosphate (品/L) & 1.0 & $2.22(0.36)^{a}$ & $2.72(0.32)^{a}$ & $2.33(0.26)^{a}$ & 0.69 & 2,75 \\
\hline Total Aluminum (mg/L) & 0.01 & $0.29(0.08)^{a}$ & $0.04(0.008)^{b}$ & $0.14(0.01)^{c}$ & 18.07 & 2,75 \\
\hline Dissolved Aluminum (mg/L) & 0.01 & $0.14(0.02)^{a}$ & $0.02(0.004)^{b}$ & $0.09(0.01)^{a}$ & 21.31 & 2,75 \\
\hline Monomeric Aluminum (mg/L) & 0.01 & $0.08(0.03)^{a}$ & $0.015(0.001)^{b}$ & $0.039(0.009)^{a b}$ & 5.71 & 2,75 \\
\hline Nitrate (mg/L) & 0.02 & $0.19(0.04)^{a}$ & $0.36(0.03)^{b}$ & $0.21(0.03)^{a}$ & 9.56 & 2,75 \\
\hline Sulfate (mg/L) & 0.1 & $4.14(0.33)^{a}$ & $4.22(0.24)^{a}$ & $4.26(0.33)^{a}$ & 0.03 & 2,75 \\
\hline Chloride (mg/L) & 1.0 & $1.02(0.01)^{a}$ & $1.15(0.07)^{a}$ & $1.08(0.03)^{a}$ & 1.34 & 2,75 \\
\hline
\end{tabular}


Table 3. Summary of overall repeated measures ANOVA for each water chemistry variable including $F$ values and statistical differences.

\begin{tabular}{|c|c|c|c|}
\hline Water Chemistry Variable & Status Effect & Season Effect & Status $x$ Season Interaction \\
\hline & $\mathrm{DF}=2,17$ & $\mathrm{DF}=3,49$ & $\mathrm{DF}=6,49$ \\
\hline Alkalinity $\left(\mathrm{CaCO}_{3}\right)^{a}$ & $5.2 *$ & 0.86 & 1.84 \\
\hline $\mathrm{pH}$ & $70.68^{* * *}$ & $23.62 * * *$ & 2.61 * \\
\hline Calcium & 5.19 * & $49 * * *$ & 1.07 \\
\hline Calcium:Hydrogen & $43.30 * * *$ & $15.55^{* * *}$ & 0.93 \\
\hline Potassium & $7.5^{* *}$ & $40.71^{* * *}$ & $6.61^{* * *}$ \\
\hline Magnesium & $12.63^{* * *}$ & 14.26 *** & 2.32 * \\
\hline Sodium & $5.11 *$ & $16.48^{* * *}$ & $3.66^{* *}$ \\
\hline Total Phosphorus & 0.74 & $5.88^{* *}$ & 1.57 \\
\hline Dissolved Phosphorus & 3.5 & 2.55 & 1.55 \\
\hline Phosphate & 3.1 & $1032.4^{* * *}$ & 1.38 \\
\hline Total Aluminum & $29.68^{* * *}$ & $11.92^{* * *}$ & $49^{* * *}$ \\
\hline Dissolved Aluminum & $21.29 * * *$ & $8.1^{* * *}$ & 1.74 \\
\hline Monomeric Aluminum & 4.91 * & 1.51 & 3.08 * \\
\hline Nitrate & $9.65^{* *}$ & $50.15^{* * *}$ & $4.25^{* *}$ \\
\hline Sulfate & 0.07 & $22.74 * * *$ & 2.29 \\
\hline Chloride & 0.95 & 0.45 & 1.36 \\
\hline Temperature $(C)^{b}$ & 4.86 * & 35.96 *** & 2.11 \\
\hline 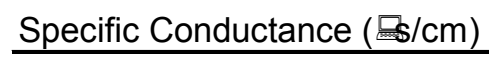 & 3.13 & $7.79 * * *$ & 0.83 \\
\hline $\begin{array}{l}{ }^{*} p<0.05 \\
{ }^{* *} p<0.01 \\
{ }^{* \star *} p<0.001 \\
{ }^{a} \text { D.F. }=2,173,476,47 \\
{ }^{b} \text { D.F. }=2,173,486,48\end{array}$ & & & \\
\hline
\end{tabular}


Table 4. Aquatic benthic macroinvertebrate calculations by site, WV 2003.

\begin{tabular}{|c|c|c|c|c|c|c|c|c|}
\hline Site & Status & $\begin{array}{c}\text { Taxa } \\
\text { richness }\end{array}$ & $\begin{array}{l}\text { Total density } \\
\qquad\left(\mathrm{m}^{2}\right)\end{array}$ & $\begin{array}{l}\text { Total biomass } \\
\left(\mathrm{gDM} / \mathrm{m}^{2}\right)\end{array}$ & $\begin{array}{c}\% \text { Tolerant } \\
\text { taxa biomass }\end{array}$ & $\begin{array}{c}\% \text { Sensitive } \\
\text { taxa biomass }\end{array}$ & $\begin{array}{l}\text { \# Tolerant } \\
\text { taxa }\end{array}$ & $\begin{array}{c}\text { \# Sensitive } \\
\text { taxa }\end{array}$ \\
\hline Upper Second Fork & $A$ & 20 & 1412 & 599 & 93 & 0 & 17 & 0 \\
\hline South Fork Red Creek & $A$ & 14 & 1222 & 398 & 96 & 0 & 13 & 0 \\
\hline North Fork Cranberry & A & 16 & 2076 & 575 & 100 & 0 & 16 & 0 \\
\hline Red Creek & $A$ & 17 & 3450 & 604 & 95 & 0 & 15 & 0 \\
\hline Little Odey & C & 34 & 4288 & 948 & 75 & 11 & 17 & 10 \\
\hline Grants Branch & C & 33 & 2332 & 2039 & 37 & 56 & 15 & 8 \\
\hline Gandy Run & C & 29 & 2408 & 1284 & 36 & 62 & 14 & 11 \\
\hline Jakeman Run & C & 25 & 1208 & 676 & 40 & 55 & 12 & 9 \\
\hline Rattlesnake Run & C & 35 & 2062 & 1970 & 29 & 66 & 15 & 12 \\
\hline Big Run & C & 37 & 2120 & 2134 & 47 & 43 & 16 & 11 \\
\hline Little Black Fork & C & 34 & 3668 & 1801 & 30 & 62 & 15 & 11 \\
\hline South Fork Cranberry & C & 34 & 6322 & 2581 & 36 & 59 & 16 & 13 \\
\hline Mcgee Run & $\mathrm{T}$ & 15 & 372 & 71 & 87 & 2 & 11 & 1 \\
\hline Crouch Run & $\mathrm{T}$ & 11 & 90 & 63 & 93 & 0 & 12 & 0 \\
\hline Red Run & $\mathrm{T}$ & 14 & 836 & 161 & 91 & 2 & 13 & 1 \\
\hline Big Rocky & $\mathrm{T}$ & 22 & 1342 & 312 & 48 & 33 & 13 & 5 \\
\hline First Fork & $\mathrm{T}$ & 16 & 580 & 167 & 77 & 6 & 10 & 2 \\
\hline Dogway Fork & $\mathrm{T}$ & 32 & 1896 & 1670 & 53 & 38 & 15 & 11 \\
\hline North Fork Cherry & $\mathrm{T}$ & 23 & 1680 & 493 & 39 & 37 & 11 & 9 \\
\hline Otter Creek & $\mathrm{T}$ & 19 & 3276 & 848 & 49 & 51 & 13 & 4 \\
\hline
\end{tabular}


Table 5. Mean (SE) benthic macroinvertebrate variables averaged by stream status. Variable means sharing a common letter do not significantly differ $(p<0.05)$.

\begin{tabular}{lccc} 
Benthic macroinvertebrate variable & \multicolumn{1}{c}{ Acidic } & Circumneutral & Treated \\
\hline \hline Taxa richness & $16.75(1.25)^{\mathrm{a}}$ & $33.63(1.35)^{\mathrm{b}}$ & $19.00(2.35)^{\mathrm{a}}$ \\
Density $\left(\mathrm{N} / \mathrm{m}^{2}\right)$ & $2040(504.39)^{\mathrm{ab}}$ & $3051(579.14)^{\mathrm{a}}$ & $1259(364.77)^{\mathrm{b}}$ \\
Biomass $\left(\mathrm{mgDM} / \mathrm{m}^{2}\right)$ & $543.85(49.11)^{\mathrm{a}}$ & $1679.2(229.4)^{\mathrm{b}}$ & $473.05(194.6)^{\mathrm{a}}$ \\
\% Tolerant taxa biomass & $95.77(1.55)^{\mathrm{a}}$ & $41.19(5.14)^{\mathrm{b}}$ & $67.05(7.76)^{\mathrm{c}}$ \\
\% Sensitive taxa biomass & $0(0)^{\mathrm{a}}$ & $52(6.27)^{\mathrm{b}}$ & $21(7.30)^{\mathrm{c}}$ \\
\# Tolerant taxa & $15.25(0.85)^{\mathrm{a}}$ & $15(0.53)^{\mathrm{a}}$ & $12.3(0.56)^{\mathrm{b}}$ \\
\# Sensitive taxa & $0(0)^{\mathrm{a}}$ & $10.6(0.56)^{\mathrm{b}}$ & $4.1(1.42)^{\mathrm{a}}$ \\
\% Filterer biomass & $3.65(1.73)^{\mathrm{a}}$ & $6.42(1.98)^{\mathrm{a}}$ & $5.25(1.4)^{\mathrm{a}}$ \\
\% Gatherer biomass & $24.9(8.81)^{\mathrm{a}}$ & $23.20(2.48)^{\mathrm{a}}$ & $27.84(6.20)^{\mathrm{a}}$ \\
\% Scraper biomass & $23.55(9.05)^{\mathrm{a}}$ & $16.53(2.51)^{\mathrm{a}}$ & $18.94(4.5)^{\mathrm{a}}$ \\
\% Shredder biomass & $7.19(1.11)^{\mathrm{a}}$ & $18.96(6.54)^{\mathrm{a}}$ & $17.99(5.22)^{\mathrm{a}}$ \\
\% Predator biomass & $40.38(9.06)^{\mathrm{a}}$ & $34.70(5.68)^{\mathrm{a}}$ & $28.66(7.63)^{\mathrm{a}}$ \\
\hline
\end{tabular}


Table 6. Summary of ANCOVA statistics for each aquatic benthic macroinvertebrate variable analyzed using a stream status, basin area $\left(\mathrm{km}^{2}\right)$, and relative light model.

\begin{tabular}{|c|c|c|c|c|c|c|}
\hline Response variable & $\mathrm{R}^{2}$ & DF & F-value & P-value & Predictor variable & Correlation \\
\hline \multirow[t]{4}{*}{$\begin{array}{l}\text { Benthic macroinvertebrate } \\
\text { richness }\end{array}$} & & 2 & 17.02 & $0.0001^{*}$ & Status & \\
\hline & & 1 & 1.21 & 0.2896 & Basin area & \\
\hline & & 1 & 0.29 & 0.5962 & Light & \\
\hline & 0.724 & 4 & 9.83 & 0.0004 & Overall model & \\
\hline \multirow[t]{4}{*}{$\begin{array}{c}\text { Benthic macroinvertebrate } \\
\text { density }\left(\mathrm{N} / \mathrm{m}^{2}\right)\end{array}$} & & 2 & 9.27 & $0.0024^{*}$ & Status & \\
\hline & & 1 & 5.96 & $0.0275^{*}$ & Basin area & + \\
\hline & & 1 & 0.8 & 0.3839 & Light & \\
\hline & 0.724 & 4 & 5.34 & 0.007 & Overall model & \\
\hline \multirow[t]{4}{*}{$\begin{array}{l}\text { Benthic macroinvertebrate } \\
\text { biomass }\left(\mathrm{mgDM} / \mathrm{m}^{2}\right)\end{array}$} & & 2 & 17.52 & $0.0001^{*}$ & Status & \\
\hline & & 1 & 7.54 & $0.015^{*}$ & Basin area & + \\
\hline & & 1 & 2.53 & 0.1325 & Light & \\
\hline & 0.72 & 4 & 9.62 & 0.0005 & Overall model & \\
\hline \multirow[t]{4}{*}{$\%$ Tolerant taxa biomass } & & 2 & 28.17 & $<0.0001^{*}$ & Status & \\
\hline & & 1 & 9.03 & $0.0089^{*}$ & Basin area & - \\
\hline & & 1 & 0.99 & 0.3347 & Light & \\
\hline & 0.766 & 4 & 14.84 & $<0.0001$ & Overall model & \\
\hline \multirow[t]{4}{*}{$\%$ Sensitive taxa biomass } & & 2 & 35.67 & $<0.0001^{*}$ & Status & \\
\hline & & 1 & 18.89 & $0.0006^{*}$ & Basin area & + \\
\hline & & 1 & 4.56 & $0.0496^{*}$ & Light & - \\
\hline & 0.645 & 4 & 21.27 & $<0.0001$ & Overall model & \\
\hline
\end{tabular}


Table 6. Continued

\begin{tabular}{|c|c|c|c|c|c|c|}
\hline Response variable & $\mathrm{R}^{2}$ & DF & F-value & P-value & Predictor variable & Correlation \\
\hline \multirow[t]{4}{*}{ \# Tolerant taxa } & & 2 & 6.83 & $0.0078^{*}$ & Status & \\
\hline & & 1 & 0 & 0.988 & Basin area & \\
\hline & & 1 & 0.51 & 0.485 & Light & \\
\hline & 0.498 & 4 & 3.72 & 0.027 & Overall model & \\
\hline \multirow[t]{4}{*}{ \# Sensitive taxa } & & 2 & 22.66 & $<0.0001$ & Status & \\
\hline & & 1 & 2.39 & 0.143 & Basin area & \\
\hline & & 1 & 0.06 & 0.809 & Light & \\
\hline & 0.763 & 4 & 12.09 & 0.0001 & Overall model & \\
\hline \multirow[t]{4}{*}{$\%$ Filterer biomass } & & 2 & 0.71 & 0.5065 & Status & \\
\hline & & 1 & 0.09 & 0.7717 & Basin area & \\
\hline & & 1 & 1.85 & 0.1936 & Light & \\
\hline & 0.153 & 4 & 0.68 & 0.6182 & Overall model & \\
\hline \multirow[t]{4}{*}{$\%$ Gatherer biomass } & & 2 & 0.06 & 0.9413 & Status & \\
\hline & & 1 & 2.43 & 0.1398 & Basin area & \\
\hline & & 1 & 0.36 & 0.5577 & Light & \\
\hline & 0.152 & 4 & 0.67 & 0.6201 & Overall model & \\
\hline \multirow[t]{4}{*}{$\%$ Scraper biomass } & & 2 & 1.33 & 0.2946 & Status & \\
\hline & & 1 & 0.3 & 0.5918 & Basin area & \\
\hline & & 1 & 5.1 & $0.0393^{*}$ & Light & - \\
\hline & 0.3314 & 4 & 1.86 & 0.1702 & Overall model & \\
\hline
\end{tabular}


Table 6. Continued

\begin{tabular}{|c|c|c|c|c|c|c|}
\hline Response variable & $\mathrm{R}^{2}$ & DF & F-value & P-value & Predictor variable & Correlation \\
\hline \multirow[t]{4}{*}{$\%$ Shredder biomass } & & 2 & 0.74 & 0.4948 & Status & \\
\hline & & 1 & 3.58 & $0.0779^{*}$ & Basin area & - \\
\hline & & 1 & 0.22 & 0.6429 & Light & \\
\hline & 0.306 & 4 & 1.65 & 0.213 & Overall model & \\
\hline \multirow[t]{4}{*}{$\%$ Predator biomass } & & 2 & 0.76 & 0.4853 & Status & \\
\hline & & 1 & 0.58 & 0.4597 & Basin area & \\
\hline & & 1 & 4.1 & $0.0612^{*}$ & Light & \\
\hline & 0.346 & 4 & 1.99 & 0.1483 & Overall model & \\
\hline
\end{tabular}


Table 7. Aquatic benthic macroinvertebrate FFG calculations by site.

\begin{tabular}{|c|c|c|c|c|c|c|c|c|c|}
\hline Site & Status & $\begin{array}{c}\text { Basin area } \\
\quad\left(\mathrm{km}^{2}\right)\end{array}$ & $\begin{array}{l}\text { Transformed } \\
\text { relative light }\end{array}$ & $\begin{array}{c}\text { Total } \\
\text { biomass } \\
\left(\mathrm{gDM} / \mathrm{m}^{2}\right)\end{array}$ & $\begin{array}{c}\% \text { Filterer } \\
\text { biomass }\end{array}$ & $\begin{array}{c}\% \text { Gatherer } \\
\text { biomass }\end{array}$ & $\begin{array}{c}\% \text { Scraper } \\
\text { biomass }\end{array}$ & $\begin{array}{c}\% \text { Shredder } \\
\text { biomass }\end{array}$ & $\begin{array}{c}\% \text { Predator } \\
\text { biomass }\end{array}$ \\
\hline North Fork Cranberry & $A$ & 24.07 & 0.52 & 575 & 3 & 9 & 16 & 6 & 66 \\
\hline Red Creek & A & 76.98 & 0.95 & 604 & 8 & 43 & 2 & 6 & 40 \\
\hline South Fork Red Creek & $A$ & 22 & 0.58 & 398 & 0 & 37 & 34 & 6 & 23 \\
\hline Upper Second Fork & $A$ & 3.62 & 0.27 & 599 & 3 & 11 & 42 & 10 & 33 \\
\hline Big Run & C & 10.22 & 0.26 & 2134 & 8 & 28 & 25 & 1 & 36 \\
\hline Gandy Run & C & 5.46 & 0.44 & 1284 & 4 & 31 & 4 & 37 & 24 \\
\hline Grants Branch & C & 3.46 & 0.22 & 2039 & 2 & 14 & 26 & 51 & 6 \\
\hline Jakeman Run & C & 7.49 & 0.29 & 676 & 15 & 23 & 19 & 6 & 38 \\
\hline Little Black Fork & C & 12.34 & 0.20 & 1801 & 1 & 30 & 16 & 30 & 23 \\
\hline Little Odey & C & 0.92 & 0.78 & 948 & 15 & 12 & 13 & 16 & 44 \\
\hline Rattlesnake Run & C & 9.46 & 0.35 & 1970 & 2 & 24 & 17 & 7 & 51 \\
\hline South Fork Cranberry & C & 36.1 & 0.49 & 2581 & 5 & 24 & 13 & 2 & 55 \\
\hline Big Rocky & $\mathrm{T}$ & 22.15 & 0.33 & 312 & 10 & 16 & 38 & 8 & 29 \\
\hline Crouch Run & $\mathrm{T}$ & 7.15 & 0.28 & 63 & 0 & 57 & 12 & 10 & 12 \\
\hline Dogway Fork & $\mathrm{T}$ & 24.75 & 0.33 & 1670 & 6 & 47 & 12 & 26 & 10 \\
\hline First Fork & $\mathrm{T}$ & 22.93 & 0.81 & 167 & 4 & 9 & 11 & 10 & 66 \\
\hline Mcgee Run & $\mathrm{T}$ & 5.8 & 0.25 & 71 & 4 & 8 & 16 & 46 & 25 \\
\hline North Fork Cherry & $\mathrm{T}$ & 57.3 & 0.48 & 493 & 10 & 34 & 39 & 2 & 16 \\
\hline Otter Creek & $\mathrm{T}$ & 75.13 & 0.55 & 848 & 0 & 25 & 4 & 12 & 57 \\
\hline Red Run & $T$ & 12.69 & 0.34 & 161 & 8 & 27 & 19 & 31 & 14 \\
\hline
\end{tabular}


Table 8. Results of fish community sampling July 2004 along with stream status ( $A=$ acidic, $C=$ circumneutral, and $T=$ treated with the number of years since initial limestone treatment), WV.

\begin{tabular}{|c|c|c|c|c|c|}
\hline Stream & Status & Basin & $\begin{array}{l}\text { Basin Area } \\
\left(\mathrm{km}^{2}\right)\end{array}$ & Species & $\begin{array}{c}\# \\
\text { Captured }\end{array}$ \\
\hline Upper Second Fork & $A$ & Cheat & 3.62 & Salvelinus fontinalis & 3 \\
\hline South Fork Red Creek & $A$ & Cheat & 22.00 & $\begin{array}{l}\text { Rhinichthys cataractae } \\
\text { Salvelinus fontinalis }\end{array}$ & $\begin{array}{l}2 \\
5\end{array}$ \\
\hline Red Creek & $A$ & Cheat & 76.98 & $\begin{array}{l}\text { Cottus bairdi } \\
\text { Rhinichthys cataractae } \\
\text { Salvelinus fontinalis }\end{array}$ & $\begin{array}{c}3 \\
20 \\
3\end{array}$ \\
\hline North Fork Cranberry & $A$ & Gauley & 24.07 & NO FISH & 0 \\
\hline Little Odey & $\mathrm{C}$ & Cheat & 0.92 & Salvelinus fontinalis & 100 \\
\hline Grants Branch & C & Cheat & 3.46 & $\begin{array}{l}\text { Cottus bairdi } \\
\text { Salvelinus fontinalis }\end{array}$ & $\begin{array}{l}73 \\
30\end{array}$ \\
\hline Gandy Run & $\mathrm{C}$ & Cheat & 5.46 & $\begin{array}{l}\text { Cottus bairdi } \\
\text { Salvelinus fontinalis }\end{array}$ & $\begin{array}{l}89 \\
56\end{array}$ \\
\hline Rattlesnake Run & $\mathrm{C}$ & Cheat & 9.46 & $\begin{array}{l}\text { Clinostomus funduloides } \\
\text { Cottus bairdi } \\
\text { Rhinichthys atratulus } \\
\text { Rhinichthys cataractae } \\
\text { Salvelinus fontinalis } \\
\text { Semotilus atromaculatus }\end{array}$ & $\begin{array}{c}1 \\
166 \\
35 \\
3 \\
44 \\
24\end{array}$ \\
\hline Big Run & $\mathrm{C}$ & Cheat & 10.22 & $\begin{array}{l}\text { Cottus bairdi } \\
\text { Rhinichthys cataractae } \\
\text { Salvelinus fontinalis } \\
\text { Semotilus atromaculatus }\end{array}$ & $\begin{array}{c}220 \\
11 \\
59 \\
1\end{array}$ \\
\hline Little Black Fork & C & Cheat & 12.34 & $\begin{array}{l}\text { Cottus bairdi } \\
\text { Etheostoma flabellare } \\
\text { Hypentelium nigricans } \\
\text { Micropterus dolomieu } \\
\text { Onchorhynchus mykiss } \\
\text { Rhinichthys atratulus } \\
\text { Rhinichthys cataractae } \\
\text { Salvelinus fontinalis } \\
\text { Salmo trutta } \\
\text { Semotilus atromaculatus }\end{array}$ & $\begin{array}{c}84 \\
1 \\
2 \\
6 \\
20 \\
5 \\
25 \\
9 \\
1 \\
1\end{array}$ \\
\hline
\end{tabular}


Table 8. Continued

\begin{tabular}{|c|c|c|c|c|c|}
\hline Stream & Status & Basin & Basin Area & Species & $\begin{array}{c}\# \\
\text { Captured }\end{array}$ \\
\hline Jakeman Run & C & Gauley & 7.49 & $\begin{array}{l}\text { Campostoma anomalum } \\
\text { Salvelinus fontinalis }\end{array}$ & $\begin{array}{c}1 \\
71\end{array}$ \\
\hline South Fork Cranberry & C & Gauley & 36.10 & $\begin{array}{l}\text { Campostoma anomalum } \\
\text { Catostomus commersoni } \\
\text { Clinostomus funduloides } \\
\text { Etheostoma flabellare } \\
\text { Onchorhynchus mykiss } \\
\text { (golden) } \\
\text { Nocomis micropogon } \\
\text { Onchorhynchus mykiss } \\
\text { Phoxinus oreas } \\
\text { Rhinichthys atratulus } \\
\text { Rhinichthys cataractae } \\
\text { Salvelinus fontinalis } \\
\text { Salmo trutta } \\
\text { Semotilus atromaculatus }\end{array}$ & $\begin{array}{c}1 \\
11 \\
33 \\
153 \\
\\
1 \\
1 \\
2 \\
1 \\
223 \\
62 \\
4 \\
10 \\
17\end{array}$ \\
\hline McGee Run & $\mathrm{T}-8$ & Cheat & 5.80 & $\begin{array}{l}\text { Campostoma anomalum } \\
\text { Cottus bairdi } \\
\text { Rhinichthys atratulus } \\
\text { Rhinichthys cataractae } \\
\text { Salvelinus fontinalis } \\
\text { Semotilus atromaculatus }\end{array}$ & $\begin{array}{c}1 \\
5 \\
27 \\
1 \\
54 \\
31\end{array}$ \\
\hline Crouch Run & $\mathrm{T}-13$ & Cheat & 7.15 & $\begin{array}{l}\text { Clinostomus funduloides } \\
\text { Etheostoma flabellare } \\
\text { Rhinichthys atratulus } \\
\text { Rhinichthys cataractae } \\
\text { Salvelinus fontinalis } \\
\text { Salmo trutta }\end{array}$ & $\begin{array}{c}5 \\
6 \\
10 \\
10 \\
85 \\
2\end{array}$ \\
\hline Red Run & $\mathrm{T}-7$ & Cheat & 12.69 & Salvelinus fontinalis & 111 \\
\hline
\end{tabular}


Table 8. Continued

\begin{tabular}{|c|c|c|c|c|c|}
\hline Stream & Status & Basin & Basin Area & Species & $\begin{array}{c}\# \\
\text { Captured }\end{array}$ \\
\hline \multirow[t]{14}{*}{ First Fork } & $\mathrm{T}-13$ & Cheat & 22.93 & Campostoma anomalum & 1 \\
\hline & & & & Catostomus commersoni & 15 \\
\hline & & & & Nocomis micropogon & 10 \\
\hline & & & & Clinostomus funduloides & 59 \\
\hline & & & & Cottus bairdi & 198 \\
\hline & & & & Etheostoma flabellare & 59 \\
\hline & & & & Pararhinichthys bowersi & 1 \\
\hline & & & & Hypentelium nigricans & 2 \\
\hline & & & & Onchorhynchus mykiss & 2 \\
\hline & & & & Phoxinus oreas & 6 \\
\hline & & & & Rhinichthys atratulus & 67 \\
\hline & & & & Rhinichthys cataractae & 9 \\
\hline & & & & Salvelinus fontinalis & 11 \\
\hline & & & & Semotilus atromaculatus & 6 \\
\hline \multirow{7}{*}{ Otter Creek } & T-20 & Cheat & 75.13 & Ambloplites rupestris & 15 \\
\hline & & & & Campostoma anomalum & 1 \\
\hline & & & & Cottus bairdi & 66 \\
\hline & & & & Micropterus dolomieu & 3 \\
\hline & & & & Rhinichthys atratulus & 1 \\
\hline & & & & Rhinichthys cataractae & 30 \\
\hline & & & & Salvelinus fontinalis & 16 \\
\hline \multirow[t]{6}{*}{ Big Rocky Run } & T-2 & Gauley & 22.15 & Etheostoma flabellare & 54 \\
\hline & & & & Rhinichthys atratulus & 11 \\
\hline & & & & Rhinichthys cataractae & 25 \\
\hline & & & & Salvelinus fontinalis & 33 \\
\hline & & & & Salmo trutta & 1 \\
\hline & & & & Semotilus atromaculatus & 6 \\
\hline \multirow[t]{6}{*}{ Dogway Fork } & T-16 & Gauley & 24.75 & Catostomus commersoni & 3 \\
\hline & & & & Etheostoma flabellare & 94 \\
\hline & & & & Rhinichthys cataractae & 6 \\
\hline & & & & Salvelinus fontinalis & 75 \\
\hline & & & & Salmo trutta & 28 \\
\hline & & & & $\begin{array}{l}\text { Salmo trutta } x \text { salvelinus } \\
\text { fontinalis }\end{array}$ & 1 \\
\hline \multirow{5}{*}{ North Fork Cherry } & $\mathrm{T}-7$ & Gauley & 57.30 & Etheostoma flabellare & 120 \\
\hline & & & & Onchorhynchus mykiss & 2 \\
\hline & & & & Rhinichthys atratulus & 136 \\
\hline & & & & Salvelinus fontinalis & 43 \\
\hline & & & & Salmo trutta & 7 \\
\hline
\end{tabular}


Table 9. A summary of the degree of recovery in water chemistry, biofilm, macroinvertebrates, and fishes in acid impaired limestone treated streams compared to circumneutral reference conditions, WV.

\begin{tabular}{ccc}
\hline & Water chemistry & $\begin{array}{c}\text { Biofilm, Macroinvertebrates, and } \\
\text { Fishes }\end{array}$ \\
\hline \hline Recovered & $\mathrm{pH}$ & Trout density \\
& $\mathrm{Ca}^{2+}$ & Trout yoy density \\
& Alkalinity & \\
Ca:H ratios & Total Al & Macroinvertebrate taxa richness \\
& Dissolved Al & Macroinvertebrate taxa biomass* \\
Not recovered & Number of acid sensitive \\
& Monomeric Al & macroinvertebrate taxa* \\
& Potassium & Fish biomass* \\
& Magnesium & \\
& Sodium & \\
& Nitrate & \\
\hline
\end{tabular}

Level of recovery dependent upon basin area

Fish species richness

\begin{tabular}{ccc}
\hline $\begin{array}{l}\text { Level of recovery dependent upon } \\
\text { distance to treatment location }\end{array}$ & $\begin{array}{c}\text { Macroinvertebrate density } \\
\text { Percent acid tolerant } \\
\text { macroinvertebrate taxa biomass } \\
\text { Percent acid sensitive } \\
\text { macroinvertebrate taxa biomass }\end{array}$ \\
\hline No stream status influence & Total phosphorus & Biofilm biomass \\
& Dissolved phosphorus & \\
& Phosphate & \\
& Chloride & \\
Sulfate & \\
\hline
\end{tabular}

${ }^{*}$ With the exception of the treated Dogway Fork. 


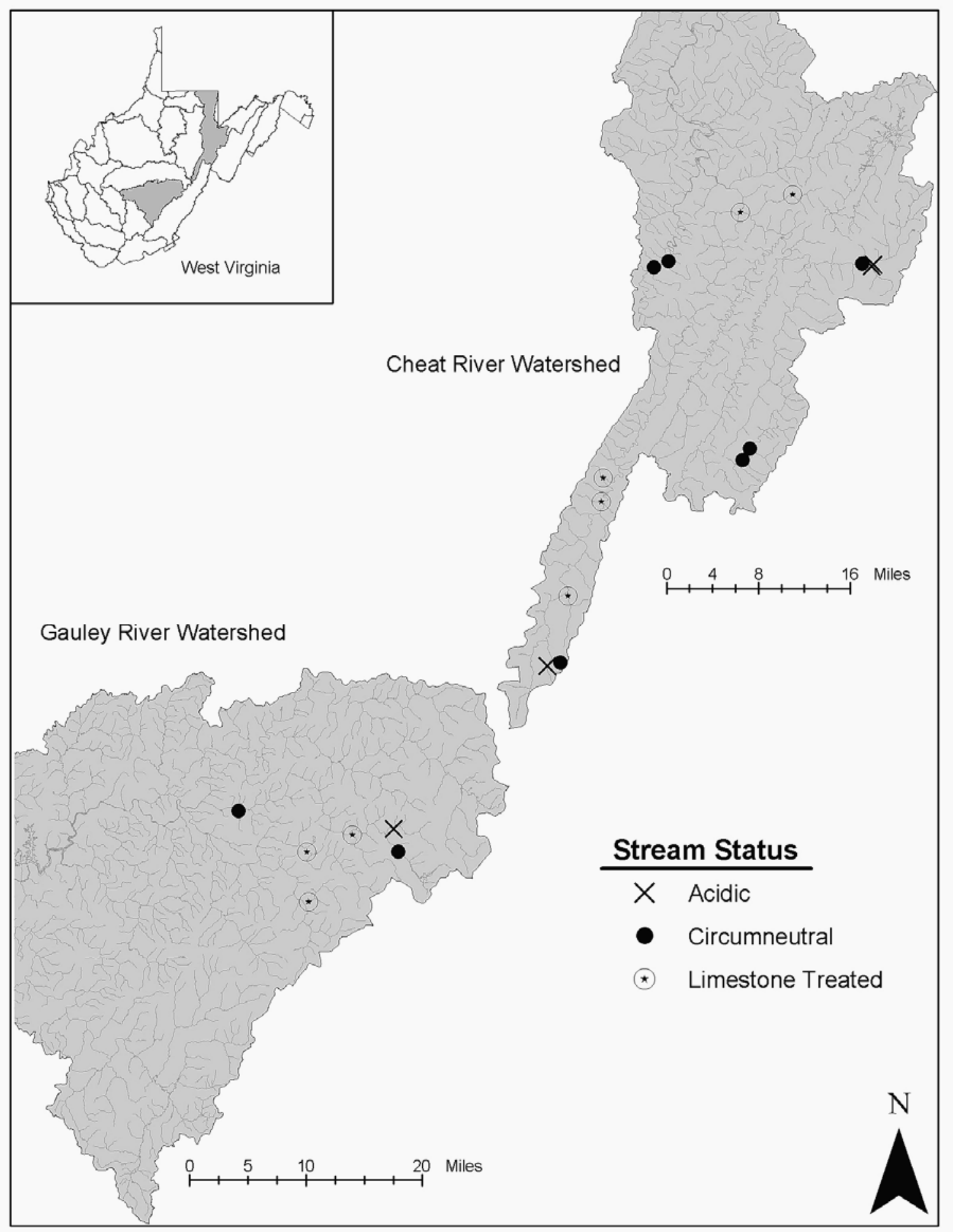

Figure 1. Study locations and corresponding stream status within the Cheat and Gauley River watersheds, WV. 

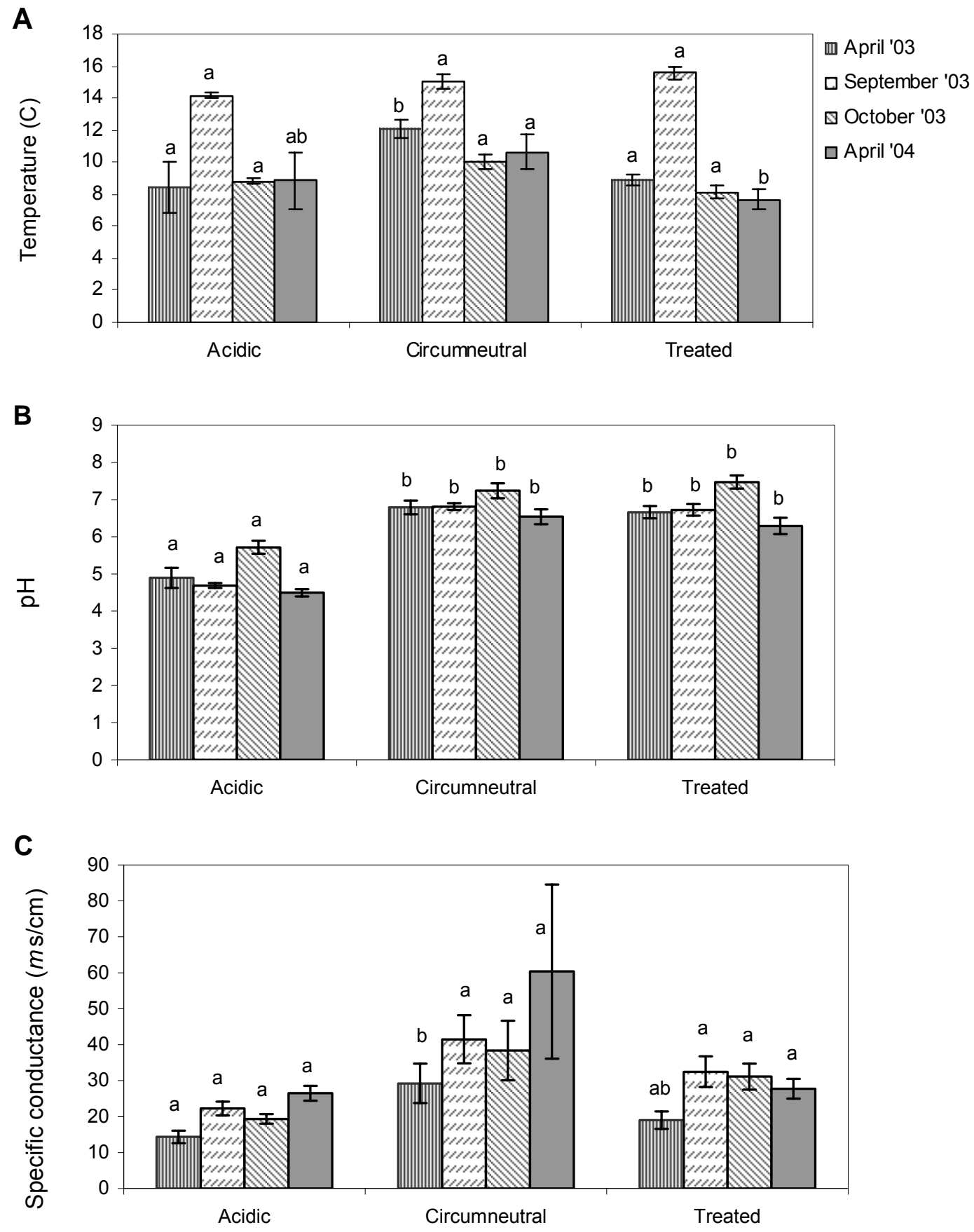

Figure 2. Mean ( $\pm \mathrm{SE}$ ) temperature, $\mathrm{pH}$, and specific conductance by stream status for April, September, and October, 2003 and April 2004 samples. Different letters indicate significant differences among stream status within seasonal sampling periods $(p<0.05)$. 


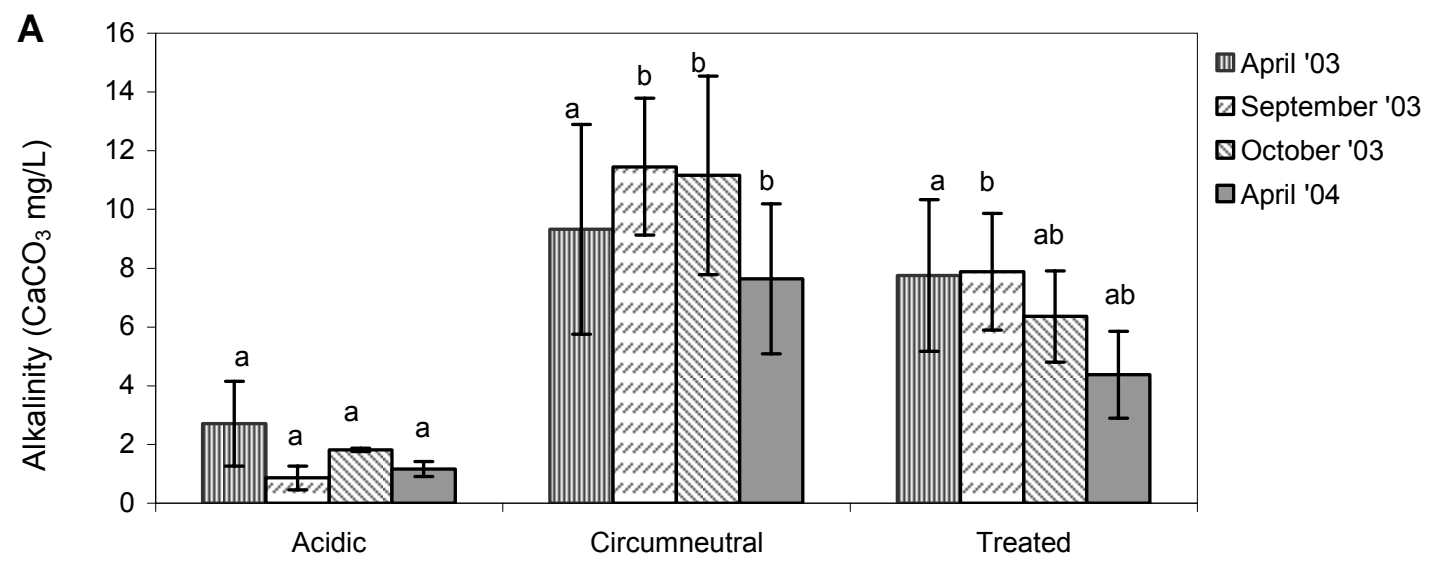

B
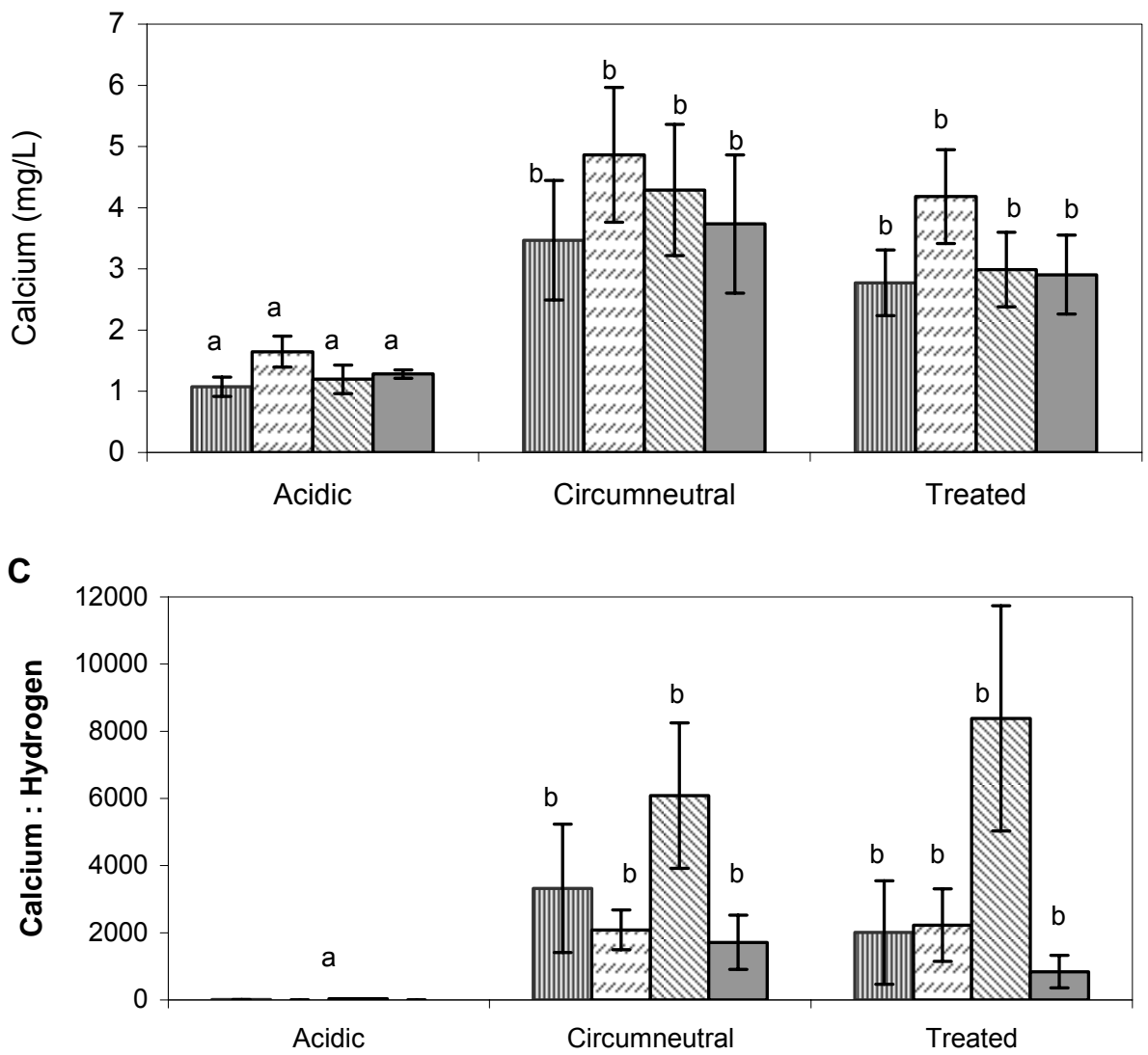

Figure 3. Mean ( \pm SE) alkalinity, calcium, and calcium to hydrogen ratios by stream status for April, September, and October, 2003 and April 2004 samples. Different letters indicate significant differences among stream status within seasonal sampling periods $(p<0.05)$. 



Figure 4. Mean ( $\pm \mathrm{SE}$ ) potassium, magnesium, and sodium by stream status for April, September, and October, 2003 and A pril 2004 samples. Different letters indicate significant differences among stream status within seasonal sampling periods $(p<0.05)$. 

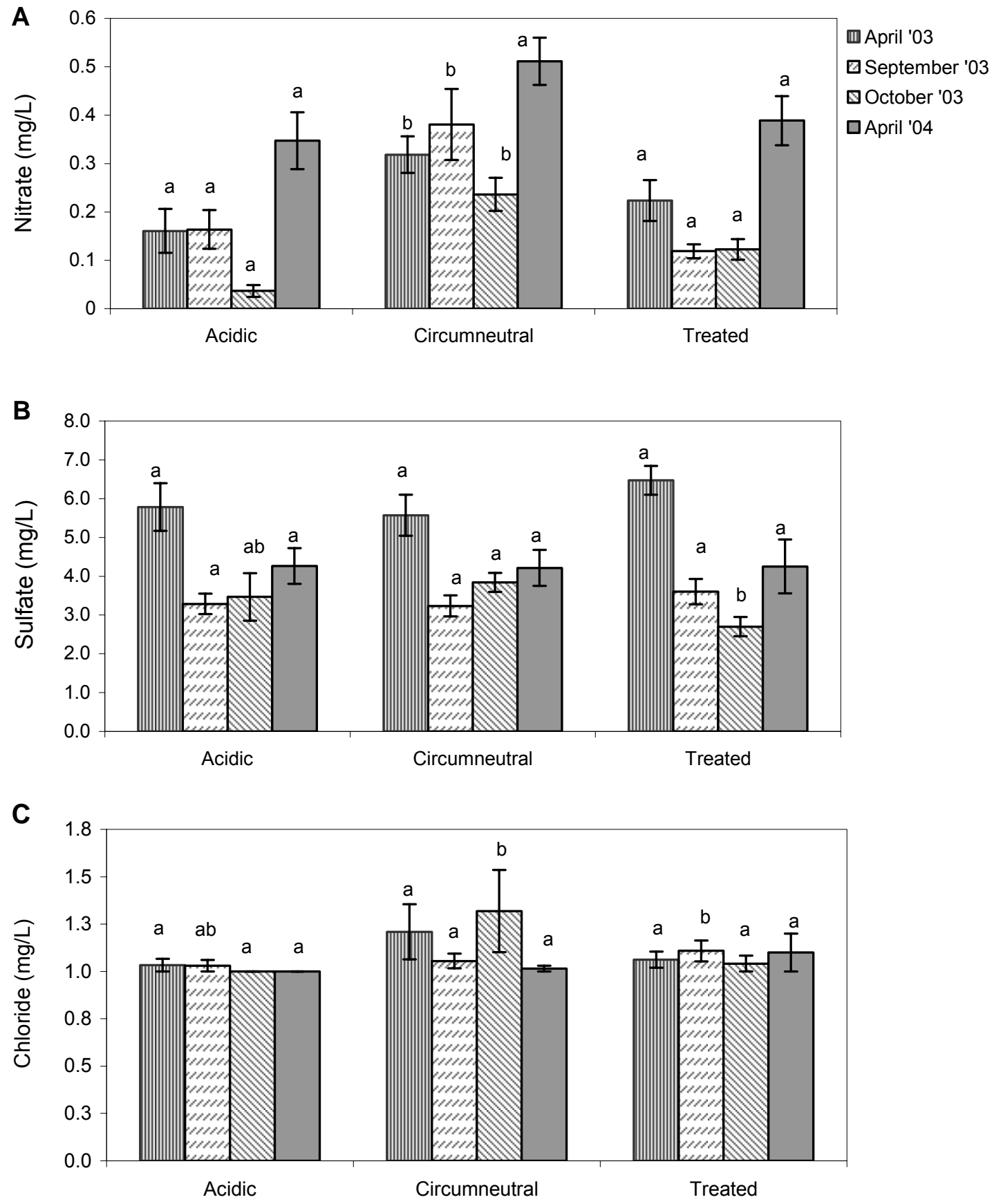

Figure 5. Mean ( $\pm \mathrm{SE})$ nitrate, sulfate, and chloride by stream status for April, September, and October, 2003 and April 2004 samples. Different letters indicate significant differences among stream status within seasonal sampling periods $(p<0.05)$. 
A

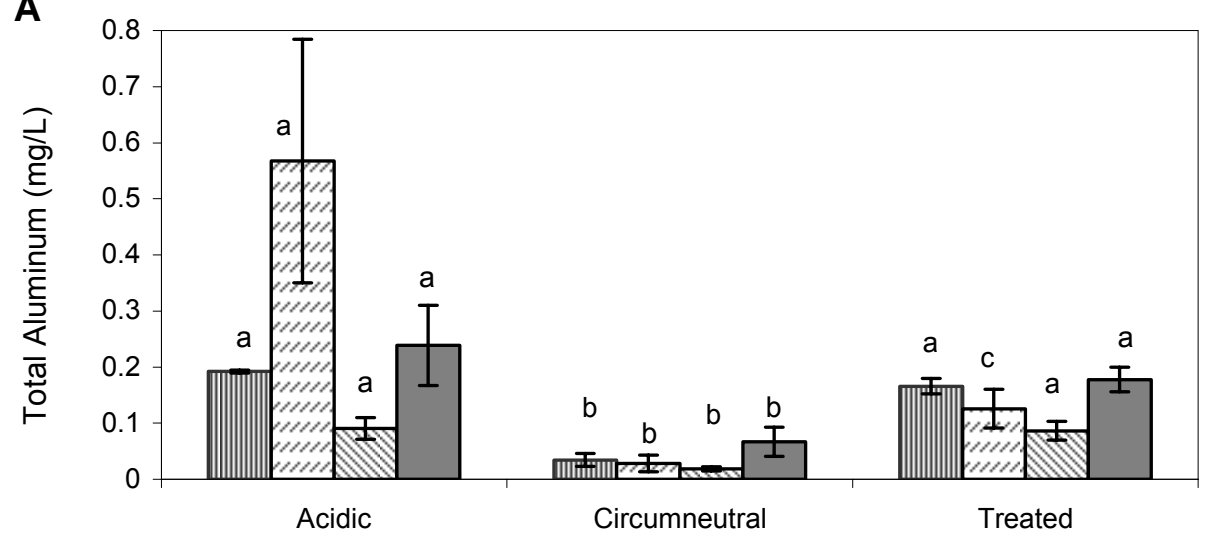

m April '03

口 September '03

Q October '03

口April '04
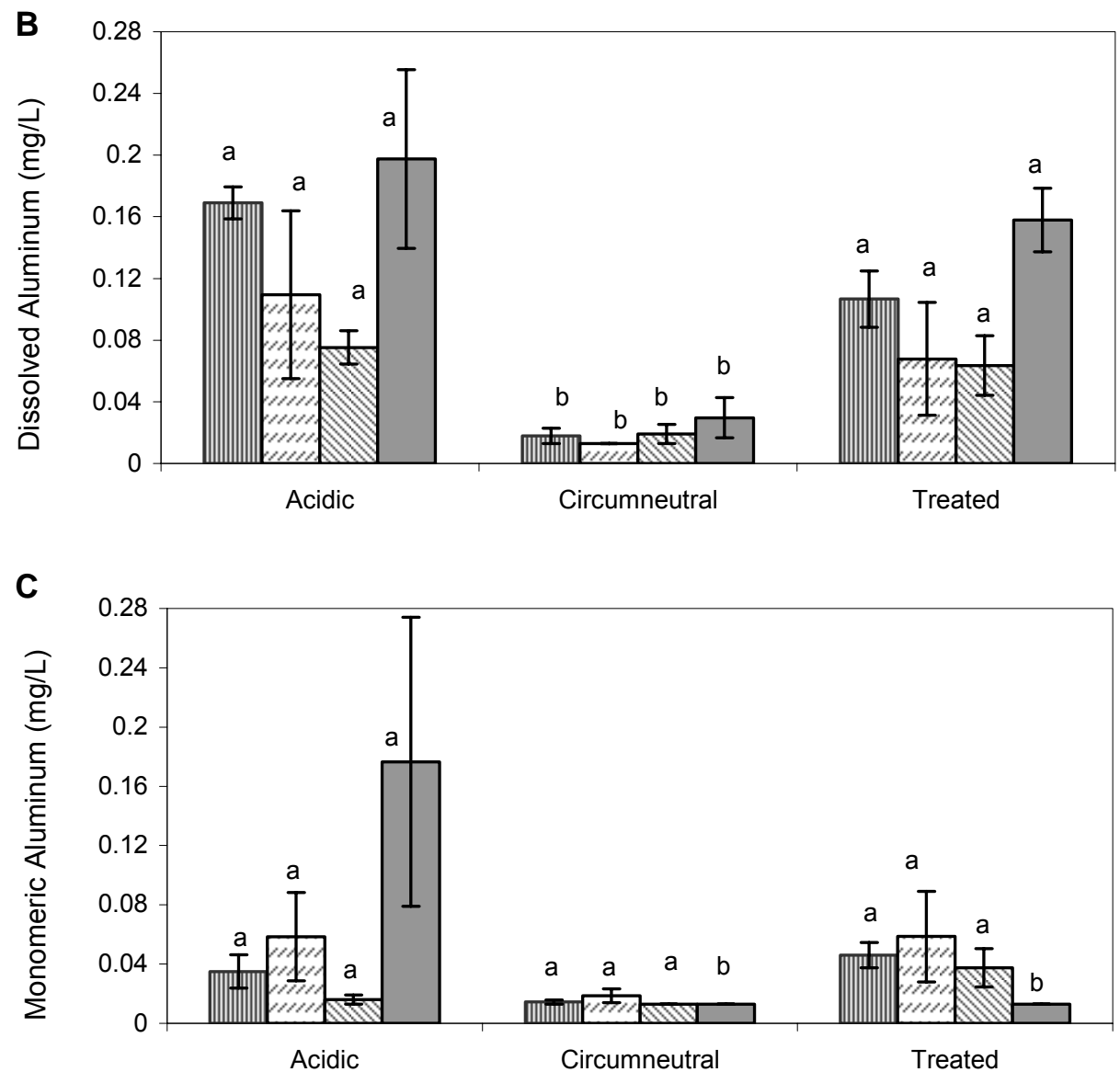

Figure 6. Mean ( $\pm \mathrm{SE}$ ) total, dissolved, and inorganic monomeric aluminum by stream status for April, September, and October, 2003 and April 2004 samples. Different letters indicate significant differences among stream status within seasonal sampling periods $(p<0.05)$. 

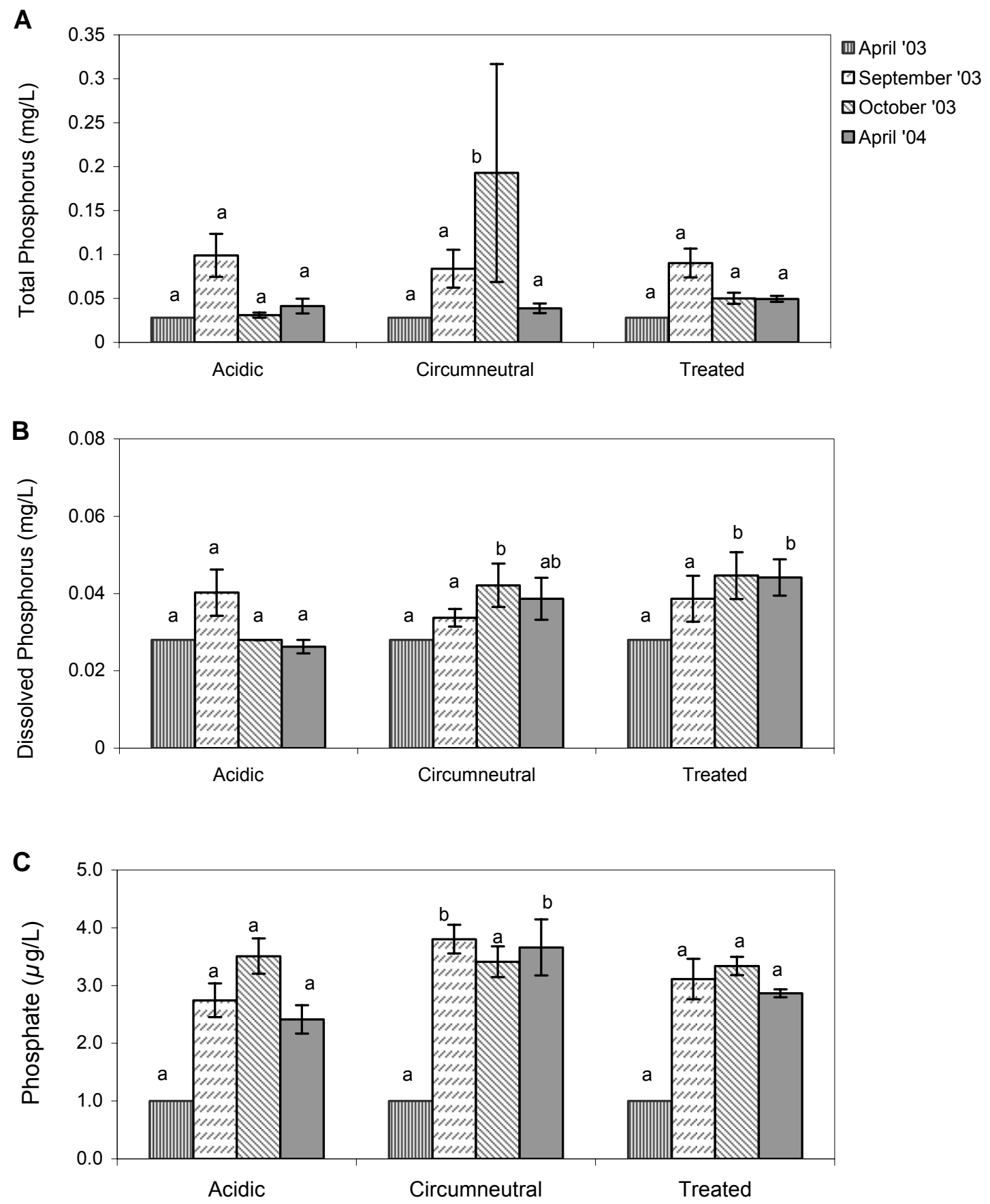

Figure 7. Mean $( \pm S E)$ total phosphorus, dissolved phosphorus, and phosphate by stream status for April, September, and October, 2003 and April 2004 samples. Different letters indicate significant differences among stream status within seasonal sampling periods $(p<0.05)$. 

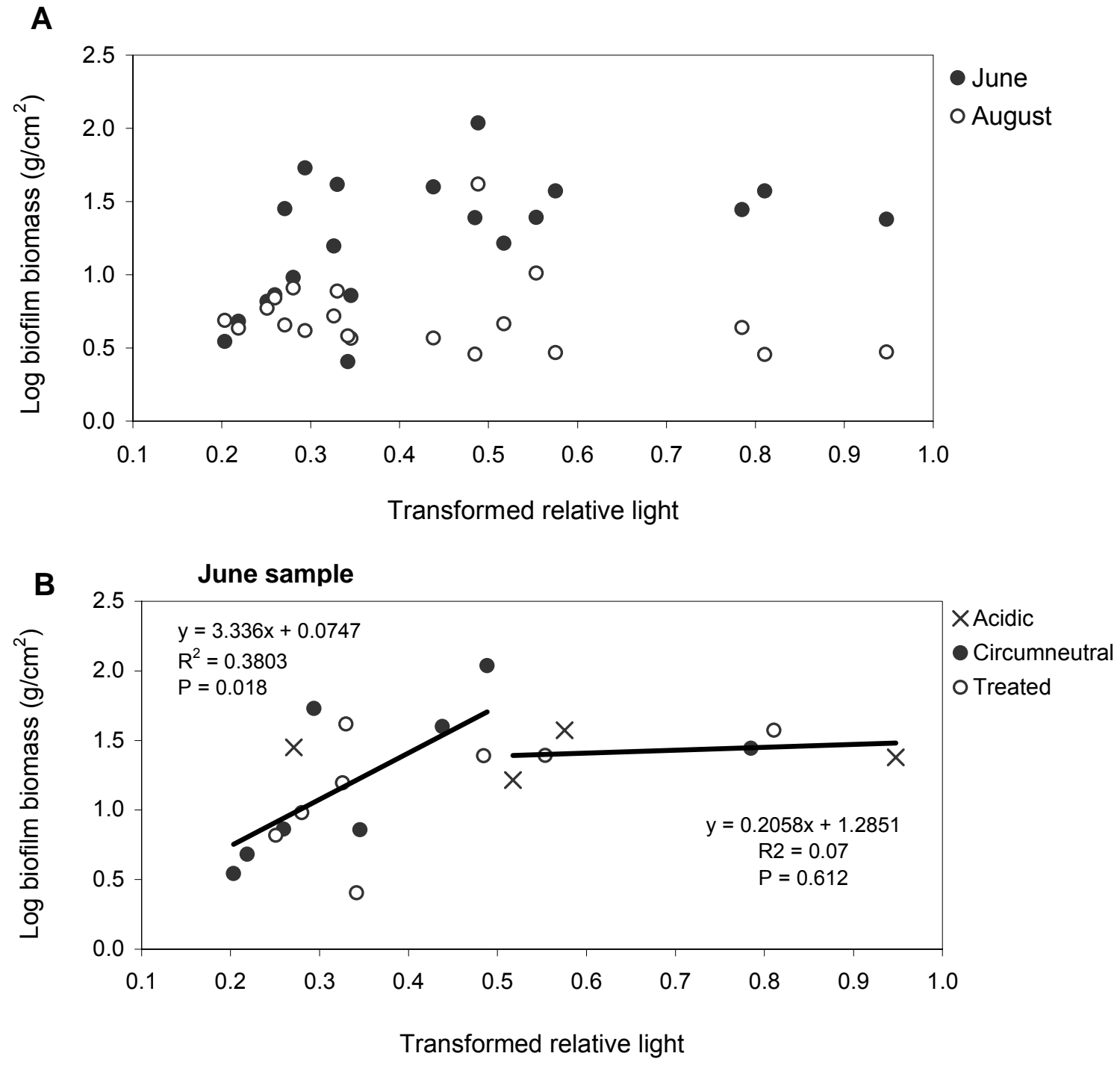

Figure 8. Biofilm biomass as a function of relative light within stream reach. Simple linear regressions were used to fit a line to all samples $<0.5$ and $>0.5$ transformed relative light within the June sampling period. 




Figure 9. Distance from sample location to limestone treatment location as a function of basin area in limestone treated Central Appalachian streams, WV 2003. 

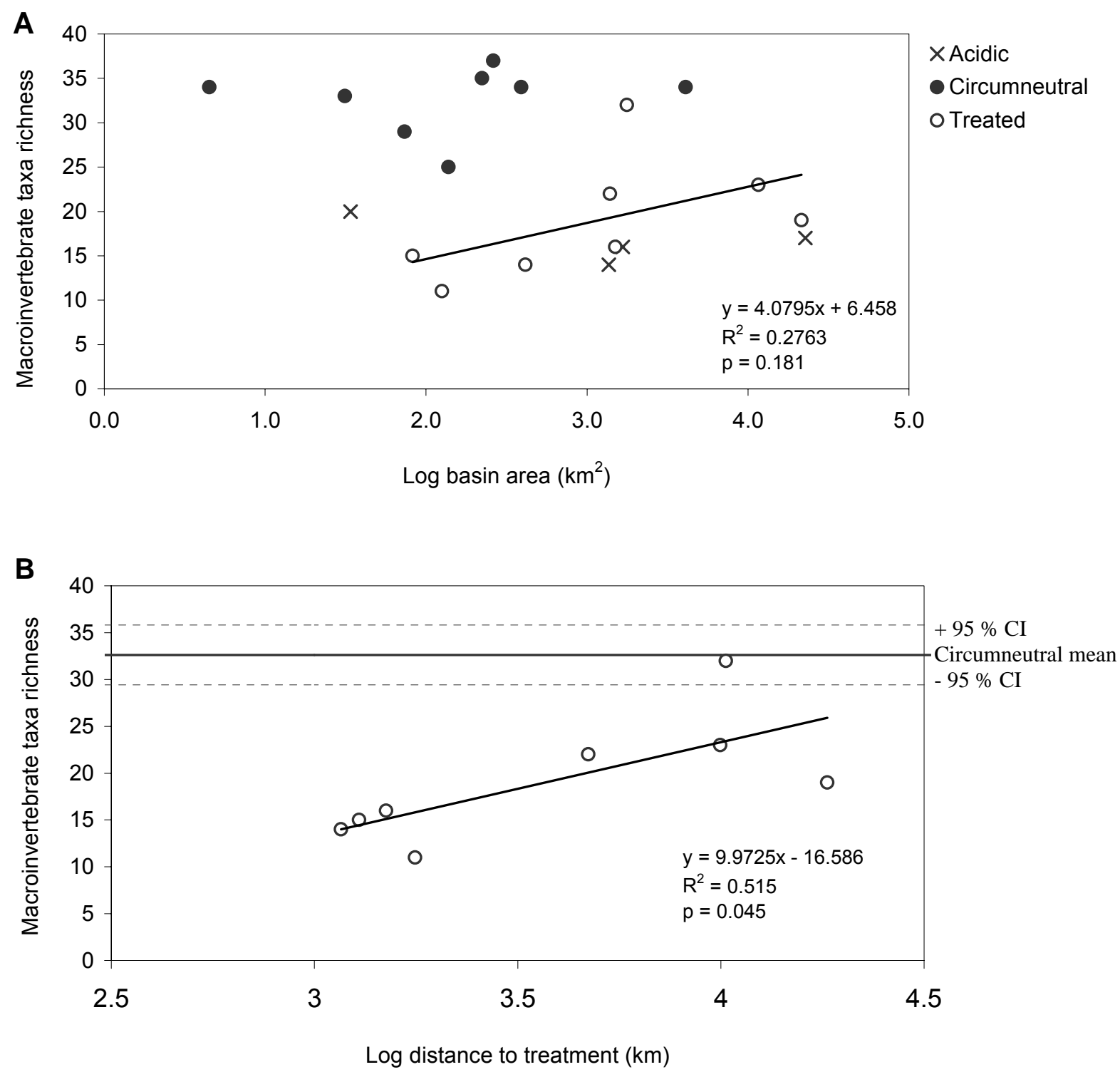

Figure 10. Benthic macroinvertebrate taxa richness as a function of basin area (A). Treated stream macroinvertebrate taxa richness as a function of distance to treatment location and average macroinvertebrate taxa richness $( \pm 95 \% \mathrm{Cl})$ in circumneutral streams (B). Simple linear regressions were used to fit lines for treated streams to basin area and distance to treatment. 

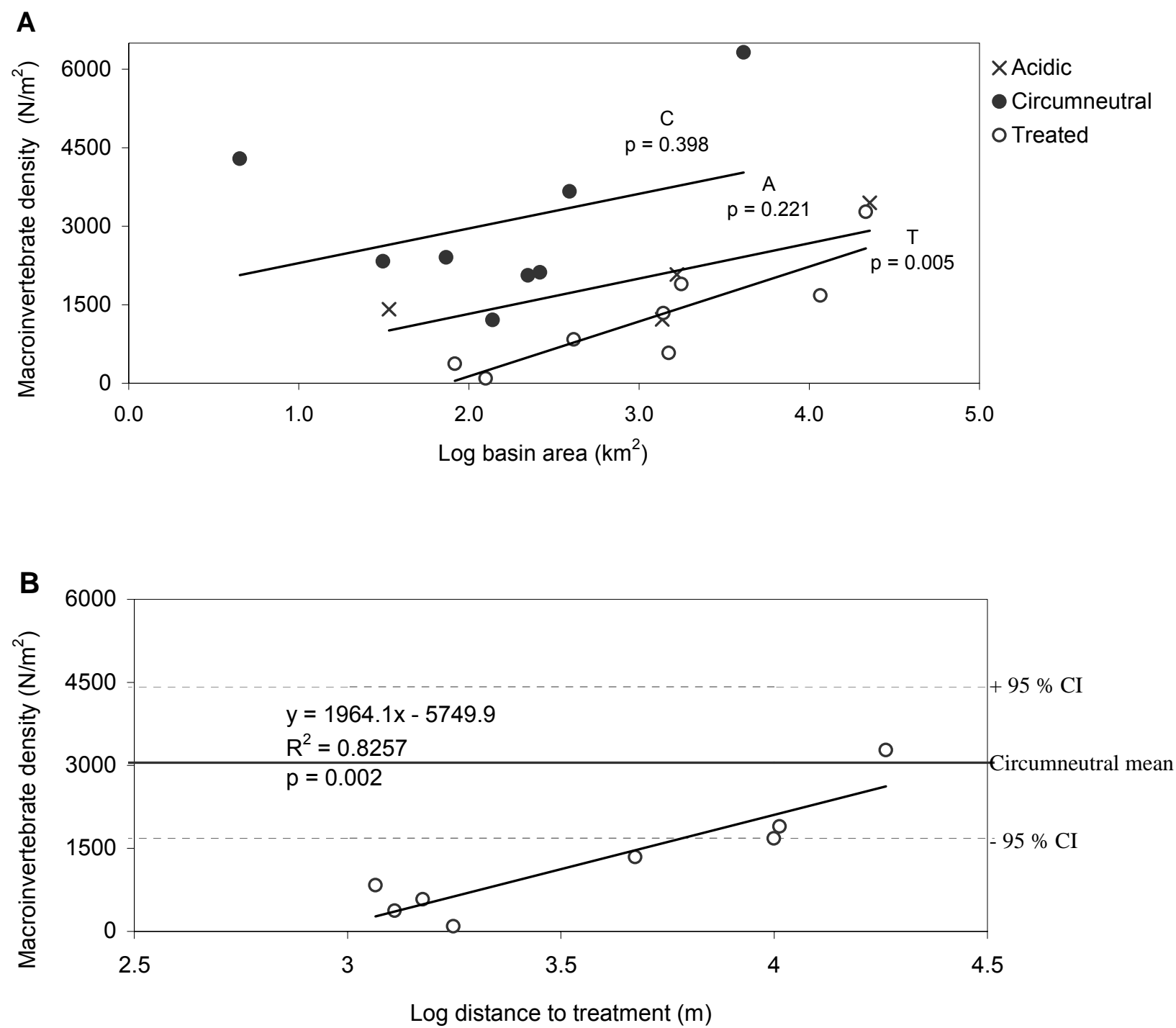

Figure 11. Total benthic macroinvertebrate density by site as a function of basin area (A). Treated total benthic macroinvertebrate density as a function of distance to treatment location and average macroinvertebrate density $( \pm 95 \% \mathrm{Cl})$ in circumneutral streams (B). Simple linear regressions were used to fit lines for all samples to basin area (C: $y=660.94 x+1636.5, R^{2}=0.1209 A: y=674.34 x-24.171, R^{2}=$ 0.6036 and $T: y=1049.2 x-1966.8, R^{2}=0.7554$, and treated streams to distance to treatment. 

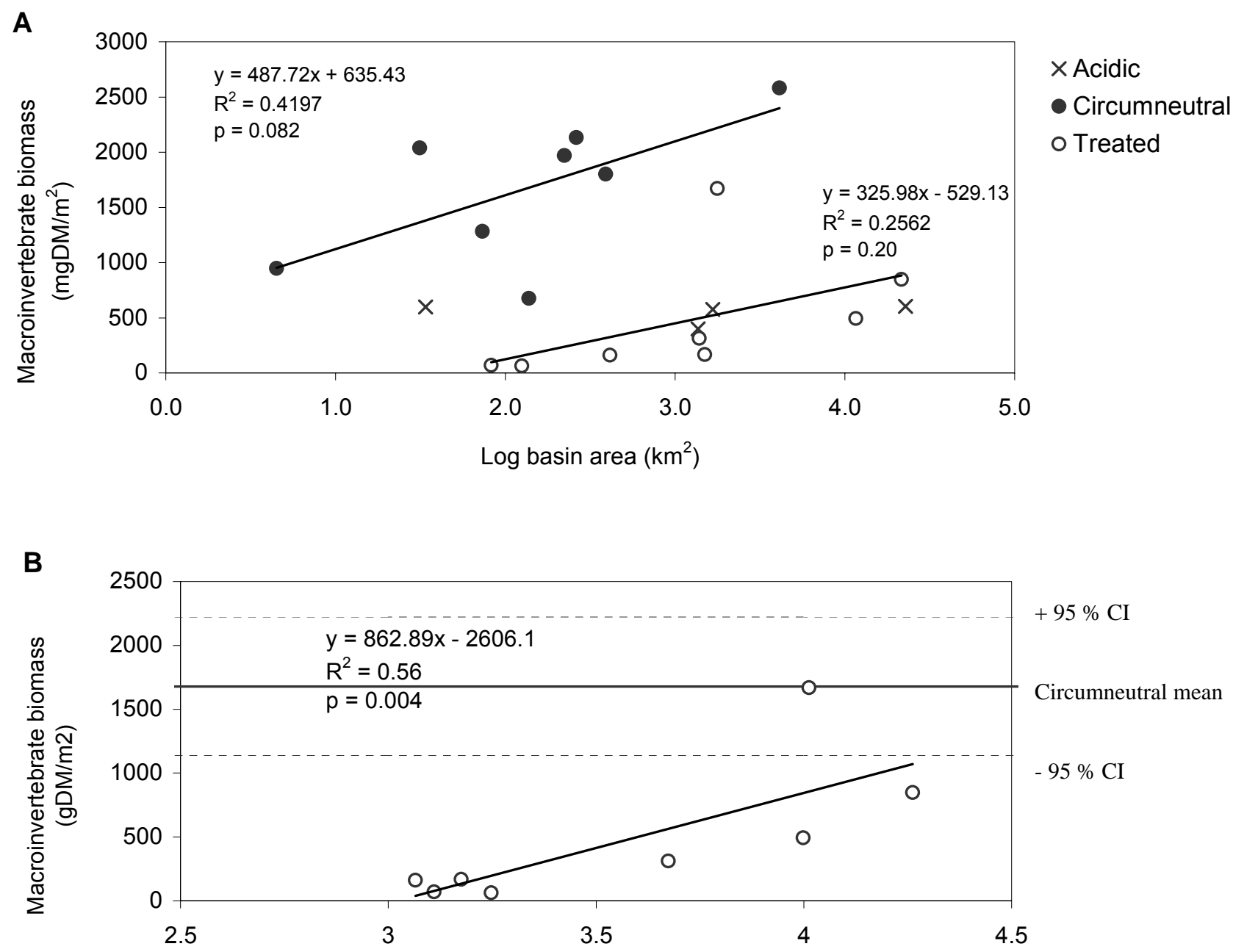

Log distance to treatment (m)

Figure 12. Total benthic macroinvertebrate biomass by site as a function of basin area (A). Treated stream total benthic macroinvertebrate biomass as a function of distance to treatment location and average macroinvertebrate biomass $( \pm 95 \% \mathrm{Cl})$ in circumneutral streams (B). Simple linear regressions were used to fit lines for circumneutral and treated streams to basin area, and treated streams to distance to treatment. 



Figure 13. Percent acid tolerant macroinvertebrate taxa biomass as a function of basin area (A). Treated stream percent acid tolerant macroinvertebrate taxa biomass as a function of distance to treatment location and average percent acid tolerant macroinvertebrate taxa biomass $( \pm 95 \% \mathrm{Cl})$ in circumneutral streams $(B)$. Simple linear regressions were used to fit lines for circumneutral and treated sites to basin area and treated streams to distance to treatment location. 



Figure 14. Percent acid sensitive macroinvertebrate taxa biomass as a function of basin area $(A)$. Treated stream percent acid sensitive macroinvertebrate taxa biomass as a function of distance to treatment location and average percent acid sensitive macroinvertebrate taxa biomass $( \pm 95 \% \mathrm{Cl})$ in circumneutral streams (B). Simple linear regressions were used to fit lines for circumneutral and treated sites to basin area and treated streams to distance to treatment location. 


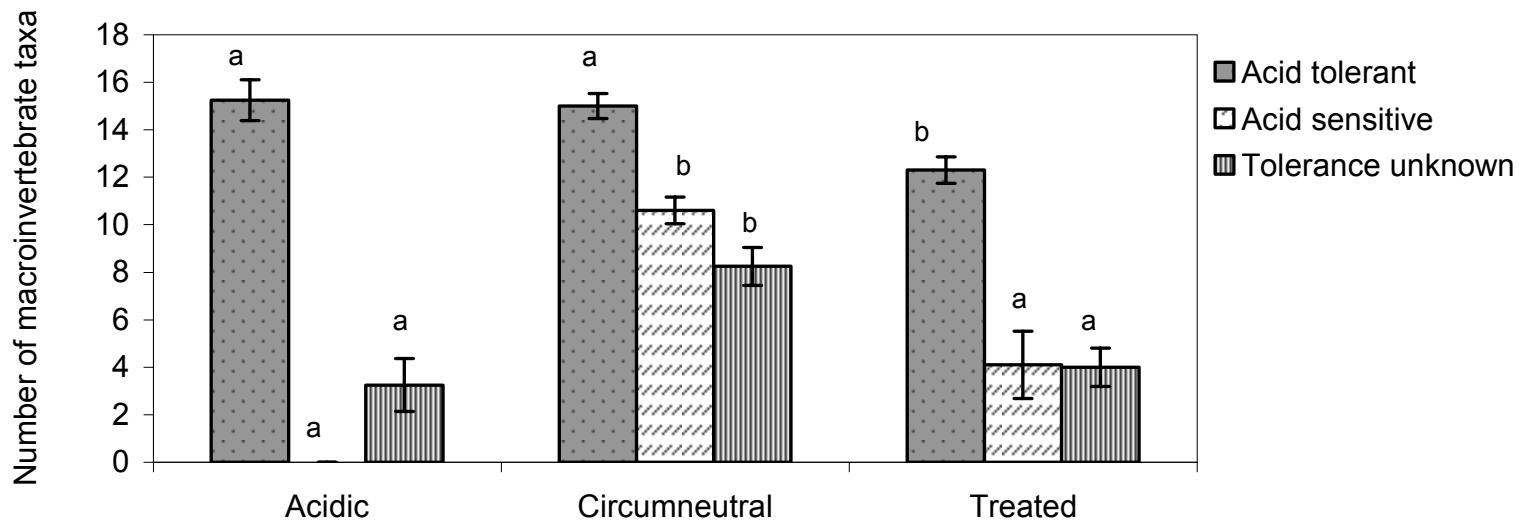

Figure 15. Number of acid tolerant, sensitive, and tolerance unknown taxa averaged by stream status. Different letters indicate significant differences among stream status within taxa classifications $(p<0.05)$. 


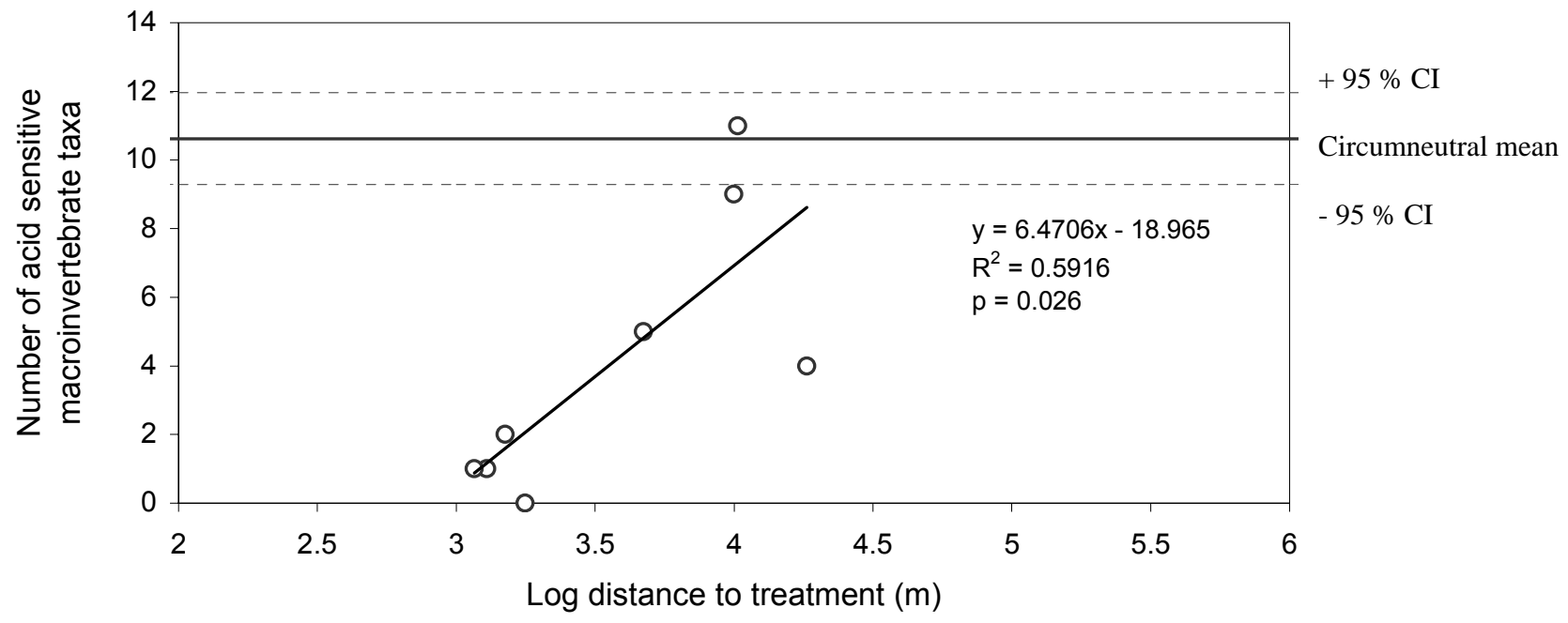

Figure 16. Number of acid sensitive taxa present in limestone treated streams as a function of distance to treatment location, WV 2003. 


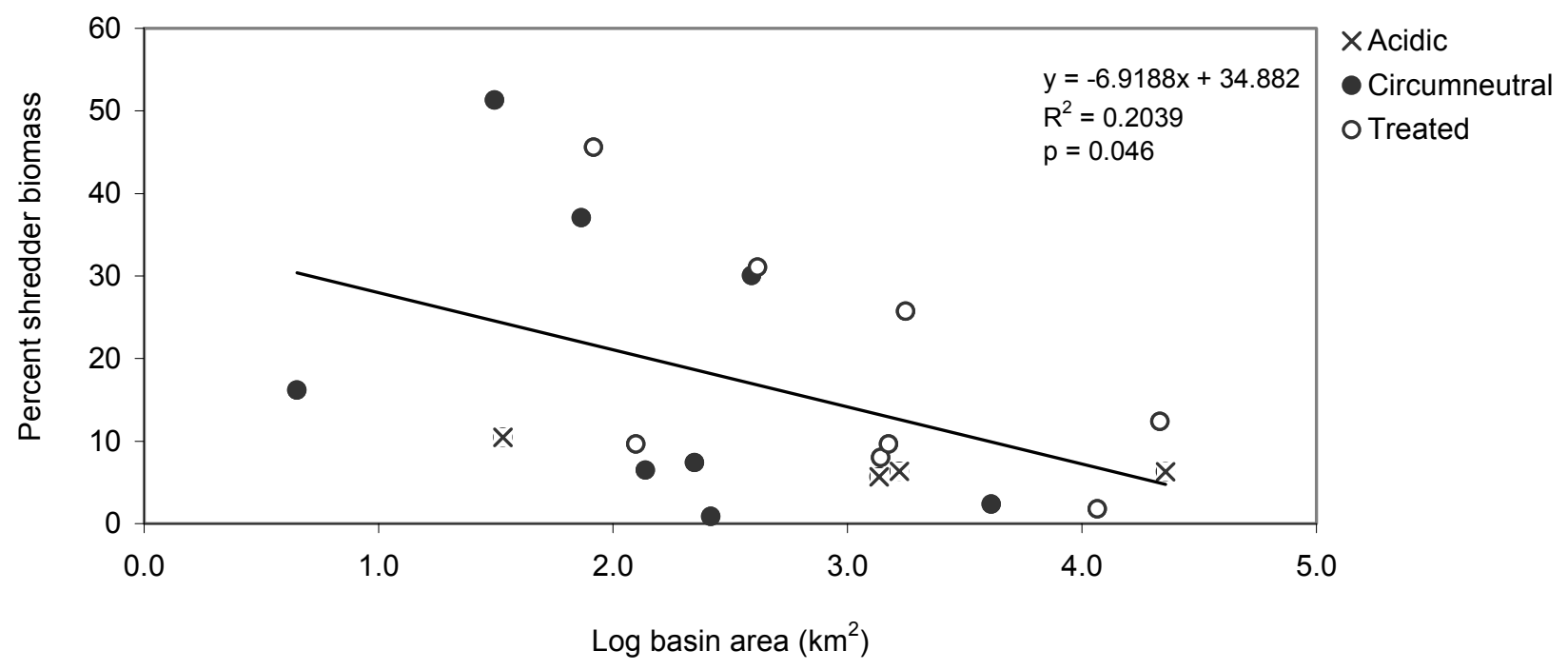

Figure 17. Percent shredder biomass as a function of basin area. A simple linear regression was used to fit a line for all study locals to basin area. 


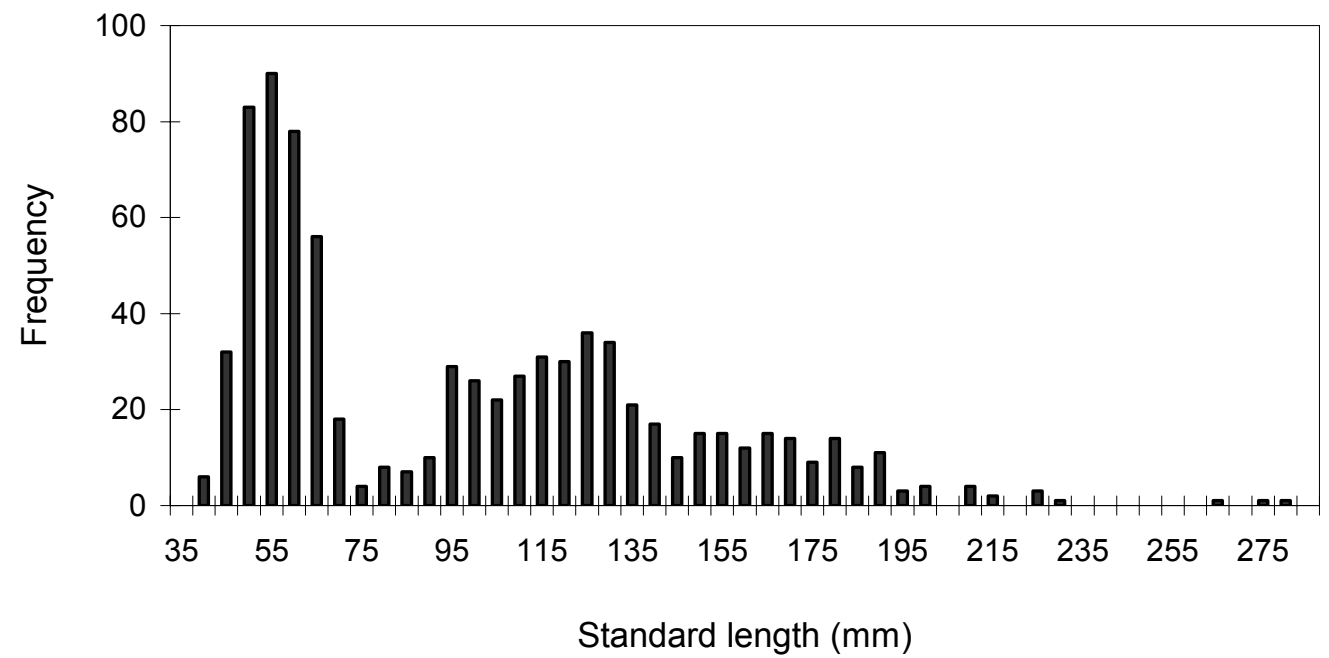

Figure 18. Standard length histogram for all brook trout collected July 2003, WV. 


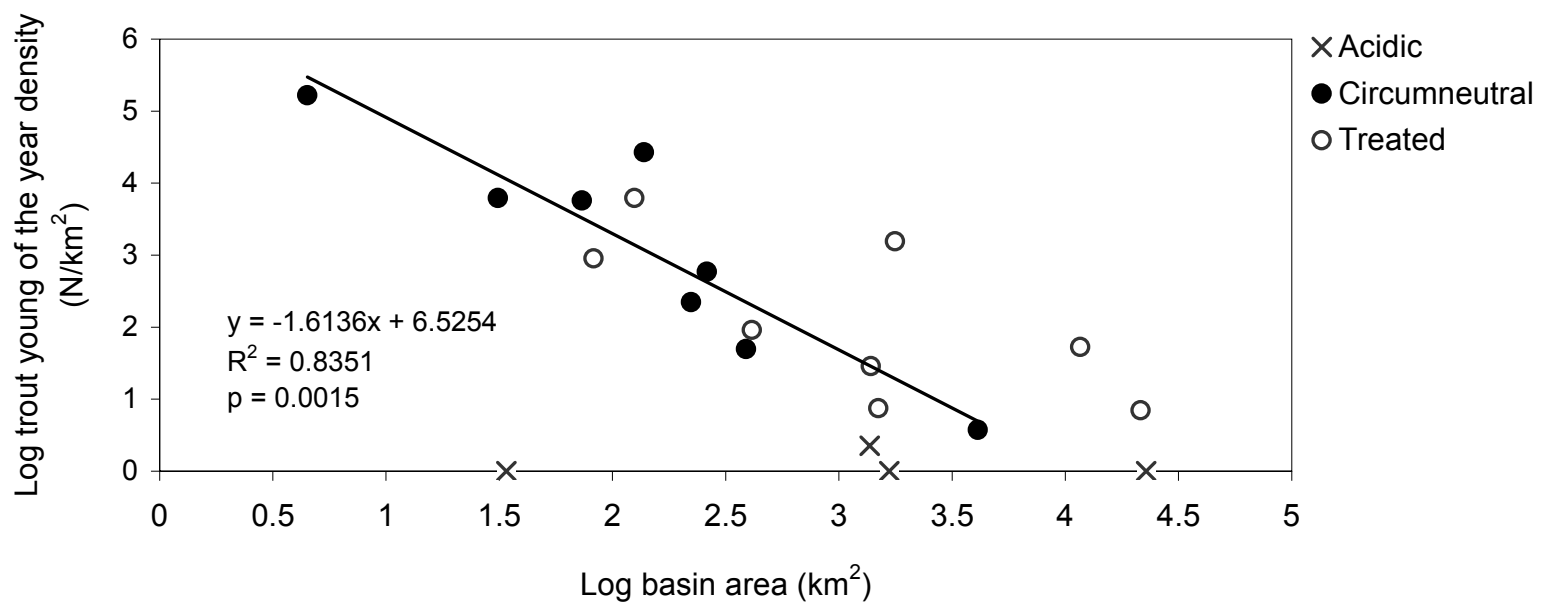

Figure 19. All trout young of the year density as a function of basin area $\left(\mathrm{km}^{2}\right)$. A simple linear regression was used to fit a line to circumneutral streams. 

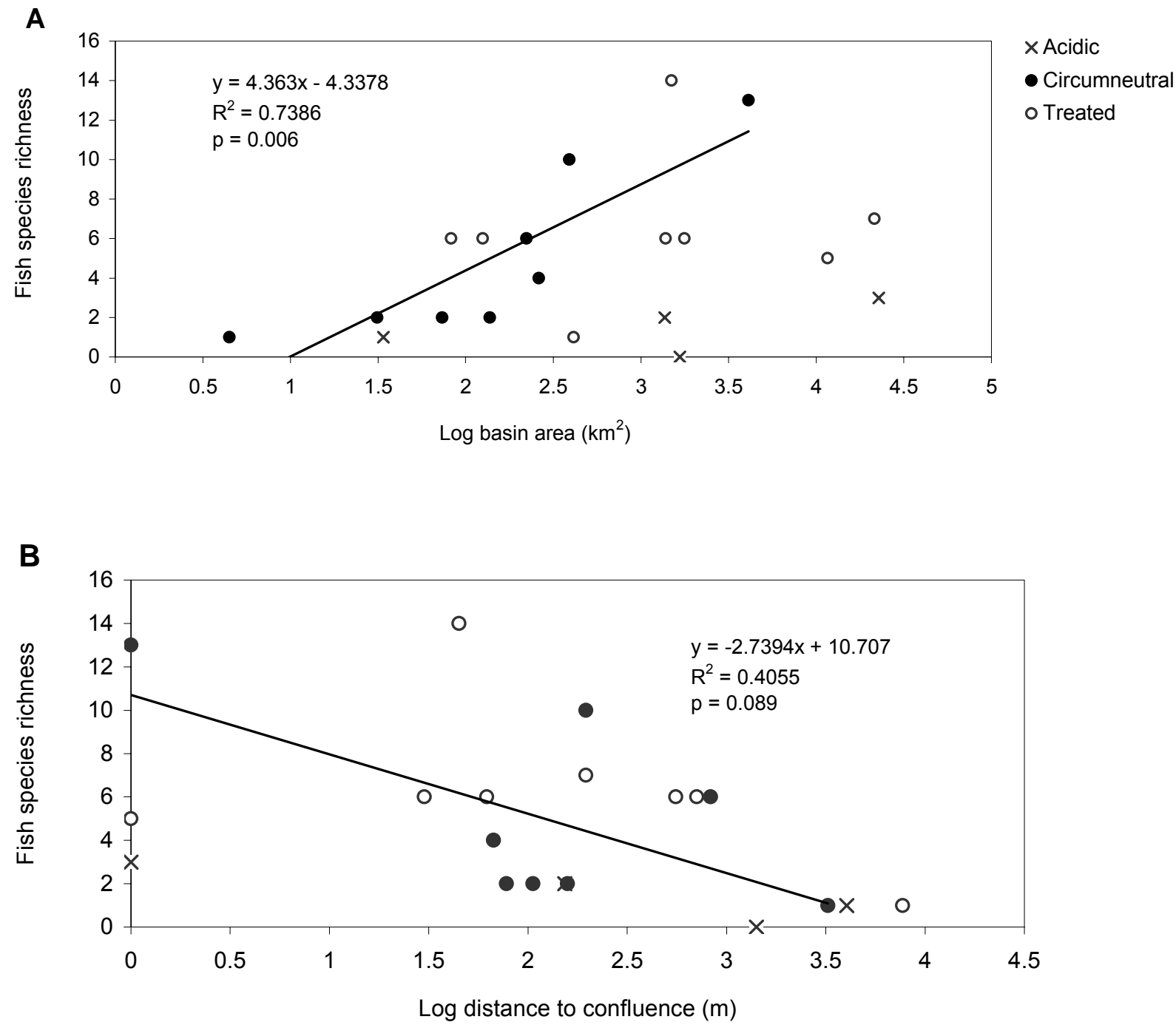

Figure 20. Fish species richness as a function of basin area $\left(\mathrm{km}^{2}\right)$ and distance to mainstem $(m)$. Simple linear regressions were used to fit lines to circumneutral streams. 


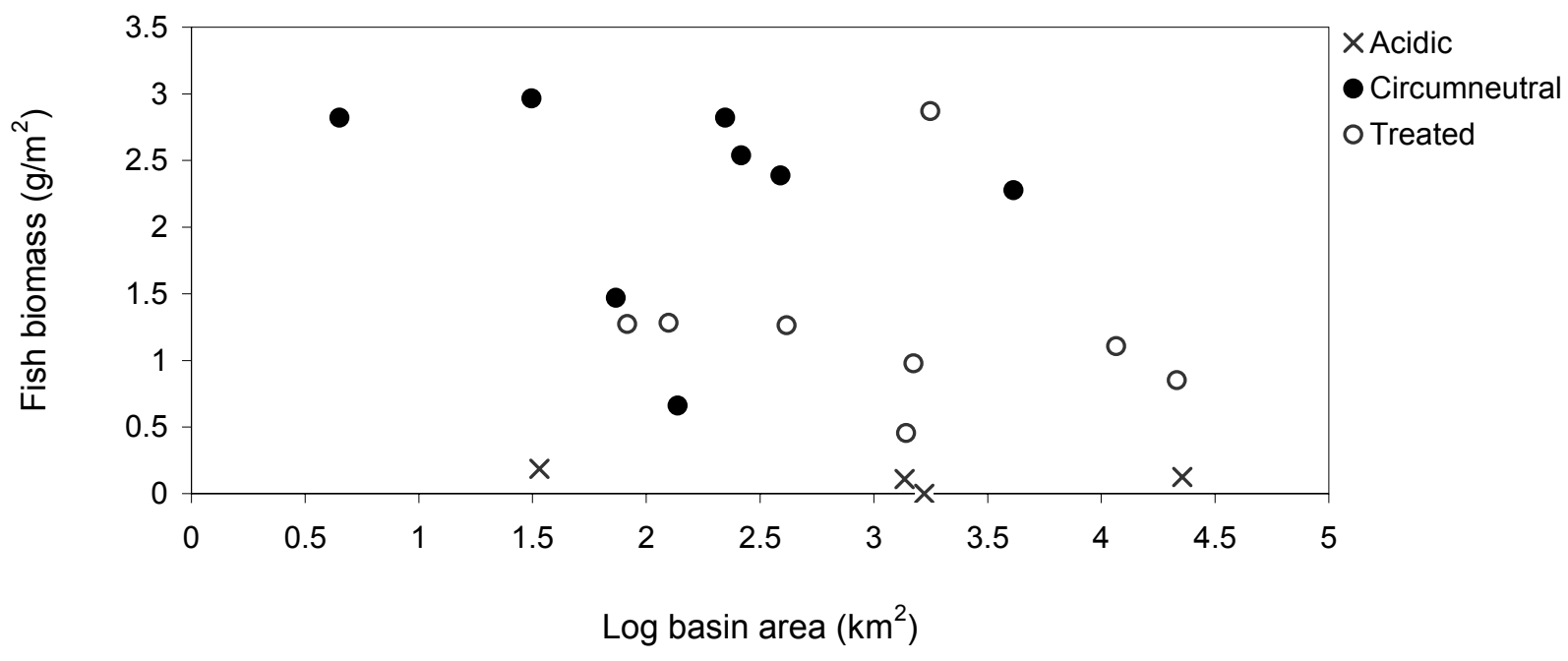

Figure 21. Fish biomass as a function of basin area $\left(\mathrm{km}^{2}\right)$. 
Appendix I. Water chemistry results by sampling period (1-April 2003, 2-September 2003, 3-October 2003, 4-April 2004) and averaged for each study location. Results are in mg/L with the exception of PO4- ( $\mu \mathrm{g} / \mathrm{L})$, conductivity ( $\mu \mathrm{s} / \mathrm{cm})$, temperature $\left({ }^{\circ} \mathrm{C}\right), \mathrm{pH}$ and $\mathrm{Ca}: \mathrm{H}$ ionic ratios.

\begin{tabular}{|c|c|c|c|c|c|c|c|c|c|c|c|c|c|c|c|c|c|c|c|}
\hline Status & Site & $\mathrm{Ca}: \mathrm{H}$ & $\mathrm{pH}$ & Cond & Temp & Alk & $\mathrm{Ca}^{2+}$ & $\mathrm{K}^{2+}$ & $\mathrm{Mg}^{2+}$ & $\mathrm{Na}^{2+}$ & T_Al & D_Al & M_Al & $\mathrm{NO}_{3}{ }^{-}$ & $\mathrm{SO}_{4}{ }^{2-}$ & TP & DP & $\mathrm{PO}_{4}^{-}$ & $\mathrm{Cl}^{-}$ \\
\hline \multirow[t]{6}{*}{$A$} & North Fork Cranberry & & & & & & & & & & & & & & & & & & \\
\hline & 1 & 2.5 & 4.8 & 15 & 10.0 & 3.2 & 0.78 & 0.01 & 0.29 & 0.02 & 0.187 & 0.169 & 0.013 & 0.18 & 4.71 & 0.028 & 0.028 & 0.01 & 1.0 \\
\hline & 2 & 4.7 & 4.8 & 20 & 15.9 & 0.4 & 1.54 & 0.84 & 0.99 & 0.89 & 0.740 & 0.013 & 0.013 & 0.14 & 3.13 & 0.071 & 0.050 & 1.88 & 1.0 \\
\hline & 3 & 42.9 & 6.0 & 18 & 8.7 & 1.8 & 0.84 & 0.15 & 0.35 & 0.20 & 0.097 & 0.082 & 0.013 & 0.02 & 2.69 & 0.028 & 0.028 & 2.94 & 1.0 \\
\hline & 4 & 1.6 & 4.4 & 26 & 7.85 & 1.2 & 1.20 & 0.23 & 0.38 & 0.17 & 0.240 & 0.280 & 0.28 & 0.46 & 3.00 & 0.028 & 0.028 & 2.61 & 1.0 \\
\hline & avg & 12.9 & 5.0 & 20 & 10.6 & 1.6 & 1.09 & 0.31 & 0.50 & 0.32 & 0.316 & 0.136 & 0.080 & 0.20 & 3.38 & 0.040 & 0.034 & 1.86 & 1.0 \\
\hline \multirow[t]{6}{*}{$A$} & Red Creek & & & & & & & & & & & & & & & & & & \\
\hline & 1 & . & . & r & . & . & r & . & . & . & $\cdot$ & . & . & . & . & . & & . & . \\
\hline & 2 & 4.4 & 4.8 & 20 & 14.4 & 2.0 & 1.46 & 0.27 & 0.51 & 0.17 & 0.260 & 0.140 & 0.138 & 0.08 & 3.11 & 0.170 & 0.032 & 3.09 & 1.0 \\
\hline & 3 & 29.7 & 5.7 & 18 & 8.6 & 1.9 & 1.11 & 0.20 & 0.33 & 0.17 & 0.054 & 0.054 & 0.013 & 0.03 & 3.03 & 0.028 & 0.028 & 3.99 & 1.0 \\
\hline & 4 & 3.3 & 4.7 & 21 & 12.92 & 1.6 & 1.25 & 0.29 & 0.35 & 0.14 & 0.085 & 0.070 & 0.013 & 0.19 & 5.20 & 0.035 & 0.028 & 2.67 & 1.0 \\
\hline & avg & 12.5 & 5.1 & 20 & 12.0 & 1.9 & 1.27 & 0.25 & 0.40 & 0.16 & 0.133 & 0.088 & 0.055 & 0.10 & 3.78 & 0.078 & 0.029 & 3.25 & 1.0 \\
\hline \multirow[t]{6}{*}{$A$} & South Fork Red Creek & & & & & & & & & & & & & & & & & & \\
\hline & 1 & 1.7 & 4.5 & 17 & 10.1 & 5.0 & 1.11 & 0.10 & 0.33 & 0.02 & 0.193 & 0.151 & 0.05 & 0.07 & 6.83 & 0.028 & 0.028 & 0.01 & 1.1 \\
\hline & 2 & 3.8 & 4.5 & 28 & 15.7 & 0.8 & 2.38 & 1.07 & 1.32 & 0.94 & 1.100 & 0.250 & 0.07 & 0.17 & 4.05 & 0.092 & 0.028 & 3.11 & 1.0 \\
\hline & 3 & 20.6 & 5.4 & 22 & 9.2 & 1.7 & 1.64 & 0.22 & 0.53 & 0.21 & 0.120 & 0.090 & 0.022 & 0.06 & 4.68 & 0.037 & 0.028 & 3.60 & 1.0 \\
\hline & 4 & 2.7 & 4.6 & 28 & 10 & 1.5 & 1.49 & 0.25 & 0.45 & 0.15 & 0.200 & 0.130 & 0.013 & 0.33 & 4.40 & 0.066 & 0.028 & 1.68 & 1.0 \\
\hline & avg & 7.2 & 4.7 & 24 & 11.2 & 2.2 & 1.66 & 0.41 & 0.66 & 0.33 & 0.403 & 0.155 & 0.039 & 0.16 & 4.99 & 0.060 & 0.028 & 2.10 & 1.0 \\
\hline \multirow[t]{6}{*}{$A$} & Upper Second Fork & & & & & & & & & & & & & & & & & & \\
\hline & 1 & 16.7 & 5.4 & 11 & 5.3 & 0.0 & 1.33 & 0.01 & 0.37 & 0.02 & 0.196 & 0.187 & 0.042 & 0.22 & 5.81 & 0.028 & 0.028 & 0.01 & 1.0 \\
\hline & 2 & 2.8 & 4.7 & 21 & 10.7 & 0.2 & 1.21 & 0.22 & 0.42 & 0.11 & 0.170 & 0.035 & 0.013 & 0.27 & 2.85 & 0.063 & 0.051 & 2.90 & 1.1 \\
\hline & 3 & . & . & . & . & . & . & . & . & . & & . & . & $\cdot$ & . & & & . & $\cdot$ \\
\hline & 4 & 1.1 & 4.3 & 31 & 4.64 & 0.5 & 1.19 & 0.38 & 0.44 & 0.27 & 0.430 & 0.310 & 0.4 & 0.41 & 4.46 & 0.036 & 0.021 & 2.70 & 1.0 \\
\hline & avg & 6.9 & 4.8 & 21 & 6.9 & 0.2 & 1.24 & 0.20 & 0.41 & 0.13 & 0.265 & 0.177 & 0.152 & 0.30 & 4.37 & 0.042 & 0.096 & 1.87 & 1.0 \\
\hline \multirow[t]{6}{*}{$\mathrm{C}$} & Big Run & & & & & & & & & & & & & & & & & & \\
\hline & 1 & 285.1 & 6.7 & 17 & 12.3 & 6.0 & 1.14 & 0.44 & 0.52 & 0.35 & 0.013 & 0.013 & 0.013 & 0.27 & 4.94 & 0.028 & 0.028 & 0.01 & 1.0 \\
\hline & 2 & 243.5 & 6.5 & 23 & 12.5 & 4.1 & 1.44 & 0.54 & 0.70 & 0.28 & 0.013 & 0.013 & 0.013 & 0.30 & 2.86 & 0.067 & 0.046 & 4.81 & 1.0 \\
\hline & 3 & 4514.0 & 7.7 & 7 & 9.9 & 4.3 & 1.89 & 0.76 & 0.81 & 0.42 & 0.013 & 0.013 & 0.013 & 0.21 & 3.56 & 0.100 & 0.039 & 3.65 & 1.1 \\
\hline & 4 & 1080.0 & 7.2 & 23 & 13.75 & 3.2 & 1.43 & 0.63 & 0.61 & 0.47 & 0.013 & 0.013 & 0.013 & 0.33 & 4.51 & 0.028 & 0.028 & 5.32 & 1.0 \\
\hline & avg & 1530.7 & 7.0 & 18 & 12.1 & 4.4 & 1.48 & 0.59 & 0.66 & 0.38 & 0.013 & 0.013 & 0.013 & 0.28 & 3.97 & 0.056 & 0.035 & 3.45 & 1.0 \\
\hline
\end{tabular}


Appendix I. Continued.

\begin{tabular}{|c|c|c|c|c|c|c|c|c|c|c|c|c|c|c|c|c|c|c|c|}
\hline Status & Site & Ca:H & $\mathrm{pH}$ & Cond & Temp & Alk & $\mathrm{Ca}^{2+}$ & $\mathrm{K}^{2+}$ & $\mathrm{Mg}^{2+}$ & $\mathrm{Na}^{2+}$ & T_Al & D_Al & M_Al & $\mathrm{NO}_{3}^{-}$ & $\mathrm{SO}_{4}{ }^{2-}$ & TP & $\mathrm{DP}$ & $\mathrm{PO}_{4}^{-}$ & $\mathrm{Cl}^{-}$ \\
\hline \multirow[t]{6}{*}{$C$} & "Gandy Run & & & & & & & & & & & & & & & & & & \\
\hline & 1 & 104.9 & 6.1 & 17 & 10.7 & 0.0 & 1.67 & 0.27 & 0.58 & 0.90 & 0.029 & 0.013 & 0.013 & 0.30 & 4.90 & 0.028 & 0.028 & 0.01 & 1.0 \\
\hline & 2 & 500.2 & 6.7 & 23 & 15.0 & 3.8 & 2.00 & 0.42 & 0.83 & 0.30 & 0.017 & 0.013 & 0.013 & 0.87 & 3.41 & 0.099 & 0.035 & 3.13 & 1.0 \\
\hline & 3 & 248.9 & 6.5 & 25 & 10.0 & 4.2 & 1.69 & 0.35 & 0.72 & 0.36 & 0.013 & 0.013 & 0.013 & 0.28 & 4.20 & 0.068 & 0.068 & 3.42 & 1.0 \\
\hline & 4 & 2503.5 & 7.4 & 26 & 13.02 & 2.9 & 2.19 & 0.43 & 0.77 & 0.26 & 0.022 & 0.017 & 0.013 & 0.63 & 4.44 & 0.028 & 0.028 & 3.33 & 1.0 \\
\hline & avg & 839.4 & 6.7 & 23 & 12.2 & 2.7 & 1.89 & 0.37 & 0.72 & 0.45 & 0.020 & 0.014 & 0.013 & 0.52 & 4.24 & 0.056 & 0.040 & 2.47 & 1.0 \\
\hline \multirow[t]{6}{*}{ C } & Grants Branch & & & & & & & & & & & & & & & & & & \\
\hline & 1 & 315.3 & 6.7 & 17 & 11.7 & 3.8 & 1.29 & 0.51 & 0.54 & 0.35 & 0.014 & 0.013 & 0.013 & 0.33 & 4.80 & 0.028 & 0.028 & 0.01 & 1.0 \\
\hline & 2 & 259.2 & 6.5 & 24 & 12.3 & 4.2 & 1.72 & 0.67 & 0.75 & 0.45 & 0.013 & 0.013 & 0.013 & 0.42 & 2.62 & 0.065 & 0.028 & 4.71 & 1.0 \\
\hline & 3 & 3233.9 & 7.4 & 25 & 9.3 & & 2.58 & 1.58 & 1.53 & 0.44 & 0.013 & 0.062 & 0.013 & 0.37 & 3.72 & 1.060 & 0.028 & 3.61 & 1.2 \\
\hline & 4 & 1384.5 & 7.3 & 224 & 12.81 & 3.6 & 1.49 & 0.68 & 0.58 & 0.46 & 0.058 & 0.013 & 0.013 & 0.39 & 3.35 & 0.028 & 0.028 & 5.59 & 1.0 \\
\hline & avg & 1298.2 & 7.0 & 73 & 11.5 & 3.9 & 1.77 & 0.86 & 0.85 & 0.42 & 0.025 & 0.025 & 0.013 & 0.38 & 3.62 & 0.295 & 0.028 & 3.48 & 1.1 \\
\hline \multirow[t]{6}{*}{ C } & Jakeman Run & & & & & & & & & & & & & & & & & & \\
\hline & 1 & 836.0 & 6.9 & 20 & 10.3 & 7.9 & 2.26 & 0.29 & 0.68 & 0.02 & 0.013 & 0.013 & 0.013 & 0.43 & 3.54 & 0.028 & 0.028 & 0.01 & 1.0 \\
\hline & 2 & 3100.2 & 7.1 & 45 & 18.7 & 14.2 & 5.05 & 0.58 & 1.18 & 0.26 & 0.013 & 0.013 & 0.013 & 0.34 & 2.17 & 0.049 & 0.028 & 2.89 & 1.0 \\
\hline & 3 & 13702.7 & 8.0 & 33 & 8.9 & 8.0 & 2.81 & 0.42 & 0.85 & 0.24 & 0.013 & 0.013 & 0.013 & 0.23 & 3.08 & 0.061 & 0.061 & 3.77 & 1.0 \\
\hline & 4 & 425.1 & 6.6 & 27 & 10.26 & 4.1 & 2.14 & 0.44 & 0.68 & 0.21 & 0.013 & 0.013 & 0.013 & 0.61 & 3.00 & 0.041 & 0.041 & 3.17 & 1.0 \\
\hline & avg & 4516.0 & 7.1 & 31 & 12.0 & 8.5 & 3.07 & 0.43 & 0.85 & 0.18 & 0.013 & 0.013 & 0.013 & 0.40 & 2.95 & 0.042 & 0.040 & 2.46 & 1.0 \\
\hline \multirow[t]{6}{*}{$\mathrm{C}$} & Little Black Fork & & & & & & & & & & & & & & & & & & \\
\hline & 1 & 9765.1 & 7.5 & 45 & 14.3 & 19.1 & 6.48 & 0.36 & 0.82 & 0.42 & 0.033 & 0.013 & 0.013 & 0.42 & 7.93 & 0.028 & 0.028 & 0.01 & 1.0 \\
\hline & 2 & 1573.1 & 6.6 & 38 & 11.6 & 16.2 & 7.39 & 0.43 & 0.94 & 0.43 & 0.013 & 0.013 & 0.021 & 0.30 & 4.15 & 0.049 & 0.032 & 3.54 & 1.0 \\
\hline & 3 & 2770.6 & 6.9 & 39 & 9.9 & 15.8 & 6.99 & 0.48 & 0.86 & 0.45 & 0.013 & 0.013 & 0.013 & 0.29 & 4.13 & 0.089 & 0.034 & 1.99 & 1.3 \\
\hline & 4 & 187.8 & 5.7 & 24 & 5.03 & 15.4 & 7.17 & 0.46 & 0.89 & 0.47 & 0.033 & 0.017 & 0.013 & 0.58 & 3.28 & 0.063 & 0.063 & 3.98 & 1.0 \\
\hline & avg & 3574.1 & 6.7 & 37 & 10.2 & 16.6 & 7.01 & 0.43 & 0.88 & 0.44 & 0.023 & 0.014 & 0.015 & 0.40 & 4.87 & 0.049 & 0.039 & 2.38 & 1.1 \\
\hline \multirow[t]{6}{*}{ C } & Little Odey & & & & & & & & & & & & & & & & & & \\
\hline & 1 & 204.4 & 6.1 & 38 & & 0.0 & 3.33 & 0.01 & 0.41 & 0.02 & 0.109 & 0.052 & 0.024 & 0.19 & 5.20 & 0.028 & 0.028 & 0.01 & 2.2 \\
\hline & 2 & 3400.4 & 7.1 & 58 & 15.5 & 12.8 & 5.80 & 0.29 & 0.88 & 0.16 & 0.130 & 0.013 & 0.013 & 0.23 & 3.75 & 0.230 & 0.040 & 4.00 & 1.1 \\
\hline & 3 & 6723.4 & 7.5 & 63 & 11.4 & . & 4.36 & 0.20 & 0.55 & 0.12 & 0.038 & 0.013 & 0.013 & 0.10 & 3.88 & 0.087 & 0.028 & 3.00 & 2.8 \\
\hline & 4 & 774.8 & 6.8 & 57 & 12.5 & 3.6 & 2.35 & 0.21 & 0.33 & 0.13 & 0.150 & 0.120 & 0.013 & 0.4 & 5.55 & 0.028 & 0.028 & 2.74 & 1.0 \\
\hline & avg & 2775.7 & 6.9 & 54 & 13.1 & 5.5 & 3.96 & 0.18 & 0.54 & 0.11 & 0.107 & 0.050 & 0.016 & 0.23 & 4.60 & 0.093 & 0.031 & 2.44 & 1.8 \\
\hline
\end{tabular}


Appendix I. Continued.

\begin{tabular}{|c|c|c|c|c|c|c|c|c|c|c|c|c|c|c|c|c|c|c|c|}
\hline Status & Site & Ca:H & $\mathrm{pH}$ & Cond & Temp & Alk & $\mathrm{Ca}^{2+}$ & $\mathrm{K}^{2+}$ & $\mathrm{Mg}^{2+}$ & $\mathrm{Na}^{2+}$ & T_Al & D_Al & M_Al & $\mathrm{NO}_{3}^{-}$ & $\mathrm{SO}_{4}{ }^{2-}$ & TP & DP & $\mathrm{PO}_{4}^{-}$ & $\mathrm{Cl}^{-}$ \\
\hline \multirow[t]{6}{*}{$\bar{C}$} & Rattlesnake & & & & & & & & & & & & & & & & & & \\
\hline & 1 & 13980.9 & 7.5 & 57 & 13.8 & 29.4 & 8.86 & 0.40 & 1.01 & 0.45 & 0.013 & 0.013 & 0.013 & 0.44 & 7.69 & 0.028 & 0.028 & 0.01 & 1.0 \\
\hline & 2 & 4728.4 & 7.0 & 76 & 15.7 & 21.2 & 10.39 & 0.54 & 1.14 & 0.51 & 0.013 & 0.013 & 0.051 & 0.36 & 4.25 & 0.045 & 0.033 & 3.92 & 1.0 \\
\hline & 3 & 16954.7 & 7.5 & 81 & 12.3 & 25.7 & 10.50 & 0.52 & 1.19 & 0.51 & 0.013 & 0.013 & 0.013 & 0.31 & 5.18 & 0.049 & 0.051 & 3.20 & 1.1 \\
\hline & 4 & 7025.9 & 7.1 & 72 & 12.87 & 22.3 & 10.20 & 0.76 & 1.32 & 0.81 & 0.210 & 0.031 & 0.013 & 0.71 & 6.59 & 0.031 & 0.031 & 1.34 & 1.0 \\
\hline & avg & 10672.5 & 7.3 & 72 & 13.7 & 24.6 & 9.99 & 0.56 & 1.17 & 0.57 & 0.062 & 0.018 & 0.022 & 0.46 & 5.93 & 0.038 & 0.106 & 2.12 & 1.0 \\
\hline \multirow[t]{6}{*}{ C } & South Fork Cranberry & & & & & & & & & & & & & & & & & & \\
\hline & 1 & 1070.2 & 6.9 & 23 & 11.7 & 8.4 & 2.70 & 0.11 & 0.52 & 0.56 & 0.052 & 0.013 & 0.013 & 0.17 & 5.55 & 0.028 & 0.028 & 0.01 & 1.4 \\
\hline & 2 & 2866.6 & 7.1 & 45 & 19.0 & 15.2 & 5.12 & 0.35 & 0.96 & 0.96 & 0.013 & 0.013 & 0.013 & 0.23 & 2.68 & 0.067 & 0.028 & 3.44 & 1.3 \\
\hline & 3 & 525.9 & 6.5 & 34 & 8.5 & 9.0 & 3.49 & 0.27 & 0.80 & 0.73 & 0.034 & 0.013 & 0.013 & 0.10 & 2.97 & 0.028 & 0.028 & 4.65 & 1.0 \\
\hline & 4 & 317.7 & 6.3 & 30 & 7.94 & 6.0 & 2.91 & 0.25 & 0.57 & 0.62 & 0.034 & 0.013 & 0.013 & 0.44 & 3.00 & 0.062 & 0.062 & 3.82 & 1.1 \\
\hline & avg & 1195.1 & 6.7 & 33 & 11.8 & 9.7 & 3.56 & 0.24 & 0.71 & 0.72 & 0.033 & 0.013 & 0.013 & 0.23 & 3.55 & 0.038 & 0.037 & 2.98 & 1.2 \\
\hline \multirow[t]{6}{*}{ T } & Big Rocky Run & & & & & & & & & & & & & & & & & & \\
\hline & 1 & 955.3 & 6.9 & 21 & 10.3 & 10.0 & 2.41 & 0.19 & 0.68 & 0.02 & 0.123 & 0.038 & 0.037 & 0.46 & 6.04 & 0.028 & 0.028 & 0.01 & 1.0 \\
\hline & 2 & 729.6 & 6.8 & 28 & 19.1 & 5.6 & 2.60 & 0.49 & 0.90 & 0.75 & 0.094 & 0.013 & 0.013 & 0.14 & 2.71 & 0.130 & 0.028 & 2.68 & 1.0 \\
\hline & 3 & 16805.7 & 8.2 & 30 & 6.5 & 4.8 & 2.33 & 0.36 & 0.84 & 0.21 & 0.045 & 0.015 & 0.013 & 0.17 & 3.03 & 0.065 & 0.054 & 3.44 & 1.0 \\
\hline & 4 & 435.0 & 6.6 & 26 & 8.01 & 2.9 & 2.14 & 0.38 & 0.81 & 0.16 & 0.110 & 0.063 & 0.013 & 0.53 & 5.90 & 0.039 & 0.039 & 2.64 & 1.0 \\
\hline & avg & 4731.4 & 7.1 & 26 & 11.0 & 5.8 & 2.37 & 0.36 & 0.81 & 0.29 & 0.093 & 0.032 & 0.019 & 0.32 & 4.42 & 0.063 & 0.037 & 2.19 & 1.0 \\
\hline \multirow[t]{6}{*}{$T$} & Crouch Run & & & & & & & & & & & & & & & & & & \\
\hline & 1 & 699.0 & 6.8 & 16 & 8.0 & 3.9 & 2.22 & 0.17 & 0.31 & 0.02 & 0.180 & 0.136 & 0.042 & 0.23 & 8.93 & 0.028 & 0.028 & 0.01 & 1.0 \\
\hline & 2 & 694.1 & 6.7 & 25 & 13.3 & 4.6 & 2.84 & 0.22 & 0.43 & 0.15 & 0.088 & 0.018 & 0.013 & 0.16 & 4.56 & 0.074 & 0.028 & 3.27 & 1.3 \\
\hline & 3 & 2327.3 & 7.4 & 24 & 7.6 & 4.0 & 1.90 & 0.26 & 0.39 & 0.13 & 0.083 & 0.043 & 0.014 & 0.14 & 2.42 & 0.052 & 0.040 & 2.65 & 1.0 \\
\hline & 4 & 24.4 & 5.4 & 24 & 8.19 & 2.1 & 1.86 & 0.31 & 0.36 & 0.11 & 0.260 & 0.150 & 0.013 & 0.48 & 3.00 & 0.045 & 0.045 & 2.83 & 1.0 \\
\hline & avg & 936.2 & 6.6 & 22 & 9.3 & 3.6 & 2.21 & 0.24 & 0.37 & 0.10 & 0.153 & 0.087 & 0.021 & 0.25 & 4.73 & 0.046 & 0.035 & 2.19 & 1.1 \\
\hline \multirow[t]{6}{*}{$\begin{array}{ll}\mathrm{T} \\
\end{array}$} & Dogway Fork & & & & & & & & & & & & & & & & & & \\
\hline & 1 & 12793.4 & 7.6 & 34 & 10.3 & 24.4 & 6.44 & 0.01 & 0.29 & 0.02 & 0.155 & 0.136 & 0.051 & 0.20 & 5.90 & 0.028 & 0.028 & 0.01 & 1.2 \\
\hline & 2 & 9170.2 & 7.3 & 52 & 16.8 & 18.4 & 8.40 & 0.23 & 0.47 & 0.12 & 0.055 & 0.013 & 0.048 & 0.12 & 4.25 & 0.076 & 0.028 & 2.65 & 1.0 \\
\hline & 3 & 25087.7 & 7.9 & 50 & 8.8 & 16.0 & 6.94 & 0.19 & 0.40 & 0.16 & 0.072 & 0.044 & 0.013 & 0.11 & 3.84 & 0.028 & 0.028 & 3.65 & 1.0 \\
\hline & 4 & 4087.2 & 7.1 & 44 & 5.42 & 14.3 & 7.30 & 0.27 & 0.44 & 0.14 & 0.210 & 0.210 & 0.013 & 0.38 & 3.27 & 0.063 & 0.063 & 2.84 & 1.0 \\
\hline & avg & 12784.6 & 7.5 & 45 & 10.3 & 18.3 & 7.27 & 0.18 & 0.40 & 0.11 & 0.123 & 0.101 & 0.031 & 0.20 & 4.32 & 0.040 & 0.037 & 2.29 & 1.0 \\
\hline
\end{tabular}


Appendix I. Continued.

\begin{tabular}{|c|c|c|c|c|c|c|c|c|c|c|c|c|c|c|c|c|c|c|c|}
\hline Status & Site & Ca:H & $\mathrm{pH}$ & Cond & Temp & Alk & $\mathrm{Ca}^{2+}$ & $\mathrm{K}^{2+}$ & $\mathrm{Mg}^{2+}$ & $\mathrm{Na}^{2+}$ & T_Al & D_Al & M_Al & $\mathrm{NO}_{3}^{-}$ & $\mathrm{SO}_{4}{ }^{2-}$ & TP & $\mathrm{DP}$ & $\mathrm{PO}_{4}^{-}$ & $\mathrm{Cl}^{-}$ \\
\hline \multirow[t]{6}{*}{$\bar{T}$} & "First Fork & & & & & & & & & & & & & & & & & & \\
\hline & 1 & 151.3 & 6.3 & 12 & 7.3 & 1.7 & 1.52 & 0.12 & 0.34 & 0.02 & 0.175 & 0.118 & 0.017 & 0.20 & 5.67 & 0.028 & 0.028 & 0.01 & 1.0 \\
\hline & 2 & 1079.3 & 6.8 & 26 & 13.3 & 5.9 & 3.35 & 0.31 & 0.59 & 0.14 & 0.013 & 0.013 & 0.013 & 0.15 & 2.97 & 0.160 & 0.063 & 3.02 & 1.0 \\
\hline & 3 & 1203.8 & 7.1 & 24 & 6.5 & 4.4 & 1.83 & 0.21 & 0.43 & 0.19 & 0.043 & 0.026 & 0.013 & 0.17 & 2.90 & 0.035 & 0.028 & 2.93 & 1.0 \\
\hline & 4 & 65.8 & 5.8 & 22 & 5.35 & 2.6 & 1.95 & 0.29 & 0.42 & 0.16 & 0.130 & 0.130 & 0.013 & 0.37 & 3.39 & 0.062 & 0.062 & 2.99 & 1.0 \\
\hline & avg & 625.1 & 6.5 & 21 & 8.1 & 3.7 & 2.16 & 0.23 & 0.44 & 0.13 & 0.090 & 0.072 & 0.014 & 0.22 & 3.73 & 0.063 & 0.045 & 2.24 & 1.0 \\
\hline \multirow[t]{6}{*}{$\mathrm{T}$} & Mcgee Run & & & & & & & & & & & & & & & & & & \\
\hline & 1 & 600.2 & 6.7 & 17 & 8.9 & 5.8 & 2.40 & 0.15 & 0.28 & 0.02 & 0.225 & 0.160 & 0.089 & 0.26 & 5.93 & 0.028 & 0.028 & 0.01 & 1.0 \\
\hline & 2 & 1945.1 & 6.8 & 35 & 13.8 & 9.1 & 5.90 & 0.24 & 0.43 & 0.08 & 0.130 & 0.013 & 0.013 & 0.11 & 2.58 & 0.034 & 0.067 & 5.44 & 1.2 \\
\hline & 3 & 2834.6 & 7.4 & 29 & 7.9 & 5.9 & 2.21 & 0.22 & 0.19 & 0.14 & 0.120 & 0.086 & 0.059 & 0.18 & 1.70 & 0.053 & 0.043 & 2.99 & 1.0 \\
\hline & 4 & 79.9 & 5.8 & 25 & 7.31 & 2.2 & 2.48 & 0.32 & 0.37 & 0.14 & 0.240 & 0.240 & 0.013 & 0.47 & 8.47 & 0.043 & 0.028 & 2.57 & 1.0 \\
\hline & avg & 1365.0 & 6.7 & 27 & 9.5 & 5.8 & 3.25 & 0.23 & 0.32 & 0.10 & 0.179 & 0.125 & 0.044 & 0.26 & 4.67 & 0.040 & 0.042 & 2.75 & 1.0 \\
\hline \multirow[t]{6}{*}{$\mathrm{T}$} & North Fork Cherry River & & & & & & & & & & & & & & & & & & \\
\hline & 1 & 413.4 & 6.5 & 21 & 9.0 & 9.0 & 2.62 & 0.12 & 0.50 & 0.37 & 0.103 & 0.023 & 0.015 & 0.28 & 6.42 & 0.028 & 0.028 & 0.01 & 1.3 \\
\hline & 2 & 3822.8 & 7.2 & 50 & 18.4 & 13.9 & 5.30 & 0.33 & 0.72 & 0.93 & 0.096 & 0.013 & 0.017 & 0.15 & 3.12 & 0.140 & 0.028 & 2.30 & 1.4 \\
\hline & 3 & 16139.3 & 7.9 & 44 & 8.7 & 9.3 & 3.80 & 0.23 & 0.62 & 0.65 & 0.036 & 0.015 & 0.013 & 0.15 & 2.93 & 0.071 & 0.067 & 3.32 & 1.3 \\
\hline & 4 & 949.1 & 6.8 & 35 & 7.09 & 6.0 & 3.23 & 0.27 & 0.50 & 0.95 & 0.150 & 0.130 & 0.013 & 0.52 & 3.00 & 0.042 & 0.042 & 2.84 & 1.8 \\
\hline & avg & 5331.1 & 7.1 & 38 & 10.8 & 9.5 & 3.74 & 0.24 & 0.59 & 0.73 & 0.096 & 0.045 & 0.015 & 0.28 & 3.87 & 0.067 & 0.041 & 2.12 & 1.5 \\
\hline \multirow[t]{6}{*}{$\mathrm{T}$} & Otter Creek & & & & & & & & & & & & & & & & & & \\
\hline & 1 & 300.8 & 6.4 & 17 & 8.6 & 4.2 & 2.40 & 0.01 & 0.31 & 0.02 & 0.168 & 0.091 & 0.06 & 0.09 & 6.17 & 0.028 & 0.028 & 0.01 & 1.0 \\
\hline & 2 & 93.8 & 6.0 & 21 & 15.4 & 2.2 & 2.11 & 0.15 & 0.32 & 0.10 & 0.210 & 0.180 & 0.09 & 0.08 & 3.59 & 0.050 & 0.028 & 2.49 & 1.0 \\
\hline & 3 & 2106.0 & 7.3 & 25 & 9.9 & 3.8 & 2.02 & 0.17 & 0.34 & 0.20 & 0.120 & 0.110 & 0.065 & 0.03 & 2.98 & 0.069 & 0.069 & 3.96 & 1.0 \\
\hline & 4 & 990.9 & 6.9 & 25 & 10.14 & 3.1 & 2.28 & 0.23 & 0.38 & 0.18 & 0.100 & 0.130 & 0.013 & 0.23 & 3.98 & 0.056 & 0.028 & 3.09 & 1.0 \\
\hline & avg & 872.9 & 6.7 & 22 & 11.0 & 3.3 & 2.20 & 0.14 & 0.34 & 0.13 & 0.150 & 0.128 & 0.057 & 0.11 & 4.18 & 0.051 & 0.038 & 2.39 & 1.0 \\
\hline \multirow[t]{6}{*}{$\bar{T}$} & Red Run & & & & & & & & & & & & & & & & & & \\
\hline & 1 & 135.7 & 6.1 & 14 & 8.6 & 3.1 & 2.16 & 0.01 & 0.14 & 0.02 & 0.196 & 0.151 & 0.057 & 0.07 & 6.73 & 0.028 & 0.028 & 0.01 & 1.0 \\
\hline & 2 & 288.0 & 6.3 & 23 & 14.5 & 3.4 & 2.96 & 0.09 & 0.21 & 0.05 & 0.320 & 0.280 & 0.261 & 0.04 & 5.05 & 0.058 & 0.039 & 3.04 & 1.0 \\
\hline & 3 & 555.2 & 6.6 & 23 & 8.9 & 2.6 & 2.86 & 0.11 & 0.43 & 0.14 & 0.170 & 0.170 & 0.11 & 0.03 & 1.80 & 0.028 & 0.028 & 3.76 & 1.0 \\
\hline & 4 & 84.9 & 5.9 & 21 & 9.71 & 2.0 & 2.00 & 0.19 & 0.20 & 0.12 & 0.220 & 0.210 & 0.013 & 0.13 & 3.00 & 0.046 & 0.046 & 3.11 & 1.0 \\
\hline & avg & 266.0 & 6.2 & 20 & 10.4 & 2.8 & 2.50 & 0.10 & 0.24 & 0.08 & 0.227 & 0.203 & 0.110 & 0.07 & 4.14 & 0.036 & 0.035 & 2.48 & 1.0 \\
\hline
\end{tabular}




\section{Appendix II. Acid tolerance classifications for all benthic macroinvertebrate taxa}

collected.

\begin{tabular}{|c|c|c|c|c|c|}
\hline \multicolumn{3}{|l|}{ Acid tolerant taxa } & \multicolumn{3}{|c|}{ Acid sensitive taxa } \\
\hline Order & Family & Genus & Order & Family & Genus \\
\hline$\overline{\text { Diptera }}$ & Ceratopogonidae & . & Ephemeroptera & "Baetidae & Acentrella \\
\hline Diptera & Chironimidae & . & Ephemeroptera & Baetidae & Baetis \\
\hline Diptera & Simuliidae & & Ephemeroptera & Ephemerellidae & Drunella \\
\hline Diptera & Tipulidae & & Ephemeroptera & Ephemerellidae & Ephemerella \\
\hline Ephemeroptera & Ameletidae & Ameletus & Ephemeroptera & Ephemeridae & Ephemera \\
\hline Ephemeroptera & Ephemerellidae & Eurylophella & Ephemeroptera & Leptophlebiidae & Paraleptophlebia \\
\hline Ephemeroptera & Heptageniidae & Epeorus & Plecoptera & Perlidae & Acroneuria \\
\hline Megaloptera & Corydalidae & Nigronia & Plecoptera & Perlidae & Eccoptura \\
\hline Plecoptera & Chloroperlidae & Suwallia & Plecoptera & Pteronarcyidae & Pteronarcys \\
\hline Plecoptera & Chloroperlidae & Sweltsa & Trichoptera & Hydropsychidae & Ceratopsyche \\
\hline Plecoptera & Leuctridae & Leuctra & Trichoptera & Hydropsychidae & Cheumatopsyche \\
\hline Plecoptera & Nemouridae & Amphinemura & Trichoptera & Hydropsychidae & Diplectrona \\
\hline Plecoptera & Nemouridae & Nemoura & Trichoptera & Hydropsychidae & Hydropsyche \\
\hline Plecoptera & Nemouridae & Ostrocerca & Trichoptera & Hydropsychidae & Potamyia \\
\hline Plecoptera & Perlodidae & Isoperla & Trichoptera & Hydroptilidae & Ochrotrichia \\
\hline Plecoptera & Perlodidae & Yugus & Trichoptera & Hydroptilidae & Palaeagapetus \\
\hline Plecoptera & Perlodidae & Diura & Trichoptera & Philopotamidae & Chimarra \\
\hline Plecoptera & Perlodidae & Cultus & Trichoptera & Philopotamidae & Dolophilodes \\
\hline Trichoptera & Hydropsychidae & Parapsyche & & & \\
\hline Trichoptera & Uenoidae & Neophylax & & & \\
\hline Trichoptera & Philopotamidae & Wormaldia & & & \\
\hline Trichoptera & Polycentropodidae & Polycentropus & & & \\
\hline Trichoptera & Rhyacophilidae & Rhyacophila & & & \\
\hline \multicolumn{6}{|c|}{ Tolerance unknown } \\
\hline Order & Family & Genus & & & \\
\hline Coleoptera & Elmidae & - & Trichoptera & Hydropsychidae & $\cdot$ \\
\hline Amphipoda & Gammaridae & . & Trichoptera & Lepidostomatidae & Lepidostoma \\
\hline Coleoptera & Psephenidae & . & Trichoptera & Limnephilidae & Apatania \\
\hline Coleoptera & Ptilodactylidae & Anchytarsus & Trichoptera & Limnephilidae & Goera \\
\hline Coleoptera & Staphylinidae & . & Trichoptera & Philopotamidae & . \\
\hline Diptera & Blephariceridae & . & Trichoptera & Polycentropodidae & Cyrnellus \\
\hline Diptera & Empididae & . & Trichoptera & Polycentropodidae & Paranyctiophylax \\
\hline Diptera & Phoridae & . & Trichoptera & Psychomyiidae & Lype \\
\hline Ephemeroptera & Ephemerellidae & . & & & \\
\hline Ephemeroptera & Heptageniidae & . & & & \\
\hline Ephemeroptera & Heptageniidae & Cinygmula & & & \\
\hline Ephemeroptera & Heptageniidae & Leucrocuta & & & \\
\hline Ephemeroptera & Heptageniidae & Stenacron & & & \\
\hline Ephemeroptera & Heptageniidae & Stenonema & & & \\
\hline Hemiptera & Gerridae & $\cdot$ & & & \\
\hline Hydracarina & Hygrobatoidea & . & & & \\
\hline Hymenoptera & Formicidae & . & & & \\
\hline Megaloptera & Sialidae & Sialis & & & \\
\hline Odonata & Gomphidae & Gomphus & & & \\
\hline Odonata & Libellulidae & . & & & \\
\hline Plecoptera & Peltoperlidae & Tallaperla & & & \\
\hline
\end{tabular}


Appendix III. Benthic macroinvertebrates collected May 2003 from 20 study sites, WV. Life stage: $A=$ adult, $L=$ larvae, $P=$ pupae, $N=$ nymph. Functional Feeding Group (FFG): SHRED = shredder, PRED = predator, UNK = unknown, SCRAP = scraper, GATH = collector/gatherer, FILT = collector/filterer.

\begin{tabular}{|c|c|c|c|c|}
\hline Order & Family & Genus & Life Stage & $\begin{array}{c}\text { Functional } \\
\text { Feeding Group }\end{array}$ \\
\hline Amphipoda & Gammaridae & . & & SHRED \\
\hline Araneae & Araneidae & . & $A$ & PRED \\
\hline Araneae & Lycosidae & . & $A$ & PRED \\
\hline Coleoptera & Carabiidae & . & $A$ & UNK \\
\hline Coleoptera & Curculionidae & . & $A$ & UNK \\
\hline Coleoptera & Elateridae & . & $A$ & UNK \\
\hline Coleoptera & Elmidae & . & $\mathrm{L}$ & SCRAP \\
\hline Coleoptera & Elmidae & . & $A$ & SCRAP \\
\hline Coleoptera & Psephenidae & . & $\mathrm{L}$ & SCRAP \\
\hline Coleoptera & Ptilodactylidae & & $A$ & UNK \\
\hline Coleoptera & Ptilodactylidae & Anchytarsus & $\mathrm{L}$ & SHRED \\
\hline Coleoptera & Staphylinidae & . & $\mathrm{L}$ & PRED \\
\hline Collembola & Isotomidae & . & . & GATH \\
\hline Copepoda & 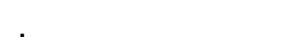 & . & . & UNK \\
\hline Diptera & Blephariceridae & . & L & SCRAP \\
\hline Diptera & Ceratopogonidae & . & $\mathrm{L}$ & PRED \\
\hline Diptera & Ceratopogonidae & . & $P$ & PRED \\
\hline Diptera & Ceratopogonidae & . & $A$ & UNK \\
\hline Diptera & Chironomidae & . & $\mathrm{L}$ & GATH \\
\hline Diptera & Chironomidae & . & $P$ & FILT \\
\hline Diptera & Chironomidae & . & $A$ & UNK \\
\hline Diptera & Drosophilidae & . & $A$ & UNK \\
\hline Diptera & Empididae & . & $\mathrm{L}$ & PRED \\
\hline Diptera & Empididae & . & $P$ & PRED \\
\hline Diptera & Empididae & . & $A$ & PRED \\
\hline Diptera & Phoridae & . & $A$ & UNK \\
\hline Diptera & Simuliidae & . & L & FILT \\
\hline Diptera & Simuliidae & . & $A$ & UNK \\
\hline Diptera & Tipulidae & . & L & GATH \\
\hline Diptera & Tipulidae & . & $\mathrm{P}$ & GATH \\
\hline Ephemeroptera & & & $\mathrm{N}-\mathrm{A}$ & UNK \\
\hline Ephemeroptera & Ameletidae & Ameletus & $\mathrm{N}$ & SCRAP \\
\hline Ephemeroptera & Baetidae & Acentrella & $\mathrm{N}$ & SCRAP \\
\hline Ephemeroptera & Baetidae & Baetis & $\mathrm{N}$ & SCRAP \\
\hline Ephemeroptera & Ephemerellidae & & $\mathrm{N}-\mathrm{A}$ & GATH \\
\hline Ephemeroptera & Ephemerellidae & Drunella & $\mathrm{N}$ & SCRAP \\
\hline Ephemeroptera & Ephemerellidae & Ephemerella & $\mathrm{N}$ & SCRAP \\
\hline Ephemeroptera & Ephemerellidae & Eurylophella & $\mathrm{N}$ & GATH \\
\hline
\end{tabular}




\section{Appendix III. Continued}

\begin{tabular}{|c|c|c|c|c|}
\hline Order & Family & Genus & Life Stage & $\begin{array}{c}\text { Functional } \\
\text { Feeding Group } \\
\end{array}$ \\
\hline Ephemeroptera & Ephemeridae & Ephemera & $\overline{\mathrm{N}}$ & "GATH \\
\hline Ephemeroptera & Heptageniidae & . & $\mathrm{N}-\mathrm{A}$ & SCRAP \\
\hline Ephemeroptera & Heptageniidae & . & $\mathrm{N}$ & SCRAP \\
\hline Ephemeroptera & Heptageniidae & Cinygmula & $\mathrm{N}$ & SCRAP \\
\hline Ephemeroptera & Heptageniidae & Epeorus & $\mathrm{N}$ & GATH \\
\hline Ephemeroptera & Heptageniidae & Heptagenia & $\mathrm{N}$ & SCRAP \\
\hline Ephemeroptera & Heptageniidae & Leucrocuta & $\mathrm{N}$ & SCRAP \\
\hline Ephemeroptera & Heptageniidae & Stenacron & $\mathrm{N}$ & GATH \\
\hline Ephemeroptera & Heptageniidae & Stenonema & $\mathrm{N}$ & SCRAP \\
\hline Ephemeroptera & Isonychiidae & Isonychia & $\mathrm{N}$ & FILT \\
\hline Ephemeroptera & Leptophlebiidae & Paraleptophlebia & $\mathrm{N}$ & GATH \\
\hline Hemiptera & Gerridae & . & $\mathrm{L}$ & PRED \\
\hline Homoptera & Cicadellidae & Coccoidae & $A$ & PIERC \\
\hline Hydracarina & Eylaoidea & . & . & PRED \\
\hline Hydracarina & Hydrachnidia & . & . & PRED \\
\hline Hydracarina & Hygrobatoidea & . & $\mathrm{L}$ & PRED \\
\hline Hymenoptera & Formicidae & . & $\mathrm{L}$ & PARA \\
\hline Lepidoptera & . & . & . & UNK \\
\hline Megaloptera & Chorydalidae & Nigronia & $\mathrm{L}$ & PRED \\
\hline Megaloptera & Sialidae & Sialis & $\mathrm{L}$ & PRED \\
\hline Odonata & Libellulidae & . & $\mathrm{L}$ & PRED \\
\hline Oligocheata & . & . & . & GATH \\
\hline Plecoptera & Chloroperlidae & Suwallia & $\mathrm{N}$ & PRED \\
\hline Plecoptera & Chloroperlidae & Sweltsa & $\mathrm{N}$ & PRED \\
\hline Plecoptera & Leuctridae & Leuctra & $\mathrm{N}$ & SHRED \\
\hline Plecoptera & Nemouridae & Amphinemura & $\mathrm{N}$ & SHRED \\
\hline Plecoptera & Nemouridae & Amphinemura & $A$ & UNK \\
\hline Plecoptera & Nemouridae & Nemoura & $\mathrm{N}$ & SHRED \\
\hline Plecoptera & Nemouridae & Ostrocerca & $\mathrm{N}$ & SHRED \\
\hline Plecoptera & Peltoperlidae & Tallaperla & $\mathrm{N}$ & SHRED \\
\hline Plecoptera & Perlidae & Acroneuria & $\mathrm{N}$ & PRED \\
\hline Plecoptera & Perlidae & Eccoptura & $\mathrm{N}$ & PRED \\
\hline Plecoptera & Perlodidae & Cultus & $\mathrm{N}$ & PRED \\
\hline Plecoptera & Perlodidae & Diura & $\mathrm{N}$ & SCRAP \\
\hline Plecoptera & Perlodidae & Isoperla & $\mathrm{N}$ & PRED \\
\hline Plecoptera & Perlodidae & Yugus & $\mathrm{N}$ & PRED \\
\hline Plecoptera & Pteronarcyidae & Pteronarcys & $\mathrm{N}$ & SHRED \\
\hline Trichoptera & & . & $\mathrm{P}$ & UNK \\
\hline Trichoptera & Hydropsychidae & & $\mathrm{P}$ & FILT \\
\hline
\end{tabular}


Appendix III. Continued.

\begin{tabular}{lllcc}
\hline Order & Family & Genus & Life Stage & $\begin{array}{c}\text { Functional } \\
\text { Feeding Group }\end{array}$ \\
\hline \hline Trichoptera & Hydropsychidae & Ceratopsyche & $\mathrm{L}$ & FILT \\
Trichoptera & Hydropsychidae & Cheumatopsyche & $\mathrm{L}$ & FILT \\
Trichoptera & Hydropsychidae & Diplectrona & $\mathrm{L}$ & FILT \\
Trichoptera & Hydropsychidae & Hydropsyche & $\mathrm{L}$ & FILT \\
Trichoptera & Hydropsychidae & Parapysche & $\mathrm{L}$ & FILT \\
Trichoptera & Hydropsychidae & Potamyia & $\mathrm{L}$ & FILT \\
Trichoptera & Hydroptilidae & Ochrotrichia & $\mathrm{L}$ & GATH \\
Trichoptera & Hydroptilidae & Palaeagapetus & $\mathrm{L}$ & SHRED \\
Trichoptera & Lepidostomatidae & Lepidostoma & $\mathrm{L}$ & SHRED \\
Trichoptera & Limnephilidae & Apatania & $\mathrm{L}$ & SCRAP \\
Trichoptera & Limnephilidae & Goera & $\mathrm{L}$ & SCRAP \\
Trichoptera & Philopotamidae & - & $\mathrm{A}$ & UNK \\
Trichoptera & Philopotamidae & Phimarra & $\mathrm{P}$ & FILT \\
Trichoptera & Philopotamidae & Chima & FILT \\
Trichoptera & Philopotamidae & Dolophilodes & $\mathrm{L}$ & FILT \\
Trichoptera & Philopotamidae & Wormaldia & $\mathrm{L}$ & FILT \\
Trichoptera & Polycentropodidae & Cyrnellus & $\mathrm{L}$ & FILT \\
Trichoptera & Polycentropodidae & Paranyctiophylax & $\mathrm{L}$ & PRED \\
Trichoptera & Polycentropodidae & Polycentropus & $\mathrm{L}$ & PRED \\
Trichoptera & Psychomyiidae & Lype & $\mathrm{L}$ & SCRAP \\
Trichoptera & Rhyacophilidae & Rhyacophila & $\mathrm{L}$ & PRED \\
Trichoptera & Rhyacophilidae & Rhyacophila & $\mathrm{P}$ & PRED \\
Trichoptera & Uenoidae & Neophylax & $\mathrm{L}$ & SCRAP
\end{tabular}


Appendix IV. Percent benthic macroinvertebrate taxa biomass per site.

\begin{tabular}{|c|c|c|c|c|c|}
\hline Site & Status & Order & Family & Genus & $\begin{array}{l}\text { Percent } \\
\text { Biomass }\end{array}$ \\
\hline \multirow[t]{17}{*}{ North Fork Cranberry } & $A$ & Diptera & Ceratopogonidae & 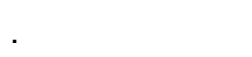 & 0.02 \\
\hline & & Diptera & Chironomidae & . & 4.00 \\
\hline & & Diptera & Simuliidae & . & 2.79 \\
\hline & & Diptera & Tipulidae & & 0.12 \\
\hline & & Ephemeroptera & Ameletidae & Ameletus & 15.89 \\
\hline & & Ephemeroptera & Ephemerellidae & Eurylophella & 1.86 \\
\hline & & Ephemeroptera & Heptageniidae & Epeorus & 3.03 \\
\hline & & Ephemeroptera & Heptageniidae & Stenonema & 0.09 \\
\hline & & Megaloptera & Corydalidae & Nigronia & 2.08 \\
\hline & & Oligocheata & . & & 0.00 \\
\hline & & Plecoptera & Chloroperlidae & Suwallia & 4.92 \\
\hline & & Plecoptera & Leuctridae & Leuctra & 4.89 \\
\hline & & Plecoptera & Nemouridae & Amphinemura & 1.45 \\
\hline & & Plecoptera & Perlodidae & Isoperla & 21.42 \\
\hline & & Trichoptera & Polycentropodidae & Polycentropus & 4.34 \\
\hline & & Trichoptera & Rhyacophilidae & Rhyacophila & 32.73 \\
\hline & & Trichoptera & Uenoidae & Neophylax & 0.37 \\
\hline \multirow[t]{19}{*}{ Red Creek } & $A$ & Coleoptera & Elmidae & . & 0.21 \\
\hline & & Diptera & Ceratopogonidae & . & 0.00 \\
\hline & & Diptera & Chironomidae & . & 30.41 \\
\hline & & Diptera & Empididae & . & 0.00 \\
\hline & & Diptera & Simuliidae & . & 0.32 \\
\hline & & Diptera & Tipulidae & & 1.33 \\
\hline & & Ephemeroptera & Ameletidae & Ameletus & 1.43 \\
\hline & & Ephemeroptera & Ephemerellidae & Eurylophella & 0.10 \\
\hline & & Megaloptera & Corydalidae & Nigronia & 8.80 \\
\hline & & Odonata & Gomphidae & Gomphus & 0.05 \\
\hline & & Oligocheata & . & & 14.41 \\
\hline & & Plecoptera & Chloroperlidae & Suwallia & 0.72 \\
\hline & & Plecoptera & Chloroperlidae & Sweltsa & 10.06 \\
\hline & & Plecoptera & Leuctridae & Leuctra & 5.87 \\
\hline & & Plecoptera & Nemouridae & Amphinemura & 0.41 \\
\hline & & Trichoptera & Hydropsychidae & & 5.17 \\
\hline & & Trichoptera & Hydropsychidae & Parapsyche & 0.43 \\
\hline & & Trichoptera & Polycentropodidae & Polycentropus & 1.87 \\
\hline & & Trichoptera & Rhyacophilidae & Rhyacophila & 18.41 \\
\hline
\end{tabular}


Appendix IV. Continued

\begin{tabular}{|c|c|c|c|c|c|}
\hline Site & Status & Order & Family & Genus & $\begin{array}{l}\text { Percent } \\
\text { Biomass }\end{array}$ \\
\hline \multirow[t]{15}{*}{ South Fork Red Creek } & $A$ & Diptera & Ceratopogonidae & . & 0.01 \\
\hline & & Diptera & Chironomidae & . & 4.64 \\
\hline & & Diptera & Empididae & . & 0.13 \\
\hline & & Diptera & Simuliidae & . & 0.11 \\
\hline & & Diptera & Tipulidae & . & 0.18 \\
\hline & & Ephemeroptera & Ameletidae & Ameletus & 34.04 \\
\hline & & Ephemeroptera & Heptageniidae & Epeorus & 18.30 \\
\hline & & Megaloptera & Corydalidae & Nigronia & 4.36 \\
\hline & & Oligocheata & 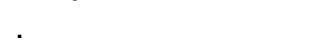 & . & 13.63 \\
\hline & & Plecoptera & Chloroperlidae & Sweltsa & 18.40 \\
\hline & & Plecoptera & Leuctridae & Leuctra & 1.32 \\
\hline & & Plecoptera & Nemouridae & Amphinemura & 0.55 \\
\hline & & Plecoptera & Peltoperlidae & Tallaperla & 3.80 \\
\hline & & Trichoptera & Rhyacophilidae & Rhyacophila & 0.15 \\
\hline & & Trichoptera & Uenoidae & Neophylax & 0.39 \\
\hline \multirow[t]{23}{*}{ Upper Second } & $A$ & Coleoptera & Staphylinidae & . & 0.19 \\
\hline & & Diptera & Ceratopogonidae & . & 0.21 \\
\hline & & Diptera & Chironomidae & . & 2.37 \\
\hline & & Diptera & Simuliidae & . & 0.62 \\
\hline & & Diptera & Tipulidae & . & 0.11 \\
\hline & & Ephemeroptera & Ameletidae & Ameletus & 23.89 \\
\hline & & Ephemeroptera & Ephemerellidae & Eurylophella & 3.89 \\
\hline & & Ephemeroptera & Heptageniidae & & 3.02 \\
\hline & & Ephemeroptera & Heptageniidae & Epeorus & 0.05 \\
\hline & & Hymenoptera & Formicidae & . & \\
\hline & & Megaloptera & Sialidae & Sialis & 1.40 \\
\hline & & Odonata & Gomphidae & Gomphus & 1.00 \\
\hline & & Oligocheata & . & . & 4.91 \\
\hline & & Plecoptera & Leuctridae & Leuctra & 7.53 \\
\hline & & Plecoptera & Nemouridae & Amphinemura & 2.64 \\
\hline & & Plecoptera & Nemouridae & Ostrocerca & 0.32 \\
\hline & & Plecoptera & Perlodidae & Diura & 12.63 \\
\hline & & Plecoptera & Perlodidae & Isoperla & 14.44 \\
\hline & & Trichoptera & Hydropsychidae & Parapsyche & 0.90 \\
\hline & & Trichoptera & Philopotamidae & . & 1.83 \\
\hline & & Trichoptera & Polycentropodidae & Polycentropus & 5.47 \\
\hline & & Trichoptera & Rhyacophilidae & Rhyacophila & 10.35 \\
\hline & & Trichoptera & Uenoidae & Neophylax & 2.24 \\
\hline
\end{tabular}


Appendix IV. Continued.

\begin{tabular}{|c|c|c|c|c|c|}
\hline Site & Status & Order & Family & Genus & $\begin{array}{c}\text { Percent } \\
\text { Biomass }\end{array}$ \\
\hline \multirow[t]{36}{*}{ Big Run } & $\bar{C} \mathrm{C}$ & "Coleoptera & Elmidae & ב. & 0.02 \\
\hline & & Diptera & Blephariceridae & . & 1.89 \\
\hline & & Diptera & Ceratopogonidae & . & 0.00 \\
\hline & & Diptera & Chironomidae & . & 2.62 \\
\hline & & Diptera & Empididae & . & 0.04 \\
\hline & & Diptera & Simuliidae & . & 0.06 \\
\hline & & Diptera & Tipulidae & . & 9.70 \\
\hline & & Ephemeroptera & & . & 0.99 \\
\hline & & Ephemeroptera & Baetidae & Acentrella & 0.24 \\
\hline & & Ephemeroptera & Baetidae & Baetis & 2.44 \\
\hline & & Ephemeroptera & Ephemerellidae & Drunella & 3.46 \\
\hline & & Ephemeroptera & Ephemerellidae & Ephemerella & 4.03 \\
\hline & & Ephemeroptera & Ephemerellidae & Eurylophella & 0.38 \\
\hline & & Ephemeroptera & Heptageniidae & Cinygmula & 4.52 \\
\hline & & Ephemeroptera & Heptageniidae & Epeorus & 11.12 \\
\hline & & Ephemeroptera & Heptageniidae & Leucrocuta & 0.15 \\
\hline & & Ephemeroptera & Heptageniidae & Stenonema & 0.15 \\
\hline & & Ephemeroptera & Leptophlebiidae & Paraleptophlebia & 4.53 \\
\hline & & Megaloptera & Corydalidae & Nigronia & 6.02 \\
\hline & & Odonata & Gomphidae & Gomphus & 1.38 \\
\hline & & Oligocheata & . & . & 0.02 \\
\hline & & Plecoptera & Chloroperlidae & Suwallia & 2.70 \\
\hline & & Plecoptera & Leuctridae & Leuctra & 0.14 \\
\hline & & Plecoptera & Nemouridae & Amphinemura & 0.16 \\
\hline & & Plecoptera & Perlidae & Acroneuria & 19.93 \\
\hline & & Plecoptera & Perlodidae & Diura & 8.27 \\
\hline & & Plecoptera & Perlodidae & Isoperla & 2.24 \\
\hline & & Plecoptera & Pteronarcyidae & Pteronarcys & 0.33 \\
\hline & & Trichoptera & Hydropsychidae & Ceratopsyche & 1.39 \\
\hline & & Trichoptera & Hydropsychidae & Diplectrona & 5.89 \\
\hline & & Trichoptera & Hydropsychidae & Hydropsyche & 0.70 \\
\hline & & Trichoptera & Lepidostomatidae & Lepidostoma & 0.23 \\
\hline & & Trichoptera & Philopotamidae & Dolophilodes & 0.32 \\
\hline & & Trichoptera & Psychomyiidae & Lype & 0.05 \\
\hline & & Trichoptera & Rhyacophilidae & Rhyacophila & 0.70 \\
\hline & & Trichoptera & Uenoidae & Neophylax & 0.28 \\
\hline
\end{tabular}


Appendix IV. Continued.

\begin{tabular}{|c|c|c|c|c|c|}
\hline Site & Status & Order & Family & Genus & $\begin{array}{c}\text { Percent } \\
\text { Biomass }\end{array}$ \\
\hline \multirow[t]{29}{*}{ Gandy Run } & \multirow[t]{29}{*}{$\mathrm{C}$} & Coleoptera & Elmidae & & 0.06 \\
\hline & & Diptera & Ceratopogonidae & & 0.01 \\
\hline & & Diptera & Chironomidae & & 2.81 \\
\hline & & Diptera & Empididae & 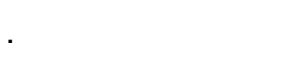 & 0.09 \\
\hline & & Diptera & Simuliidae & & 0.74 \\
\hline & & Diptera & Tipulidae & & 2.21 \\
\hline & & Ephemeroptera & Baetidae & Acentrella & 0.15 \\
\hline & & Ephemeroptera & Baetidae & Baetis & 0.35 \\
\hline & & Ephemeroptera & Ephemerellidae & Drunella & 0.17 \\
\hline & & Ephemeroptera & Ephemerellidae & Ephemerella & 1.87 \\
\hline & & Ephemeroptera & Heptageniidae & Cinygmula & 1.00 \\
\hline & & Ephemeroptera & Heptageniidae & Epeorus & 14.77 \\
\hline & & Ephemeroptera & Heptageniidae & Leucrocuta & 0.47 \\
\hline & & Ephemeroptera & Leptophlebiidae & Paraleptophlebia & 8.16 \\
\hline & & Megaloptera & Corydalidae & Nigronia & 0.04 \\
\hline & & Oligocheata & & & 2.84 \\
\hline & & Plecoptera & Chloroperlidae & Suwallia & 2.86 \\
\hline & & Plecoptera & Chloroperlidae & Sweltsa & 0.73 \\
\hline & & Plecoptera & Leuctridae & Leuctra & 0.10 \\
\hline & & Plecoptera & Nemouridae & Amphinemura & 0.04 \\
\hline & & Plecoptera & Perlidae & Acroneuria & 11.54 \\
\hline & & Plecoptera & Perlodidae & Isoperla & 8.32 \\
\hline & & Plecoptera & Pteronarcyidae & Pteronarcys & 36.91 \\
\hline & & Trichoptera & Hydropsychidae & Ceratopsyche & 0.42 \\
\hline & & Trichoptera & Hydropsychidae & Diplectrona & 2.12 \\
\hline & & Trichoptera & Hydropsychidae & Hydropsyche & 0.30 \\
\hline & & Trichoptera & Hydropsychidae & Potamyia & 0.07 \\
\hline & & Trichoptera & Polycentropodidae & Polycentropus & 0.41 \\
\hline & & Trichoptera & Rhyacophilidae & Rhyacophila & 0.47 \\
\hline \multirow{10}{*}{ Grants Branch } & \multirow{10}{*}{ C } & Amphipoda & Gammaridae & & 0.16 \\
\hline & & Coleoptera & Elmidae & . & 0.09 \\
\hline & & Coleoptera & Ptilodactylidae & & 0.06 \\
\hline & & Coleoptera & Ptilodactylidae & Anchytarsus & 0.01 \\
\hline & & Diptera & Blephariceridae & . & 0.25 \\
\hline & & Diptera & Ceratopogonidae & & 0.12 \\
\hline & & Diptera & Chironomidae & . & 0.72 \\
\hline & & Diptera & Simuliidae & 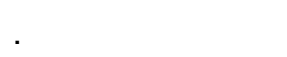 & 0.04 \\
\hline & & Diptera & Tipulidae & & 0.81 \\
\hline & & Ephemeroptera & Baetidae & Baetis & 1.25 \\
\hline
\end{tabular}


Appendix IV. Continued.

\begin{tabular}{|c|c|c|c|c|c|}
\hline Site & Status & Order & Family & Genus & $\begin{array}{c}\text { Percent } \\
\text { Biomass }\end{array}$ \\
\hline \multirow[t]{19}{*}{ Grants Branch } & \multirow[t]{19}{*}{$\mathrm{C}$} & Ephemeroptera & Ephemerellidae & Drunella & 11.21 \\
\hline & & Ephemeroptera & Ephemerellidae & Ephemerella & 3.51 \\
\hline & & Ephemeroptera & Heptageniidae & Cinygmula & 0.21 \\
\hline & & Ephemeroptera & Heptageniidae & Epeorus & 9.70 \\
\hline & & Ephemeroptera & Leptophlebiidae & Paraleptophlebia & 1.54 \\
\hline & & Odonata & Libellulidae & . & 0.03 \\
\hline & & Oligocheata & . & & 3.34 \\
\hline & & Plecoptera & Chloroperlidae & Suwallia & 5.91 \\
\hline & & Plecoptera & Leuctridae & Leuctra & 2.51 \\
\hline & & Plecoptera & Peltoperlidae & Tallaperla & 2.78 \\
\hline & & Plecoptera & Perlidae & Eccoptura & 22.79 \\
\hline & & Plecoptera & Perlodidae & Isoperla & 0.34 \\
\hline & & Plecoptera & Pteronarcyidae & Pteronarcys & 1.17 \\
\hline & & Trichoptera & Hydropsychidae & & 2.87 \\
\hline & & Trichoptera & Hydropsychidae & Ceratopsyche & 1.08 \\
\hline & & Trichoptera & Hydropsychidae & Diplectrona & 9.37 \\
\hline & & Trichoptera & Philopotamidae & Dolophilodes & 1.19 \\
\hline & & Trichoptera & Polycentropodidae & Polycentropus & 3.52 \\
\hline & & Trichoptera & Rhyacophilidae & Rhyacophila & 5.04 \\
\hline \multirow[t]{23}{*}{ Little Black Fork } & \multirow[t]{23}{*}{ C } & Coleoptera & Elmidae & & 0.22 \\
\hline & & Diptera & Blephariceridae & & 0.63 \\
\hline & & Diptera & Ceratopogonidae & . & 0.02 \\
\hline & & Diptera & Chironomidae & . & 5.26 \\
\hline & & Diptera & Simuliidae & . & 0.14 \\
\hline & & Diptera & Tipulidae & . & 0.64 \\
\hline & & Ephemeroptera & Baetidae & Acentrella & 1.15 \\
\hline & & Ephemeroptera & Baetidae & Baetis & 5.44 \\
\hline & & Ephemeroptera & Ephemerellidae & Drunella & 0.88 \\
\hline & & Ephemeroptera & Ephemerellidae & Ephemerella & 0.59 \\
\hline & & Ephemeroptera & Ephemeridae & Ephemera & 1.94 \\
\hline & & Ephemeroptera & Heptageniidae & Cinygmula & 2.52 \\
\hline & & Ephemeroptera & Heptageniidae & Epeorus & 3.53 \\
\hline & & Ephemeroptera & Heptageniidae & Heptagenia & 0.36 \\
\hline & & Ephemeroptera & Heptageniidae & Leucrocuta & 3.35 \\
\hline & & Ephemeroptera & Heptageniidae & Stenacron & 0.25 \\
\hline & & Ephemeroptera & Heptageniidae & Stenonema & 0.12 \\
\hline & & Ephemeroptera & Leptophlebiidae & Paraleptophlebia & 14.11 \\
\hline & & Megaloptera & Corydalidae & Nigronia & 0.28 \\
\hline & & Oligocheata & . & & 4.85 \\
\hline & & Plecoptera & Chloroperlidae & Suwallia & 1.50 \\
\hline & & Plecoptera & Chloroperlidae & Sweltsa & 0.34 \\
\hline & & Plecoptera & Leuctridae & Leuctra & 3.21 \\
\hline
\end{tabular}


Appendix IV. Continued.

\begin{tabular}{|c|c|c|c|c|c|}
\hline Site & Status & Order & Family & Genus & $\begin{array}{l}\text { Percent } \\
\text { Biomass }\end{array}$ \\
\hline \multirow[t]{11}{*}{ Little Black Fork } & $\mathrm{C}$ & Plecoptera & Nemouridae & Amphinemura & 0.06 \\
\hline & & Plecoptera & Peltoperlidae & Tallaperla & 0.03 \\
\hline & & Plecoptera & Perlidae & Acroneuria & 10.70 \\
\hline & & Plecoptera & Perlodidae & Isoperla & 1.08 \\
\hline & & Plecoptera & Pteronarcyidae & Pteronarcys & 26.72 \\
\hline & & Trichoptera & Hydropsychidae & Ceratopsyche & 0.08 \\
\hline & & Trichoptera & Limnephilidae & Apatania & 0.65 \\
\hline & & Trichoptera & Philopotamidae & Dolophilodes & 0.23 \\
\hline & & Trichoptera & Philopotamidae & Wormaldia & 0.00 \\
\hline & & Trichoptera & Polycentropodidae & Polycentropus & 8.99 \\
\hline & & Trichoptera & Rhyacophilidae & Rhyacophila & 0.13 \\
\hline \multirow[t]{31}{*}{ Little Odey } & C & Amphipoda & Gammaridae & . & 0.01 \\
\hline & & Coleoptera & Elmidae & . & 0.82 \\
\hline & & Diptera & Ceratopogonidae & . & 0.04 \\
\hline & & Diptera & Chironomidae & . & 5.32 \\
\hline & & Diptera & Empididae & . & 0.11 \\
\hline & & Diptera & Tipulidae & & 3.14 \\
\hline & & Ephemeroptera & Ameletidae & Ameletus & 0.34 \\
\hline & & Ephemeroptera & Baetidae & Baetis & 0.09 \\
\hline & & Ephemeroptera & Ephemerellidae & Drunella & 0.13 \\
\hline & & Ephemeroptera & Ephemerellidae & Ephemerella & 1.69 \\
\hline & & Ephemeroptera & Ephemeridae & Ephemera & 0.03 \\
\hline & & Ephemeroptera & Heptageniidae & Cinygmula & 4.72 \\
\hline & & Ephemeroptera & Heptageniidae & Epeorus & 3.57 \\
\hline & & Ephemeroptera & Heptageniidae & Stenonema & 4.50 \\
\hline & & Ephemeroptera & Leptophlebiidae & Paraleptophlebia & 0.70 \\
\hline & & Odonata & Gomphidae & Gomphus & 3.19 \\
\hline & & Oligocheata & . & & 0.08 \\
\hline & & Plecoptera & Chloroperlidae & Suwallia & 1.95 \\
\hline & & Plecoptera & Chloroperlidae & Sweltsa & 0.29 \\
\hline & & Plecoptera & Leuctridae & Leuctra & 15.51 \\
\hline & & Plecoptera & Nemouridae & Amphinemura & 0.28 \\
\hline & & Plecoptera & Peltoperlidae & Tallaperla & 0.05 \\
\hline & & Plecoptera & Perlodidae & Isoperla & 5.39 \\
\hline & & Plecoptera & Perlodidae & Yugus & 12.79 \\
\hline & & Plecoptera & Pteronarcyidae & Pteronarcys & 0.05 \\
\hline & & Trichoptera & Hydropsychidae & . & 0.70 \\
\hline & & Trichoptera & Hydropsychidae & Ceratopsyche & 7.98 \\
\hline & & Trichoptera & Hydropsychidae & Cheumatopsyche & 0.18 \\
\hline & & Trichoptera & Hydropsychidae & Parapysche & 4.09 \\
\hline & & Trichoptera & Hydropsychidae & Potamyia & 0.49 \\
\hline & & Trichoptera & Hydroptilidae & Palaeagapetus & 0.04 \\
\hline
\end{tabular}


Appendix IV. Continued.

\begin{tabular}{|c|c|c|c|c|c|}
\hline Site & Status & Order & Family & Genus & $\begin{array}{c}\text { Percent } \\
\text { Biomass }\end{array}$ \\
\hline \multirow[t]{5}{*}{ Little Odey } & \multirow[t]{5}{*}{$\mathrm{C}$} & Trichoptera & Lepidostomatidae & Lepidostoma & 0.24 \\
\hline & & Trichoptera & Philopotamidae & Wormaldia & 0.12 \\
\hline & & Trichoptera & Polycentropodidae & Polycentropus & 3.76 \\
\hline & & Trichoptera & Rhyacophilidae & Rhyacophila & 16.80 \\
\hline & & Trichoptera & Uenoidae & Neophylax & 0.80 \\
\hline \multirow[t]{36}{*}{ Rattlesnake Run } & \multirow[t]{36}{*}{ C } & Coleoptera & Elmidae & . & 0.07 \\
\hline & & Coleoptera & Psephenidae & . & 0.00 \\
\hline & & Diptera & Blephariceridae & . & 0.43 \\
\hline & & Diptera & Ceratopogonidae & . & 0.00 \\
\hline & & Diptera & Chironomidae & . & 4.17 \\
\hline & & Diptera & Empididae & . & 0.00 \\
\hline & & Diptera & Simuliidae & . & 0.07 \\
\hline & & Diptera & Tipulidae & . & 0.16 \\
\hline & & Ephemeroptera & Ameletidae & Ameletus & 0.32 \\
\hline & & Ephemeroptera & Baetidae & Acentrella & 0.17 \\
\hline & & Ephemeroptera & Baetidae & Baetis & 7.83 \\
\hline & & Ephemeroptera & Ephemerellidae & Drunella & 3.27 \\
\hline & & Ephemeroptera & Ephemerellidae & Ephemerella & 0.59 \\
\hline & & Ephemeroptera & Ephemeridae & Ephemera & 5.45 \\
\hline & & Ephemeroptera & Heptageniidae & Cinygmula & 1.10 \\
\hline & & Ephemeroptera & Heptageniidae & Epeorus & 5.50 \\
\hline & & Ephemeroptera & Heptageniidae & Leucrocuta & 1.52 \\
\hline & & Ephemeroptera & Heptageniidae & Stenonema & 1.25 \\
\hline & & Ephemeroptera & Leptophlebiidae & Paraleptophlebia & 5.02 \\
\hline & & Megaloptera & Corydalidae & Nigronia & 9.11 \\
\hline & & Oligocheata & . & . & 3.76 \\
\hline & & Plecoptera & Chloroperlidae & Suwallia & 0.06 \\
\hline & & Plecoptera & Chloroperlidae & Sweltsa & 0.08 \\
\hline & & Plecoptera & Leuctridae & Leuctra & 0.73 \\
\hline & & Plecoptera & Nemouridae & Amphinemura & 0.07 \\
\hline & & Plecoptera & Peltoperlidae & Tallaperla & 0.32 \\
\hline & & Plecoptera & Perlidae & Acroneuria & 36.61 \\
\hline & & Plecoptera & Perlodidae & Isoperla & 2.29 \\
\hline & & Plecoptera & Pteronarcyidae & Pteronarcys & 6.24 \\
\hline & & Trichoptera & Hydropsychidae & Ceratopsyche & 0.55 \\
\hline & & Trichoptera & Hydropsychidae & Cheumatopsyche & 0.07 \\
\hline & & Trichoptera & Hydropsychidae & Hydropsyche & 0.54 \\
\hline & & Trichoptera & Lepidostomatidae & Lepidostoma & 0.01 \\
\hline & & Trichoptera & Philopotamidae & Dolophilodes & 0.04 \\
\hline & & Trichoptera & Polycentropodidae & Polycentropus & 2.34 \\
\hline & & Trichoptera & Rhyacophilidae & Rhyacophila & 0.25 \\
\hline
\end{tabular}


Appendix IV. Continued.

\begin{tabular}{|c|c|c|c|c|c|}
\hline Site & Status & Order & Family & Genus & $\begin{array}{c}\text { Percent } \\
\text { Biomass }\end{array}$ \\
\hline \multirow[t]{38}{*}{ South Fork Cranberry } & $\mathrm{C}$ & Coleoptera & Elmidae & . & 0.16 \\
\hline & & Diptera & Ceratopogonidae & . & 0.06 \\
\hline & & Diptera & Chironomidae & . & 10.48 \\
\hline & & Diptera & Empididae & . & 0.03 \\
\hline & & Diptera & Simuliidae & . & 0.18 \\
\hline & & Diptera & Tipulidae & & 0.25 \\
\hline & & Diptera & Tipulidae & $\cdot$ & 3.34 \\
\hline & & Ephemeroptera & Baetidae & Acentrella & 1.61 \\
\hline & & Ephemeroptera & Baetidae & Baetis & 1.52 \\
\hline & & Ephemeroptera & Ephemerellidae & . & 0.17 \\
\hline & & Ephemeroptera & Ephemerellidae & Drunella & 3.55 \\
\hline & & Ephemeroptera & Ephemerellidae & Ephemerella & 1.08 \\
\hline & & Ephemeroptera & Ephemerellidae & Eurylophella & 0.28 \\
\hline & & Ephemeroptera & Ephemeridae & Ephemera & 0.40 \\
\hline & & Ephemeroptera & Heptageniidae & 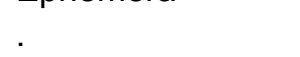 & 0.15 \\
\hline & & Ephemeroptera & Heptageniidae & Epeorus & 2.60 \\
\hline & & Ephemeroptera & Heptageniidae & Leucrocuta & 0.06 \\
\hline & & Ephemeroptera & Heptageniidae & Stenonema & 4.50 \\
\hline & & Ephemeroptera & Isonychiidae & Isonychia & 0.26 \\
\hline & & Ephemeroptera & Leptophlebiidae & Paraleptophlebia & 2.45 \\
\hline & & Hydracarina & Hygrobatoidea & . & \\
\hline & & Megaloptera & Corydalidae & Nigronia & 8.84 \\
\hline & & Oligocheate & . & . & 4.14 \\
\hline & & Plecoptera & Chloroperlidae & Suwallia & 0.46 \\
\hline & & Plecoptera & Chloroperlidae & Sweltsa & 0.02 \\
\hline & & Plecoptera & Leuctridae & Leuctra & 1.96 \\
\hline & & Plecoptera & Nemouridae & Amphinemura & 0.04 \\
\hline & & Plecoptera & Peltoperlidae & Tallaperla & 0.36 \\
\hline & & Plecoptera & Perlidae & Acroneuria & 42.56 \\
\hline & & Plecoptera & Perlodidae & Isoperla & 1.63 \\
\hline & & Trichoptera & . & . & 0.28 \\
\hline & & Trichoptera & Hydropsychidae & Ceratopsyche & 2.81 \\
\hline & & Trichoptera & Hydropsychidae & Cheumatopsyche & 0.31 \\
\hline & & Trichoptera & Hydroptilidae & Ochrotrichia & 0.00 \\
\hline & & Trichoptera & Philopotamidae & Chimarra & 0.84 \\
\hline & & Trichoptera & Philopotamidae & Dolophilodes & 1.10 \\
\hline & & Trichoptera & Philopotamidae & Wormaldia & 0.17 \\
\hline & & Trichoptera & Polycentropodidae & Polycentropus & 1.33 \\
\hline
\end{tabular}


Appendix IV. Continued.

\begin{tabular}{|c|c|c|c|c|c|}
\hline Site & Status & Order & Family & Genus & $\begin{array}{c}\text { Percent } \\
\text { Biomass }\end{array}$ \\
\hline \multirow[t]{23}{*}{ Big Rocky Run } & $\mathrm{T}$ & Diptera & Ceratopogonidae & & 0.09 \\
\hline & & Diptera & Chironomidae & & 10.67 \\
\hline & & Diptera & Empididae & . & 0.01 \\
\hline & & Diptera & Simuliidae & . & 0.24 \\
\hline & & Diptera & Tipulidae & & 0.92 \\
\hline & & Ephemeroptera & Ameletidae & Ameletus & 1.32 \\
\hline & & Ephemeroptera & Baetidae & Baetis & 18.50 \\
\hline & & Ephemeroptera & Ephemerellidae & Ephemerella & 5.35 \\
\hline & & Ephemeroptera & Heptageniidae & Cinygmula & 0.86 \\
\hline & & Ephemeroptera & Heptageniidae & Epeorus & 4.03 \\
\hline & & $\begin{array}{l}\text { Ephemeroptera } \\
\text { Hemiptera }\end{array}$ & $\begin{array}{l}\text { Heptageniidae } \\
\text { Gerridae }\end{array}$ & Stenonema & 12.11 \\
\hline & & Oligocheata & . & & 0.06 \\
\hline & & Plecoptera & Chloroperlidae & Suwallia & 10.89 \\
\hline & & Plecoptera & Leuctridae & Leuctra & 3.48 \\
\hline & & Plecoptera & Nemouridae & Amphinemura & 0.21 \\
\hline & & Plecoptera & Perlidae & Acroneuria & 1.14 \\
\hline & & Plecoptera & Perlodidae & Isoperla & 7.81 \\
\hline & & Trichoptera & Hydropsychidae & & 1.08 \\
\hline & & Trichoptera & Hydropsychidae & Ceratopsyche & 6.61 \\
\hline & & Trichoptera & Hydropsychidae & Diplectrona & 1.64 \\
\hline & & Trichoptera & Lepidostomatidae & Lepidostoma & 4.33 \\
\hline & & Trichoptera & Polycentropodidae & Polycentropus & 0.31 \\
\hline & & Trichoptera & Rhyacophilidae & Rhyacophila & 8.35 \\
\hline \multirow[t]{13}{*}{ Crouch Run } & $\mathrm{T}$ & Diptera & Chironomidae & & 12.84 \\
\hline & & Ephemeroptera & Ameletidae & Ameletus & 11.90 \\
\hline & & Ephemeroptera & Ephemerellidae & Eurylophella & 50.06 \\
\hline & & Oligocheata & r & & 3.18 \\
\hline & & Plecoptera & Chloroperlidae & Suwallia & 0.35 \\
\hline & & Plecoptera & Leuctridae & Leuctra & 6.97 \\
\hline & & Plecoptera & Nemouridae & & 1.06 \\
\hline & & Plecoptera & Nemouridae & Amphinemura & 1.62 \\
\hline & & Plecoptera & Nemouridae & Ostrocerca & 0.00 \\
\hline & & Plecoptera & Perlodidae & Isoperla & 1.01 \\
\hline & & Trichoptera & Polycentropodidae & Paranyctiophylax & 6.83 \\
\hline & & Trichoptera & Polycentropodidae & Polycentropus & 0.92 \\
\hline & & Trichoptera & Rhyacophilidae & Rhyacophila & 3.26 \\
\hline
\end{tabular}


Appendix IV. Continued.

\begin{tabular}{|c|c|c|c|c|c|}
\hline Site & Status & Order & Family & Genus & $\begin{array}{l}\text { Percent } \\
\text { Biomass }\end{array}$ \\
\hline \multirow[t]{34}{*}{ Dogway Fork } & $\mathrm{T}$ & Coleoptera & Elmidae & & 0.01 \\
\hline & & Diptera & Ceratopogonidae & & 1.13 \\
\hline & & Diptera & Chironomidae & . & 4.07 \\
\hline & & Diptera & Empididae & . & 0.00 \\
\hline & & Diptera & Simuliidae & . & 0.00 \\
\hline & & Diptera & Tipulidae & & 0.14 \\
\hline & & Ephemeroptera & Baetidae & Acentrella & 0.90 \\
\hline & & Ephemeroptera & Baetidae & Baetis & 2.25 \\
\hline & & Ephemeroptera & Ephemerellidae & Drunella & 3.64 \\
\hline & & Ephemeroptera & Ephemerellidae & Ephemerella & 0.05 \\
\hline & & Ephemeroptera & Heptageniidae & Epeorus & 6.16 \\
\hline & & Ephemeroptera & Heptageniidae & Stenonema & 4.12 \\
\hline & & Ephemeroptera & Leptophlebiidae & Paraleptophlebia & 2.71 \\
\hline & & Megaloptera & Corydalidae & Nigronia & 3.06 \\
\hline & & Oligocheata & . & & 33.44 \\
\hline & & Plecoptera & Chloroperlidae & Suwallia & 0.41 \\
\hline & & Plecoptera & Chloroperlidae & Sweltsa & 0.28 \\
\hline & & Plecoptera & Leuctridae & Leuctra & 0.23 \\
\hline & & Plecoptera & Nemouridae & Amphinemura & 0.03 \\
\hline & & Plecoptera & Peltoperlidae & Tallaperla & 0.00 \\
\hline & & Plecoptera & Perlidae & Acroneuria & 1.20 \\
\hline & & Plecoptera & Perlodidae & Isoperla & 0.07 \\
\hline & & Plecoptera & Pteronarcyidae & Pteronarcys & 25.25 \\
\hline & & Trichoptera & Hydropsychidae & & 3.66 \\
\hline & & Trichoptera & Hydropsychidae & Ceratopsyche & 0.52 \\
\hline & & Trichoptera & Hydropsychidae & Hydropsyche & 0.16 \\
\hline & & Trichoptera & Hydroptilidae & Ochrotrichia & 0.01 \\
\hline & & Trichoptera & Lepidostomatidae & Lepidostoma & 0.24 \\
\hline & & Trichoptera & Limnephilidae & Goera & 1.46 \\
\hline & & Trichoptera & Philopotamidae & Dolophilodes & 1.16 \\
\hline & & Trichoptera & Polycentropodidae & Cyrnellus & 0.15 \\
\hline & & Trichoptera & Polycentropodidae & Polycentropus & 2.76 \\
\hline & & Trichoptera & Rhyacophilidae & Rhyacophila & 0.65 \\
\hline & & Trichoptera & Uenoidae & Neophylax & 0.06 \\
\hline
\end{tabular}


Appendix IV. Continued.

\begin{tabular}{|c|c|c|c|c|c|}
\hline Site & Status & Order & Family & Genus & $\begin{array}{c}\text { Percent } \\
\text { Biomass }\end{array}$ \\
\hline \multirow[t]{16}{*}{ First Fork } & $\mathrm{T}$ & Coleoptera & Elmidae & . & 0.02 \\
\hline & & Diptera & Ceratopogonidae & . & 1.41 \\
\hline & & Diptera & Chironomidae & . & 8.07 \\
\hline & & Diptera & Empididae & . & 0.00 \\
\hline & & Diptera & Simuliidae & . & 0.09 \\
\hline & & Diptera & Tipulidae & . & 3.27 \\
\hline & & Ephemeroptera & Heptageniidae & Stenonema & 10.56 \\
\hline & & Megaloptera & Corydalidae & Nigronia & 4.98 \\
\hline & & Plecoptera & Chloroperlidae & Suwallia & 4.45 \\
\hline & & Plecoptera & Leuctridae & Leuctra & 3.36 \\
\hline & & Plecoptera & Nemouridae & Amphinemura & 0.27 \\
\hline & & Plecoptera & Peltoperlidae & Tallaperla & 6.02 \\
\hline & & Plecoptera & Perlidae & Acroneuria & 4.48 \\
\hline & & Trichoptera & Hydropsychidae & Hydropsyche & 2.01 \\
\hline & & Trichoptera & Polycentropodidae & Polycentropus & 46.12 \\
\hline & & Trichoptera & Rhyacophilidae & Rhyacophila & 4.87 \\
\hline \multirow[t]{15}{*}{ McGee Run } & $\mathrm{T}$ & Diptera & Chironomidae & . & 4.70 \\
\hline & & Diptera & Phoridae & . & 1.46 \\
\hline & & Diptera & Simuliidae & . & 1.61 \\
\hline & & Ephemeroptera & Ameletidae & Ameletus & 12.70 \\
\hline & & Ephemeroptera & Heptageniidae & Epeorus & 0.37 \\
\hline & & Ephemeroptera & Heptageniidae & Leucrocuta & 3.36 \\
\hline & & Oligocheata & & . & 2.83 \\
\hline & & Plecoptera & Chloroperlidae & Suwallia & 3.19 \\
\hline & & Plecoptera & Chloroperlidae & Sweltsa & 11.13 \\
\hline & & Plecoptera & Leuctridae & Leuctra & 12.27 \\
\hline & & Plecoptera & Nemouridae & Amphinemura & 26.68 \\
\hline & & Trichoptera & Hydropsychidae & Potamyia & 1.93 \\
\hline & & Trichoptera & Lepidostomatidae & Lepidostoma & 6.64 \\
\hline & & Trichoptera & Polycentropodidae & Polycentropus & 3.26 \\
\hline & & Trichoptera & Rhyacophilidae & Rhyacophila & 7.88 \\
\hline
\end{tabular}


Appendix IV. Continued.

\begin{tabular}{|c|c|c|c|c|c|}
\hline Site & Status & Order & Family & Genus & $\begin{array}{c}\text { Percent } \\
\text { Biomass }\end{array}$ \\
\hline \multirow[t]{24}{*}{ North Fork Cherry } & $\mathrm{T}$ & Coleoptera & Elmidae & . & 0.22 \\
\hline & & Diptera & Ceratopogonidae & . & 0.03 \\
\hline & & Diptera & Chironomidae & . & 5.14 \\
\hline & & Diptera & Simuliidae & . & 1.60 \\
\hline & & Diptera & Tipulidae & . & 0.63 \\
\hline & & Ephemeroptera & Baetidae & Baetis & 13.98 \\
\hline & & Ephemeroptera & Ephemerellidae & Drunella & 0.34 \\
\hline & & Ephemeroptera & Ephemerellidae & Ephemerella & 0.17 \\
\hline & & Ephemeroptera & Heptageniidae & Cinygmula & 0.16 \\
\hline & & Ephemeroptera & Heptageniidae & Epeorus & 14.84 \\
\hline & & Ephemeroptera & Heptageniidae & Leucrocuta & 5.25 \\
\hline & & Ephemeroptera & Heptageniidae & Stenonema & 17.75 \\
\hline & & Ephemeroptera & Leptophlebiidae & Paraleptophlebia & 12.59 \\
\hline & & Megaloptera & Corydalidae & Nigronia & 2.25 \\
\hline & & Oligocheata & & & 0.41 \\
\hline & & Plecoptera & Chloroperlidae & Suwallia & 8.31 \\
\hline & & Plecoptera & Leuctridae & Leuctra & 1.79 \\
\hline & & Plecoptera & Perlidae & Acroneuria & 1.52 \\
\hline & & Trichoptera & Hydropsychidae & Ceratopsyche & 0.78 \\
\hline & & Trichoptera & Hydropsychidae & Hydropsyche & 7.19 \\
\hline & & Trichoptera & Hydropsychidae & Potamyia & 0.39 \\
\hline & & Trichoptera & Philopotamidae & Dolophilodes & 0.52 \\
\hline & & Trichoptera & Rhyacophilidae & Rhyacophila & 3.48 \\
\hline & & Trichoptera & Uenoidae & Neophylax & 0.67 \\
\hline \multirow[t]{16}{*}{ Otter Creek } & $\mathrm{T}$ & Diptera & Ceratopogonidae & . & 0.00 \\
\hline & & Diptera & Chironomidae & . & 2.66 \\
\hline & & Diptera & Empididae & . & 0.00 \\
\hline & & Diptera & Simuliidae & . & 0.47 \\
\hline & & Diptera & Tipulidae & . & 1.30 \\
\hline & & Ephemeroptera & Ephemerellidae & Drunella & 0.54 \\
\hline & & Ephemeroptera & Ephemerellidae & Ephemerella & 3.63 \\
\hline & & Ephemeroptera & Heptageniidae & Cinygmula & 0.07 \\
\hline & & Ephemeroptera & Heptageniidae & Epeorus & 3.79 \\
\hline & & Ephemeroptera & Heptageniidae & Leucrocuta & 0.13 \\
\hline & & Megaloptera & Corydalidae & Nigronia & 0.14 \\
\hline & & Oligocheata & & 然 & 17.74 \\
\hline & & Plecoptera & Chloroperlidae & Suwallia & 4.67 \\
\hline & & Plecoptera & Chloroperlidae & Sweltsa & 2.96 \\
\hline & & Plecoptera & Leuctridae & Leuctra & 12.22 \\
\hline & & Plecoptera & Nemouridae & Amphinemura & 0.19 \\
\hline
\end{tabular}


Appendix IV. Continued.

\begin{tabular}{|c|c|c|c|c|c|}
\hline Site & Status & Order & Family & Genus & $\begin{array}{c}\text { Percent } \\
\text { Biomass }\end{array}$ \\
\hline \multirow[t]{4}{*}{ Otter Creek } & $T$ & Plecoptera & Perlidae & Acroneuria & 46.53 \\
\hline & & Trichoptera & Hydroptilidae & Ochrotrichia & 0.00 \\
\hline & & Trichoptera & Polycentropodidae & Polycentropus & 2.25 \\
\hline & & Trichoptera & Rhyacophilidae & Rhyacophila & 0.71 \\
\hline \multirow[t]{16}{*}{ Red Run } & $\mathrm{T}$ & Diptera & Ceratopogonidae & . & 0.02 \\
\hline & & Diptera & Chironomidae & . & 3.77 \\
\hline & & Diptera & Tipulidae & . & 0.17 \\
\hline & & Ephemeroptera & Ameletidae & Ameletus & 19.45 \\
\hline & & Ephemeroptera & Heptageniidae & Epeorus & 20.75 \\
\hline & & Oligocheata & . & 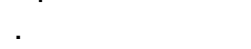 & 2.48 \\
\hline & & Plecoptera & Chloroperlidae & Suwallia & 1.27 \\
\hline & & Plecoptera & Leuctridae & Leuctra & 15.93 \\
\hline & & Plecoptera & Nemouridae & Amphinemura & 8.55 \\
\hline & & Plecoptera & Nemouridae & Ostrocerca & 0.42 \\
\hline & & Trichoptera & Hydropsychidae & & 1.59 \\
\hline & & Trichoptera & Hydropsychidae & Hydropsyche & 1.63 \\
\hline & & Trichoptera & Hydropsychidae & Parapsyche & 5.01 \\
\hline & & Trichoptera & Lepidostomatidae & Lepidostoma & 6.15 \\
\hline & & Trichoptera & Polycentropodidae & Polycentropus & 1.36 \\
\hline & & Trichoptera & Rhyacophilidae & Rhyacophila & 11.45 \\
\hline
\end{tabular}

